Werner Weiss | Franz Mauthner

\title{
SOLAR HEAT WORLDWIDE
}

Markets and Contribution to the Energy Supply 2008

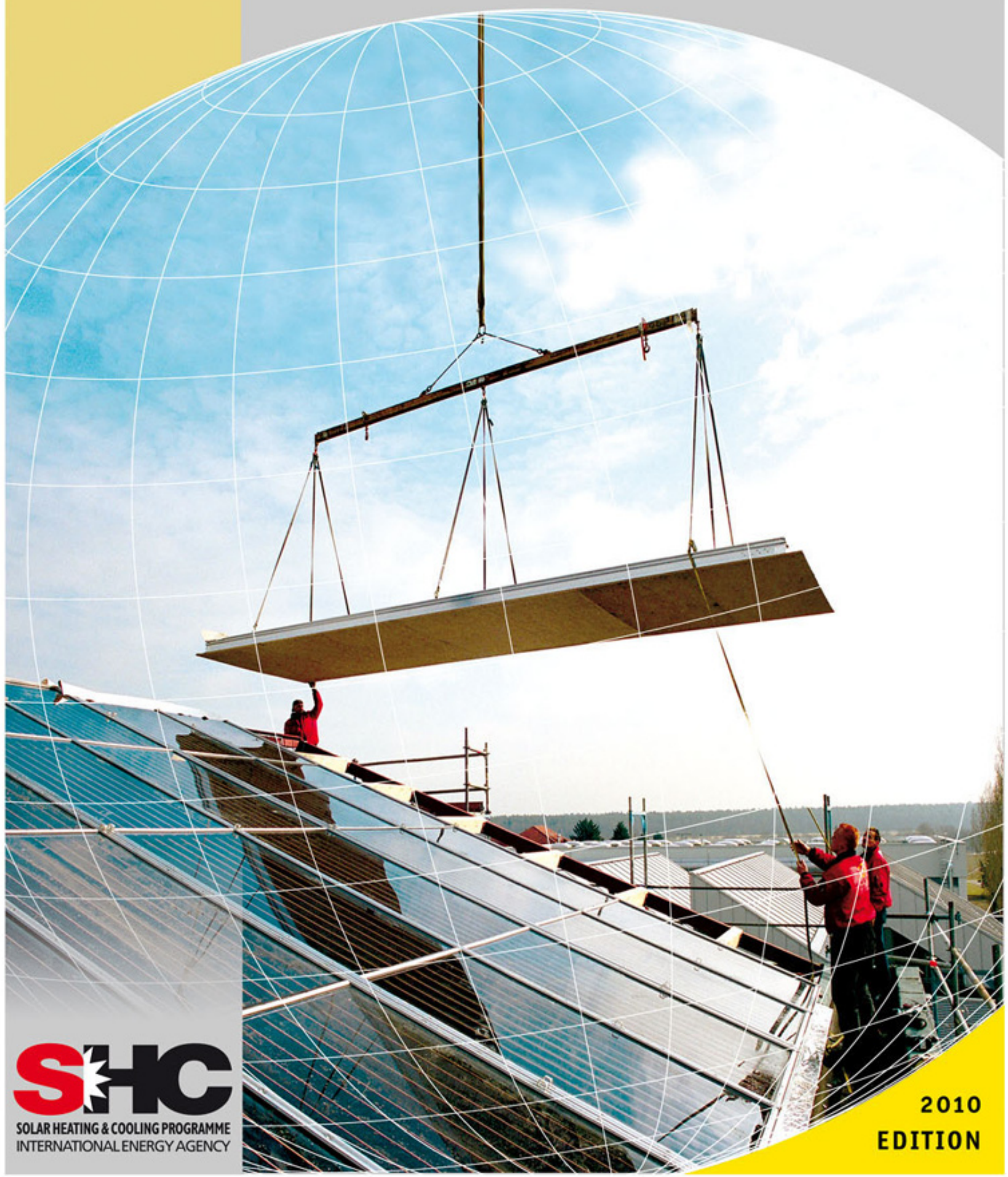




\title{
SOLAR HEAT WORLDWIDE
}

Markets and Contribution to the Energy Supply 2008

EDITION 2010

\author{
Werner Weiss | Franz Mauthner
}

AEE INTEC

AEE - Institute for Sustainable Technologies

A-8200 Gleisdorf, Austria

IEA Solar Heating \& Cooling Programme, May 2010

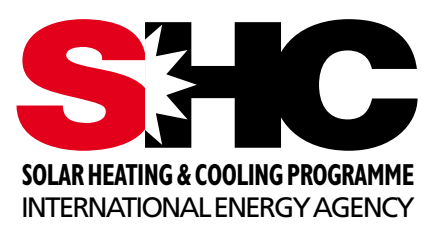

Supported by the Austrian Ministry for Transport, Innovation and Technology

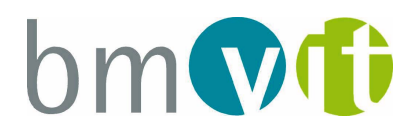

Design, Grafics, Typesetting \& Imageprocessing: STEINHUBER INFODESIGN, Graz, Austria Cover photo source: Pfeil \& Koch Ingenieurgesellschaft GmbH \&Co KG, Stuttgart

Notice:

The Solar Heating and Cooling Programme functions within a framework created by the International Energy Agency (IEA). Views, findings and publications of the Solar Heating and Cooling Programme do not necessarily represent the views or policies of the IEA Secretariat or of all its individual member countries. 


\section{Table of Contents}

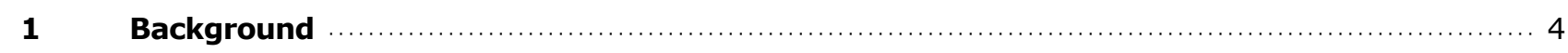

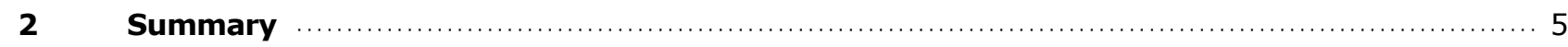

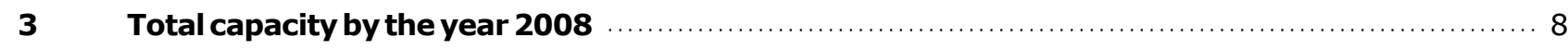

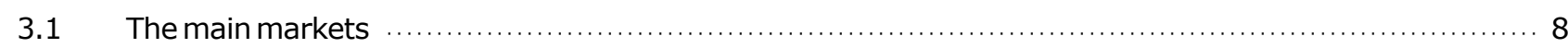

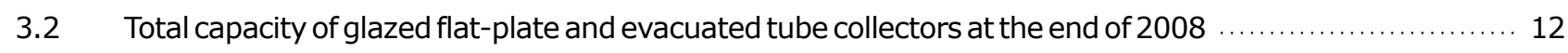

3.3 Total capacity of glazed flat-plate and evacuated tube collectors

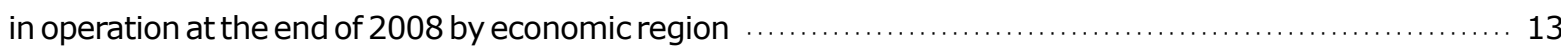

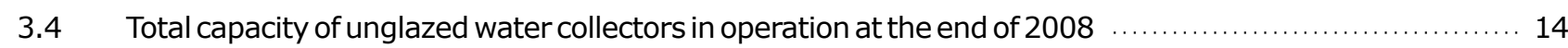

3.5 Total capacity of unglazed water collectors in operation

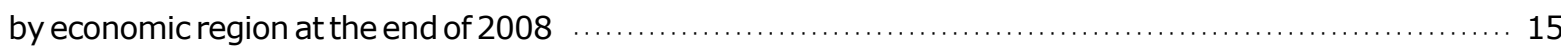

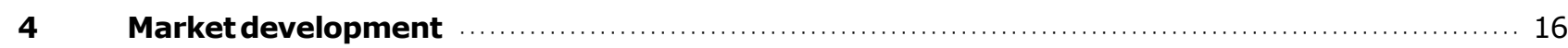

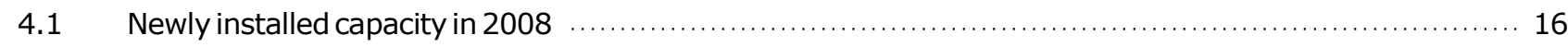

4.2 Market development of glazed flat-plate and evacuated tube collectors by economic region .............. 20

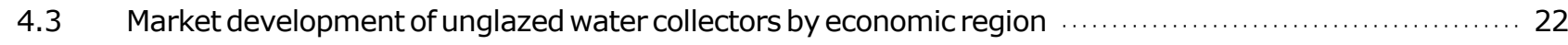

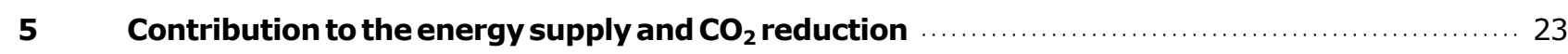

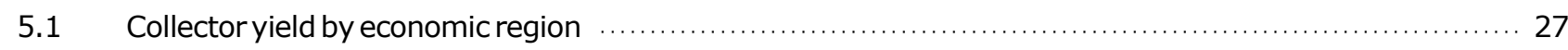

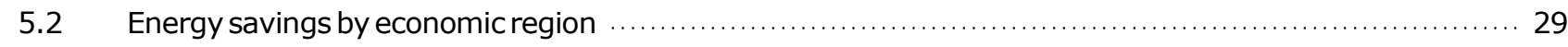

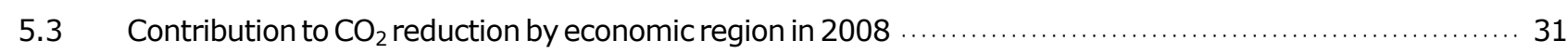

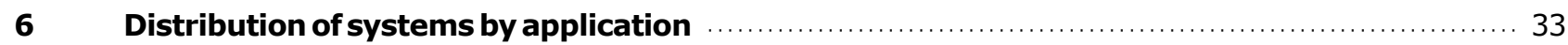

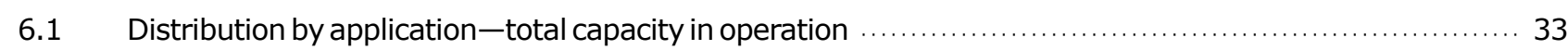

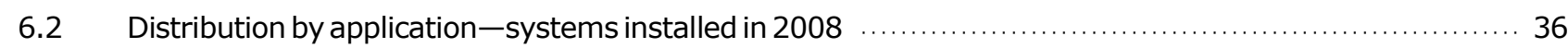

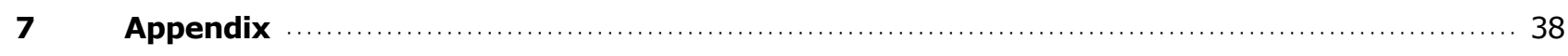

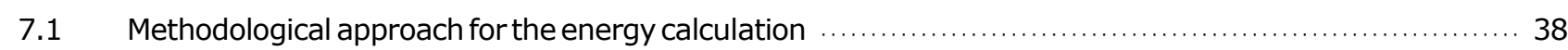

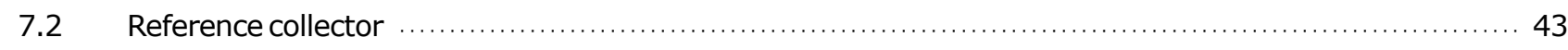

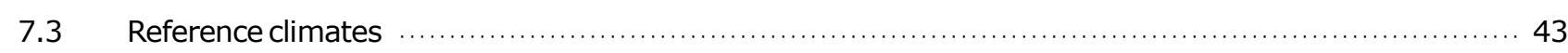

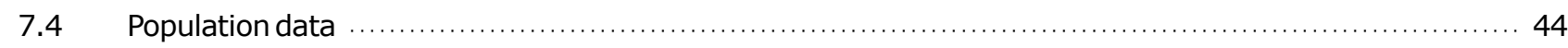

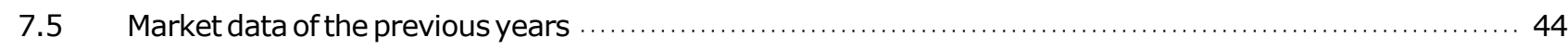

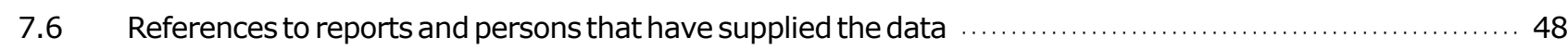

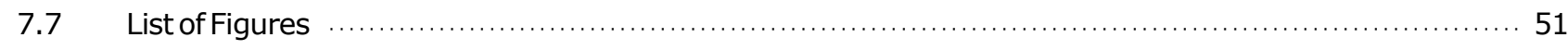

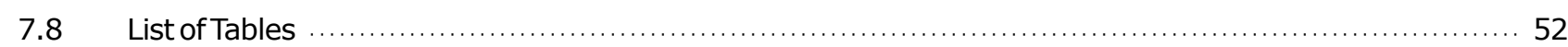




\section{$1 \quad$ Background}

This report was prepared within the framework of the Solar Heating and Cooling Programme (SHC) of the International Energy Agency (IEA). The goal of the report is to document the solar thermal capacity previously installed in the important markets worldwide, and to ascertain the contribution of solar thermal systems to the supply of energy and the $\mathrm{CO}_{2}$ emissions avoided as a result of operating these systems. The collectors documented are unglazed collectors, glazed flat-plate and evacuated tube collectors with water as the energy carrier as well as glazed and unglazed air collectors.

The data were collected from a questionnaire survey of the national delegates of the SHC Programme's Executive Committee and other national experts active in the field of solar thermal energy. Since some of the 53 countries included in this report have very detailed statistics and others could only provide estimates from experts, the data was checked for its plausibility on the basis of various publications.

Starting with the collector area respectively the capacity installed, the contributions of solar thermal systems towards the supply of energy and the reduction of $\mathrm{CO}_{2}$ were ascertained.

The 53 countries included in this report represent 4.1 billion people, which is about $61 \%$ of the world's population. The installed capacity in these countries is estimated to represent $85-90 \%$ of the solar thermal market worldwide.

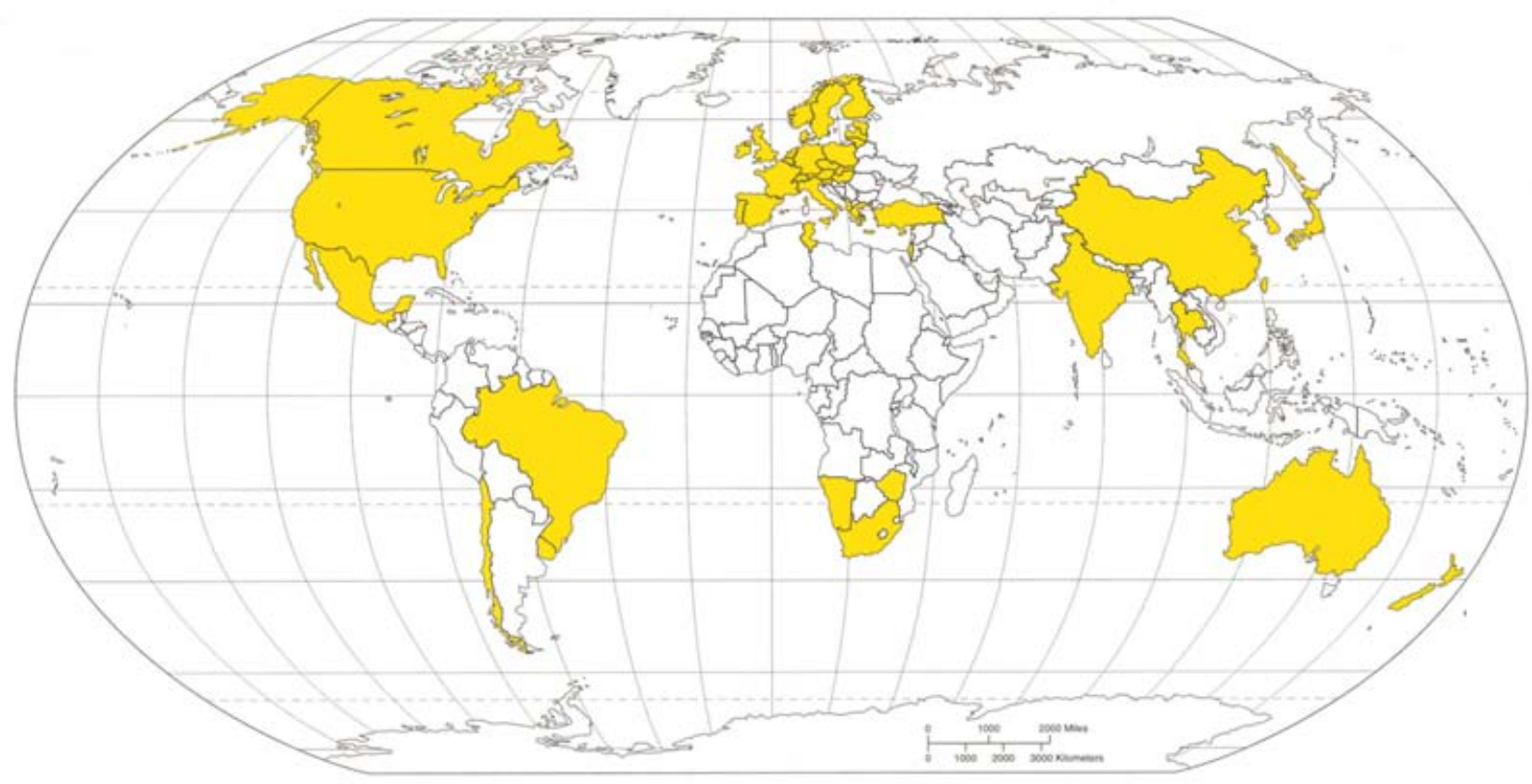

Figure 1: Countries represented in this report 


\section{Summary}

\section{Solar Thermal Capacity in Operation Worldwide}

The solar thermal collector capacity in operation worldwide equaled $151.7 \mathrm{GW}_{\text {th }}$ corresponding to 217.0 million square meters ${ }^{1}$ by the end of the year 2008 . Of this, $131.8 \mathrm{GW}_{\text {th }}$ were accounted for by flat-plate and evacuated tube collectors and $18.9 \mathrm{GW}_{\text {th }}$ for unglazed plastic collectors. Air collector capacity was installed to an extent of $1.2 \mathrm{GW}_{\text {th }}$.

The main markets are in China (87.5 GW $\mathrm{GW}_{\text {th }}$ ), Europe $\left(28.5 \mathrm{GW}_{\text {th }}\right)$, and the United States and Canada (15.1 $\left.\mathrm{GW}_{\text {th }}\right)$ which together account for $86.3 \%$ of the total installations. The rest of the market is shared between Japan (4.42 $\mathrm{GW}_{\text {th }}$ ), Australia and New Zealand (4.36 GW $\mathrm{th}_{\text {th }}$ ), some Asian countries (4.02 $\left.\mathrm{GW}_{\text {th }}\right)$, Central and South American countries ( $\left.3.8 \mathrm{GW}_{\mathrm{th}}\right)$, the Middle East represented by Israel and Jordan ( $3.29 \mathrm{GW}_{\mathrm{th}}$ ) and some African countries $\left(0.9 \mathrm{GW}_{\mathrm{th}}\right)$.

\section{Distribution by Application}

The use of solar thermal energy varies greatly in the different countries. In China, Europe and Japan, the dominant systems are flat-plate and evacuated tube collectors, which are primarily used to prepare hot water and to provide space heating. In other large markets, such as the United States and Australia, unglazed plastic absorbers for swimming pool heating are the dominant application.

The dominant collector type is the vacuum tube collector, which represents $54.2 \%$ of the global market, followed by the flat-plate collector with a market share of $32.6 \%$. Unglazed plastic collectors account for $12.4 \%$ of the market and air collectors represent the smallest share with $0.8 \%$.

Besides China and Jordan, where evacuated tube collectors dominate the market, in all the other documented countries the flat plate collector remains the dominant collector type. However, there is a notable trend in the growing market share of evacuated tube collectors in Germany, Italy, Poland, the United States, the United Kingdom and Spain. And, in South Africa and Sweden evacuated tube collectors have nearly reached similar market shares to flat plate collectors.

Another distinction that can be made pertains to pumped solar systems and thermosiphon systems. In the United States, Europe and Australia pumped solar thermal systems are primarily installed. In other large markets, namely in Japan, Brazil and China, thermosiphon systems are predominant.

Europe has the most sophisticated market for offering a diverse selection of solar thermal applications. It includes systems for hot water preparation, plants for space heating of single- and multi-family houses and hotels, large-scale plants for district heating as well as a growing number of systems for industrial applications and for air conditioning and cooling.

There are about 150 large-scale plants $\left(\geq 500 \mathrm{~m}^{2} ; 350 \mathrm{~kW}_{\mathrm{th}}\right)$ in operation in Europe with a total installed capacity of $160 \mathrm{MW}_{\text {th }}$. The biggest plants for solar assisted district heating are located in Denmark with $13 \mathrm{MW}_{\text {th }}\left(18,300 \mathrm{~m}^{2}\right)$ and Sweden with $7 \mathrm{MW}_{\text {th }}\left(10,000 \mathrm{~m}^{2}\right)$. The largest reported solar thermal system for industrial process heat was installed in 2007 in China. The $9 \mathrm{MW}_{\mathrm{th}}\left(13,000 \mathrm{~m}^{2}\right)$ plant produces heat for a textile company.

\section{Leading Countries}

Flat-plate and evacuated tube collectors

In terms of the total capacity in operation of flat-plate and evacuated tube collectors at the end of the year 2008, China (87.5 GW $\left.\mathrm{Gh}_{\text {th }}\right)$, Turkey $\left(7.5 \mathrm{GW}_{\text {th }}\right)$, Germany $\left(7.2 \mathrm{GW}_{\text {th }}\right)$, Japan $\left(4.1 \mathrm{GW}_{\text {th }}\right)$ and Greece (2.7 GW $\left.\mathrm{Gh}_{\text {th }}\right)$ are the leading

\footnotetext{
1 Making the installed capacity of solar thermal collectors comparable with that of other energy sources, solar thermal experts from seven countries agreed upon a methodology to convert installed collector area into solar thermal capacity at a joint meeting of the IEA SHC Programme and major solar thermal trade associations held September 2004 in Gleisdorf, Austria. The represented associations from Austria, Canada, Germany, the Netherlands, Sweden and United States as well as the European Solar Thermal Industry Federation (ESTIF) and the IEA SHC Programme agreed to use a factor of $0.7 \mathrm{~kW}$ th $/ \mathrm{m}^{2}$ to derive the nominal capacity from the area of installed collectors.
} 
countries. They are followed by Israel (2.6 GW $\left.\mathrm{Gh}_{\text {th }}\right)$, Brazil $\left(2.4 \mathrm{GW}_{\mathrm{th}}\right)$, Austria $\left(2.3 \mathrm{GW}_{\mathrm{th}}\right)$, the United States (1.9 $\left.\mathrm{GW}_{\mathrm{th}}\right)$ and India $\left(1.8 \mathrm{GW}_{\mathrm{th}}\right)$.

China is by far the largest market, representing $66.4 \%$ of the world market for flat-plate and evacuated tube collectors.

In terms of market penetration, based on the total capacity in operation per 1,000 inhabitants, Cyprus ( $527.2 \mathrm{~kW}_{\mathrm{th}}$ ), Israel $\left(371.3 \mathrm{~kW}_{\text {th }}\right)$, Austria $\left(285.0 \mathrm{~kW}_{\text {th }}\right)$, Greece $\left(252.6 \mathrm{~kW}_{\text {th }}\right)$ and Barbados $\left(202.7 \mathrm{~kW}_{\text {th }}\right)$ are the leading countries. They are followed by Jordan (101.9 kW th $)$, Turkey $\left(98.2 \mathrm{~kW}_{\text {th }}\right)$, Germany $\left(87.7 \mathrm{~kW}_{\mathrm{th}}\right)$, Australia $\left(66.6 \mathrm{~kW}_{\mathrm{th}}\right)$ and China $\left(66.4 \mathrm{~kW}_{\text {th }}\right)$.

Unglazed plastic collectors

With regard to the heating of swimming pools with unglazed plastic collectors, the United States lead with a total capacity of $12.4 \mathrm{GW}_{\text {th }}$ in operation ahead of Australia with $2.9 \mathrm{GW}_{\mathrm{th}}$, Brazil with $0.6 \mathrm{GW}_{\mathrm{th}}$, Germany, Canada and South Africa with around $0.5 \mathrm{GW}_{\text {th }}$ each, and Austria with $0.4 \mathrm{GW}_{\text {th }}$.

The market penetration gives a slightly different picture-Australia leads in installed capacity per 1,000 inhabitants with $136.6 \mathrm{~kW}_{\text {th }}$ ahead of Austria with $53.2 \mathrm{~kW}_{\text {th }}$ and the United States with $40.8 \mathrm{~kW}_{\text {th }}$. In fourth to sixth place are Switzerland, Canada and the Netherlands with installed capacities between 20 and $15 \mathrm{~kW}_{\text {th }}$ per 1,000 inhabitants.

\section{Installed Capacity in 2008}

In the year 2008, a new capacity of $29.1 \mathrm{GW}_{\text {th }}$ corresponding to 41.5 million square meters of solar collectors was installed worldwide. The overall new installations grew by $34.9 \%$ compared to 2007 . This represents a significant increase in the growth rate compared to 2006 / 2007 were the market grew only $18.8 \%$. The main reasons for this growth were the high growth rates of glazed water collectors in China $(+34.8 \%)$, Europe $(+62.5 \%)$ and in the United States $(+41.8 \%)$.

The share of glazed water collectors (flat-plate and evacuated tube) accounted for $27.5 \mathrm{GW}_{\text {th }}$ or $94.6 \%$ of the overall installations.

The global market for evacuated tube and flat plate collectors shows a steady rate of high growth, $35.4 \%$ and $42.7 \%$ respectively compared to the year 2007. Also, there was a significant increase in the market for unglazed air collectors $(+183.2 \%)$. The main reason for this was the installation of $23.9 \mathrm{MW}_{\text {th }}$ of new installations in Canada.

The most dynamic markets for water collectors (unglazed, glazed flat-plate and evacuated tube collectors) in 2008 were in some European countries. Compared to the capacity installed in 2007, Belgium increased its capacity in 2008 by $79 \%$, Cyprus by $158 \%$, Germany by $116 \%$, Ireland by $122 \%$, Macedonia by $105 \%$, Poland by $90 \%$ and Slovenia by $115 \%$.

Besides these European countries, the markets in Canada (128.5\%), Jordan (344\%), South Africa (71.8\%) and Tunisia $(100 \%)$ have recorded large growth rates.

New installations in China, the world's largest market, increased again significantly in 2008 by $34.8 \%$ compared to the year 2007. After a market decline in Japan in 2007 the growth rate was once again positive in $2008(+21.9 \%)$.

Market decreases compared to 2007 were reported for Israel (-7\%), the Slovak Republic (-47\%) and Taiwan ($12.7 \%)$.

The main markets for unglazed water collectors are still found in the United States ( $\left.0.8 \mathrm{GW}_{\text {th }}\right)$, Australia $\left(0.4 \mathrm{GW}_{\text {th }}\right)$ and Brazil $\left(0.08 \mathrm{GW}_{\mathrm{th}}\right)$. Notable markets are also in Austria, Canada, Mexico, The Netherlands, South Africa, Spain, Sweden and Switzerland with values between 0.07 and $0.01 \mathrm{GW}_{\text {th }}$ of new installed unglazed water collectors in 2008.

\section{Market development 2000 - 2008}

The annually installed glazed water collector area worldwide 2008 was more than 4 times higher than in the year 2000 and was doubled between 2004 and 2008. The worldwide average annual growth rate between 2000 and 2008 was $20.1 \%$ 
The worldwide market of unglazed collectors for swimming pool heating recorded an increase in 2000 and remained steady between 2001 and 2003. After a slight increase from 2004 to 2006 the installed capacity rate decreased again in 2007, mainly caused by the major market decline in the United States and Canada. In 2008, a growth was recorded in Central and South America, as well as in South Africa. All other markets remained quite stable.

\section{Contribution of solar collectors to the supply of energy}

The annual collector yield of all solar thermal systems in operation by the end of 2008 in the 53 recorded countries is $109,713 \mathrm{GWh}(394,968 \mathrm{TJ})$. This corresponds to an oil equivalent of 12.4 million tons and an annual avoidance of 39.4 million tons of $\mathrm{CO}_{2}$.

These values have been calculated from only the water-based systems. Air systems are excluded because the application database for air collectors is insufficient.

\section{Employment}

Based on data collected from detailed country reports, the jobs in the fields of production, installation and maintenance of solar thermal systems is estimated to be 260,000 worldwide.

\section{Preview 2009}

Based on the data available for the major markets in Europe, China and India at the date of publishing this report, the estimated total capacity in operation worldwide in 2009 is $189 \mathrm{GW}_{\mathrm{th}}$, corresponding to 270 million square meters of collector area.

Compared with other forms of renewable energy, solar heating's contribution in meeting global energy demand is, besides the traditional renewable energies like biomass and hydropower, second only to wind power, and has a much larger contribution than photovoltaics (Figure 2). This fact is still underestimated in energy policies.

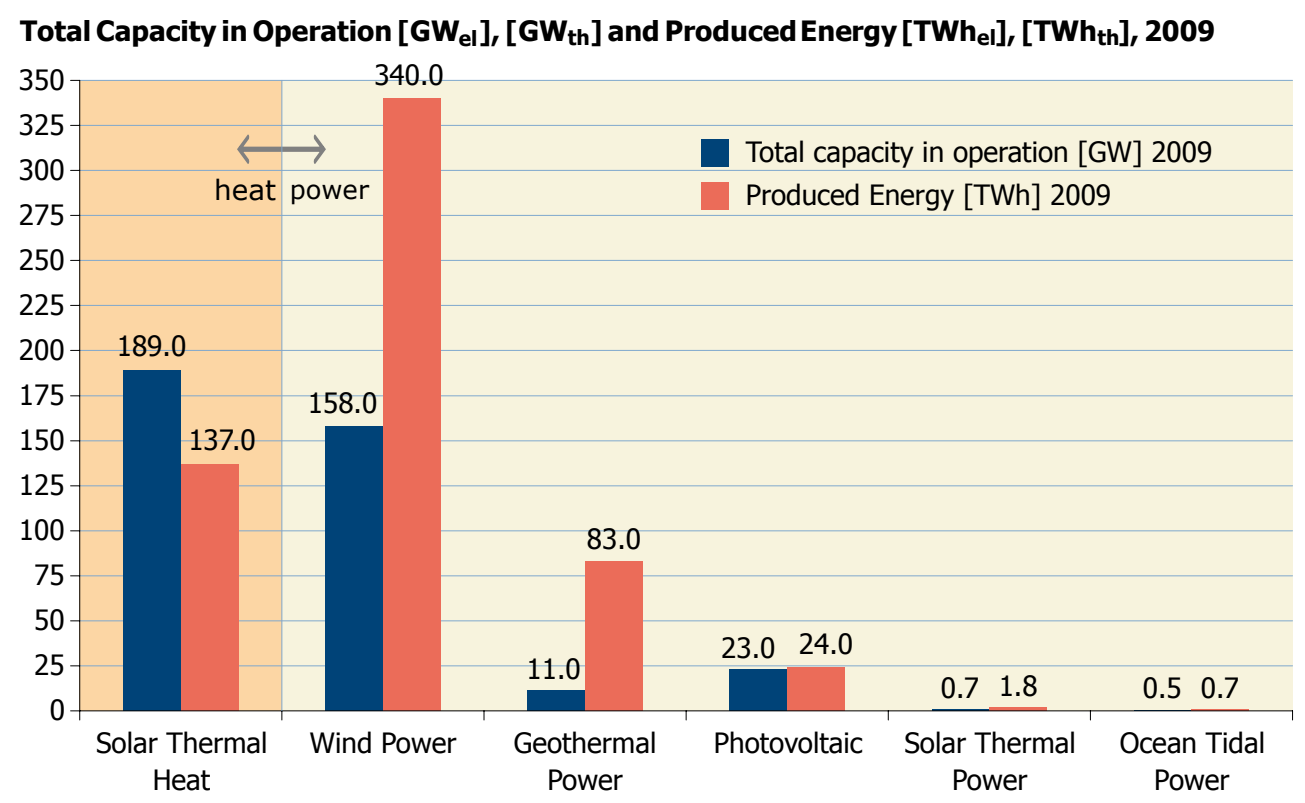

Figure 2: Total capacity in operation [GW $\mathrm{el}$, [GW th 2009 and annually energy generated [TWhel $],\left[T W h_{t h}\right]$. Sources: EPIA, GWEC, EWEA, EGEC, REN21 and IEA SHC 2009 


\section{Total capacity by the year 2008}

This report aims to give the actual collector area that is in operation and not the cumulated collector area that has ever been installed in a country. To determine the collector area (and respectively capacity) in operation, either official country reports on the lifetime base were used or, if such reports were not available, a 25-year lifetime for a system was calculated. The collector area in operation was then calculated using a linear equation.

\subsection{The main markets}

Since the beginning of the 1990s, the solar thermal market has undergone a favorable development. At the end of 2008 , a total of 217.0 million square meters of collector area, corresponding to an installed capacity $151.9 \mathrm{GW}_{\text {th }}$ was in operation in the 53 countries recorded in this report. These 53 countries represent 4.17 billion people, which is $61 \%$ of the world's population. The installed capacity in these countries represents approximately $85-90 \%$ of the solar thermal market worldwide.

The main markets (glazed and unglazed water collectors as well as glazed and unglazed air collectors) are in China (87.5 GW $\mathrm{GW}_{\text {th }}$ ), Europe (28.5 GW $\mathrm{GW}_{\text {th }}$ ) and the United States and Canada (15.1 GW $\mathrm{GW}_{\text {th }}$ ), which together account for $86.3 \%$ of the market share. The remaining share of the market is divided between Japan ( $4.42 \mathrm{GW}_{\mathrm{th}}$ ), Australia and New Zealand (4.36 $\left.\mathrm{GW}_{\text {th }}\right)$, some Asian countries (4.02 GW represented by Israel and Jordan $\left(3.29 \mathrm{GW}_{\mathrm{th}}\right.$ ) and some African countries $\left(0.9 \mathrm{GW}_{\mathrm{th}}\right)$, namely Namibia, South Africa, Tunisia and Zimbabwe.

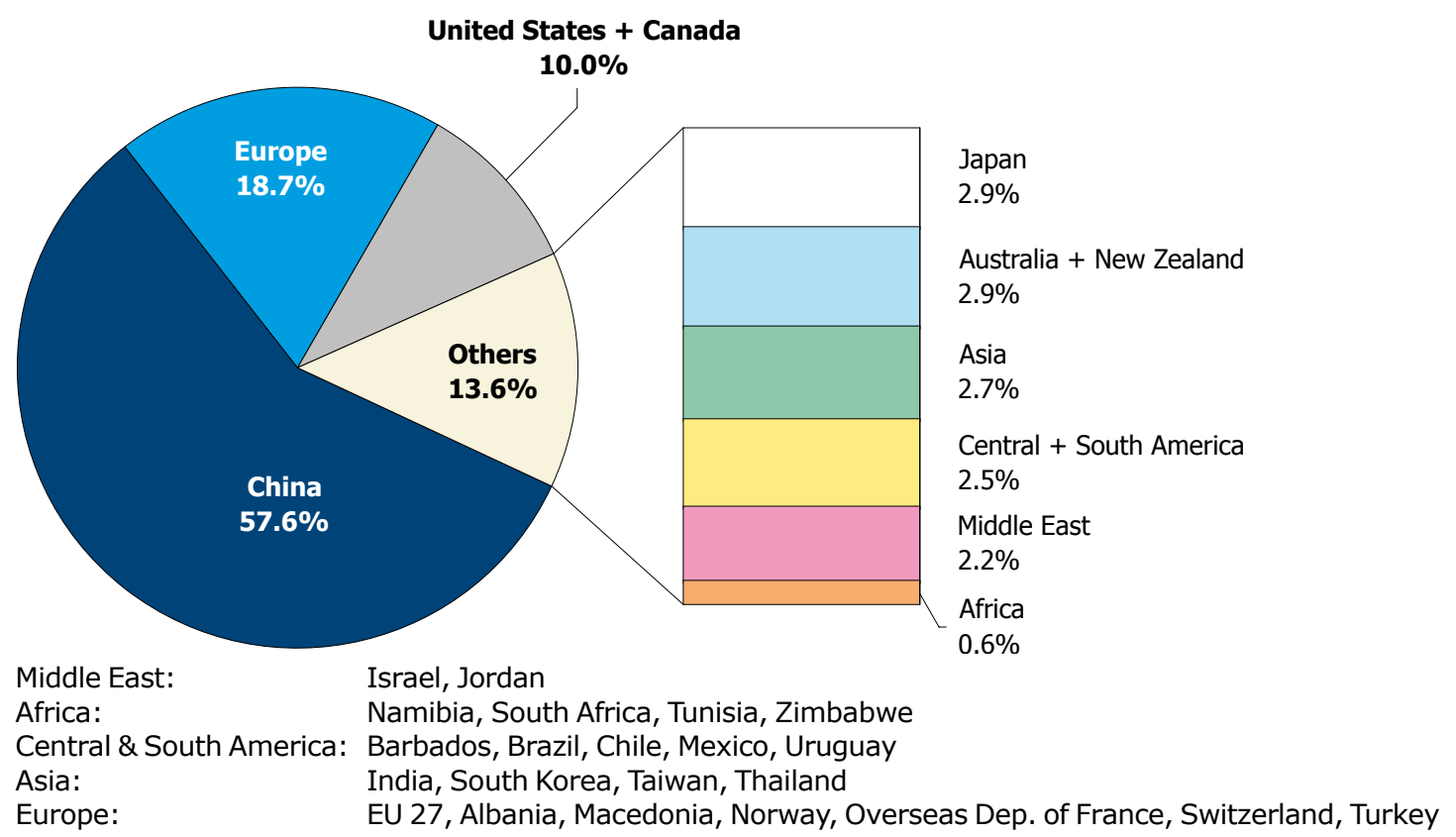

Figure 3: Share of the total collector installations (glazed and unglazed water and air collectors)

by economic regions at the end of 2008

As shown in Table 1 and Table 2, the total capacity is divided into $49.5 \mathrm{GW}_{\text {th }}$ glazed flat-plate collectors (70.7 million square meters) and $82.3 \mathrm{GW}_{\text {th }}$ evacuated tube collectors (117.6 million square meters), $18.8 \mathrm{GW}_{\text {th }}$ unglazed collectors (26.9 million square meters) and $1.2 \mathrm{GW}_{\text {th }}$ glazed and unglazed air collectors (1.7 million square meters). 


\begin{tabular}{|c|c|c|c|c|c|c|}
\hline \multirow{2}{*}{ ountry } & \multicolumn{3}{|c|}{ Water Collectors* } & \multicolumn{2}{|c|}{ Air Collectors* } & \multirow{2}{*}{ TOTAL $\left[\mathrm{MW}_{\mathrm{th}}\right]$} \\
\hline & unglazed & glazed & evacuated tube & unglazed & glazed & \\
\hline Albania & & 40.1 & 0.2 & & & 40.3 \\
\hline Australia & $2,870.0$ & $1,372.4$ & 26.2 & & & $4,268.6$ \\
\hline Austria & 436.9 & $2,305.2$ & 32.9 & & & $2,775.0$ \\
\hline Barbados & & 57.5 & & & & 57.5 \\
\hline Belgium & 32.8 & 145.0 & 14.4 & & & 192.2 \\
\hline Brazil & 562.0 & $2,443.3$ & & & & $3,005.2$ \\
\hline Bulgaria & & 21.2 & & & & 21.2 \\
\hline Canada & 507.7 & 63.8 & 3.9 & 110.3 & 0.9 & 686.6 \\
\hline Chile & 1.0 & 12.4 & & & & 13.4 \\
\hline China & & $7,170.3$ & $80,329.7$ & & & $87,500.0$ \\
\hline Cyprus & & 561.1 & 1.3 & & & 562.5 \\
\hline Czech Republic & 10.2 & 83.1 & 16.1 & & & 109.4 \\
\hline Denmark & 14.4 & 285.5 & 3.6 & 2.3 & 12.6 & 318.4 \\
\hline Estonia & & 1.3 & & & & 1.3 \\
\hline Finland & 8.2 & 16.3 & 0.8 & & & 25.4 \\
\hline France & 70.2 & $1,214.0$ & 22.2 & & & $1,306.4$ \\
\hline Germany & 504.0 & $6,507.7$ & 715.0 & & 23.5 & $7,750.2$ \\
\hline Greece & & $2,709.0$ & & & & $2,709.0$ \\
\hline Hungary & 1.9 & 33.5 & 3.4 & & & 38.8 \\
\hline India & & $1,756.3$ & 15.6 & & 11.4 & $1,783.3$ \\
\hline Ireland & & 39.9 & 13.3 & & & 53.2 \\
\hline Israel & 18.7 & $2,641.0$ & & 0.3 & & $2,660.0$ \\
\hline Italy & 17.7 & 840.0 & 174.7 & & & $1,032.4$ \\
\hline Japan & & $4,040.4$ & 71.1 & & 309.3 & $4,420.8$ \\
\hline Jordan & & 449.7 & 175.4 & & & 625.1 \\
\hline Korea & & 999.5 & & & & 999.5 \\
\hline Latvia & & 4.8 & & & & 4.8 \\
\hline Lithuania & & 2.9 & & & & 2.9 \\
\hline Luxembourg & & 14.6 & 0.5 & & & 15.1 \\
\hline Macedonia & & 15.4 & 0.5 & & & 15.9 \\
\hline Malta & & 23.8 & & & & 23.8 \\
\hline Mexico & 347.6 & 376.2 & & & & 723.8 \\
\hline Namibia & & 4.5 & 0.3 & & & 4.7 \\
\hline Netherlands & 252.6 & 240.0 & & & & 492.6 \\
\hline New Zealand & 4.6 & 82.9 & 6.8 & & & 94.2 \\
\hline Norway & 1.2 & 8.2 & 0.2 & & 0.8 & 10.5 \\
\hline Poland & 0.9 & 193.3 & 51.4 & 2.0 & 1.7 & 249.3 \\
\hline Portugal & 0.9 & 238.5 & 8.5 & & & 247.9 \\
\hline Romania & & 52.1 & & & & 52.1 \\
\hline Slovak Republic & & 67.4 & 7.7 & & & 75.1 \\
\hline Slovenia & & 83.1 & 2.8 & & & 85.9 \\
\hline South Africa & 489.8 & 180.8 & 12.2 & & & 682.8 \\
\hline Spain & 60.5 & $1,021.4$ & 67.2 & & & $1,149.1$ \\
\hline Sweden & 73.5 & 164.5 & 28.7 & & & 266.7 \\
\hline Switzerland** & 148.3 & 357.0 & 21.0 & 591.5 & & $1,117.7$ \\
\hline Taiwan & 1.3 & $1,154.2$ & 32.9 & & & $1,188.4$ \\
\hline Thailand & & 53.7 & & & & 53.7 \\
\hline Tunisia & & 195.9 & 4.4 & & & 200.3 \\
\hline IphaTurkey & & $7,445.8$ & & & & $7,445.8$ \\
\hline United Kingdom & & 218.5 & 40.8 & & & 259.3 \\
\hline United States & $12,409.0$ & $1,477.3$ & 430.2 & 0.1 & 113.5 & $14,430.0$ \\
\hline Uruguay & & 3.4 & & & & 3.4 \\
\hline Zimbabwe & & 12.1 & 0.02 & & & 12.1 \\
\hline TOTAL & $18,845.8$ & $49,501.8$ & $82,335.9$ & 706.4 & 473.8 & $151,863.7$ \\
\hline
\end{tabular}

* If no data is given: no reliable database for this collector type is available

** Unglazed air collectors in Switzerland: this is a very simple site-built system for hay drying

Table 1: Total capacity in operation at the end of 2008 [ $\left.\mathrm{MW}_{\mathrm{th}}\right]$ 


\begin{tabular}{|c|c|c|c|c|c|c|}
\hline \multirow{2}{*}{ Country } & \multicolumn{3}{|c|}{ Water Collectors* } & \multicolumn{2}{|c|}{ Air Collectors* } & \multirow{2}{*}{ TOTAL $\left[\mathrm{m}^{2}\right]$} \\
\hline & unglazed & glazed & evacuated tube & unglazed & glazed & \\
\hline Albania & & 57,283 & 336 & & & 57,619 \\
\hline Australia & $4,100,000$ & $1,960,550$ & 37,450 & & & $6,098,000$ \\
\hline Austria & 624,110 & $3,293,175$ & 47,069 & & & $3,964,354$ \\
\hline Barbados & & 82,104 & & & & 82,104 \\
\hline Belgium & 46,875 & 207,120 & 20,513 & & & 274,508 \\
\hline Brazil & 802,830 & $3,490,377$ & & & & $4,293,206$ \\
\hline Bulgaria & & 30,336 & & & & 30,336 \\
\hline Canada & 725,277 & 91,131 & 5,597 & 157,533 & 1,327 & 980,865 \\
\hline Chile & 1,470 & 17,730 & & & & 19,200 \\
\hline China & & $10,243,297$ & $114,756,703$ & & & $125,000,000$ \\
\hline Cyprus & & 801,637 & 1,883 & & & 803,520 \\
\hline Czech Republic & 14,621 & 118,646 & 23,030 & & & 156,298 \\
\hline Denmark & 20,515 & 407,866 & 5,184 & 3,264 & 18,000 & 454,829 \\
\hline Estonia & & 1,891 & & & & 1,891 \\
\hline Finland & 11,779 & 23,318 & 1,142 & & & 36,240 \\
\hline France & 100,320 & $1,734,240$ & 31,680 & & & $1,866,240$ \\
\hline Germany & 720,000 & $9,296,731$ & $1,021,423$ & & 33,600 & $11,071,754$ \\
\hline Greece & & $3,870,000$ & & & & $3,870,000$ \\
\hline Hungary & 2,688 & 47,846 & 4,858 & & & 55,392 \\
\hline India & & $2,508,948$ & 22,247 & & 16,320 & $2,547,515$ \\
\hline Ireland & & 57,009 & 19,001 & & & 76,010 \\
\hline Israel & 26,700 & $3,772,878$ & & 422 & & $3,800,000$ \\
\hline Italy & 25,219 & $1,200,000$ & 249,600 & & & $1,474,819$ \\
\hline Japan & & $5,772,026$ & 101,618 & & 441,856 & $6,315,500$ \\
\hline Jordan & & 642,477 & 250,588 & & & 893,065 \\
\hline Korea & & $1,427,834$ & & & & $1,427,834$ \\
\hline Latvia & & 6,864 & & & & 6,864 \\
\hline Lithuania & & 4,118 & & & & 4,118 \\
\hline Luxembourg & & 20,832 & 768 & & & 21,600 \\
\hline Macedonia & & 22,018 & 724 & & & 22,742 \\
\hline Malta & & 33,946 & & & & 33,946 \\
\hline Mexico & 496,591 & 537,430 & & & & $1,034,021$ \\
\hline Namibia & & 6,365 & 377 & & & 6,742 \\
\hline Netherlands & 360,815 & 342,926 & & & & 703,741 \\
\hline New Zealand & 6,544 & 118,361 & 9,644 & & & 134,550 \\
\hline Norway & 1,709 & 11,760 & 346 & & 1,152 & 14,966 \\
\hline Poland & 1,248 & 276,186 & 73,474 & 2,880 & 2,400 & 356,188 \\
\hline Portugal & 1,340 & 340,700 & 12,131 & & & 354,172 \\
\hline Romania & & 74,496 & & & & 74,496 \\
\hline Slovak Republic & & 96,292 & 10,955 & & & 107,246 \\
\hline Slovenia & & 118,656 & 4,042 & & & 122,698 \\
\hline South Africa & 699,678 & 258,314 & 17,368 & & & 975,360 \\
\hline Spain & 86,400 & $1,459,200$ & 96,000 & & & $1,641,600$ \\
\hline Sweden & 105,000 & 235,000 & 41,000 & & & 381,000 \\
\hline Switzerland** & 211,800 & 509,980 & 29,930 & 845,000 & & $1,596,710$ \\
\hline Taiwan & 1,860 & $1,648,836$ & 46,991 & & & $1,697,686$ \\
\hline Thailand & & 76,742 & & & & 76,742 \\
\hline Tunisia & & 279,862 & 6,218 & & & 286,080 \\
\hline Turkey & & $10,636,800$ & & & & $10,636,800$ \\
\hline United Kingdom & & 312,163 & 58,320 & & & 370,483 \\
\hline United States & $17,727,143$ & $2,110,364$ & 614,546 & 93 & 162,145 & $20,614,290$ \\
\hline Uruguay & & 4,861 & & & & 4,861 \\
\hline Zimbabwe & & 17,292 & 24 & & & 17,316 \\
\hline TOTAL & $26,922,531$ & $70,716,816$ & $117,622,779$ & $1,009,192$ & 676,799 & $216,948,117$ \\
\hline
\end{tabular}

* If no data is given: no reliable database for this collector type is available

** Unglazed air collectors in Switzerland: this is a very simple site-built system for hay drying

Table 2: Total installed collector area in operation at the end of 2008 [ $\mathrm{m}^{2}$ ] 
The 2008 distribution of the total installed capacity by the different types of solar collectors worldwide in operation is shown in Figure 4.

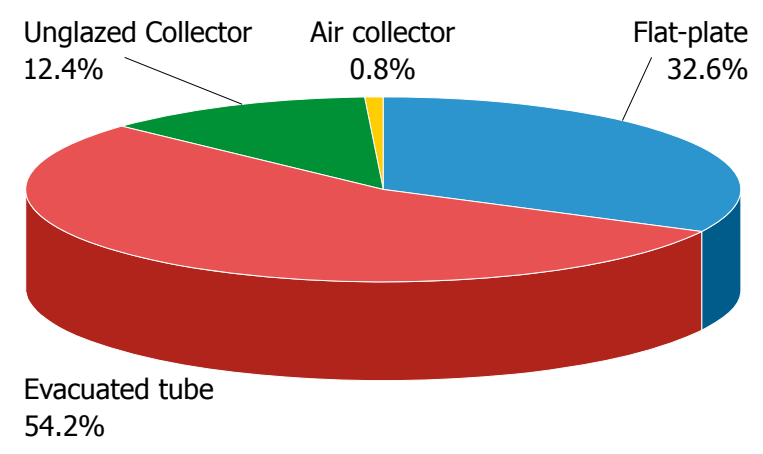

Figure 4: Distribution of the worldwide capacity in operation by collector type in 2008

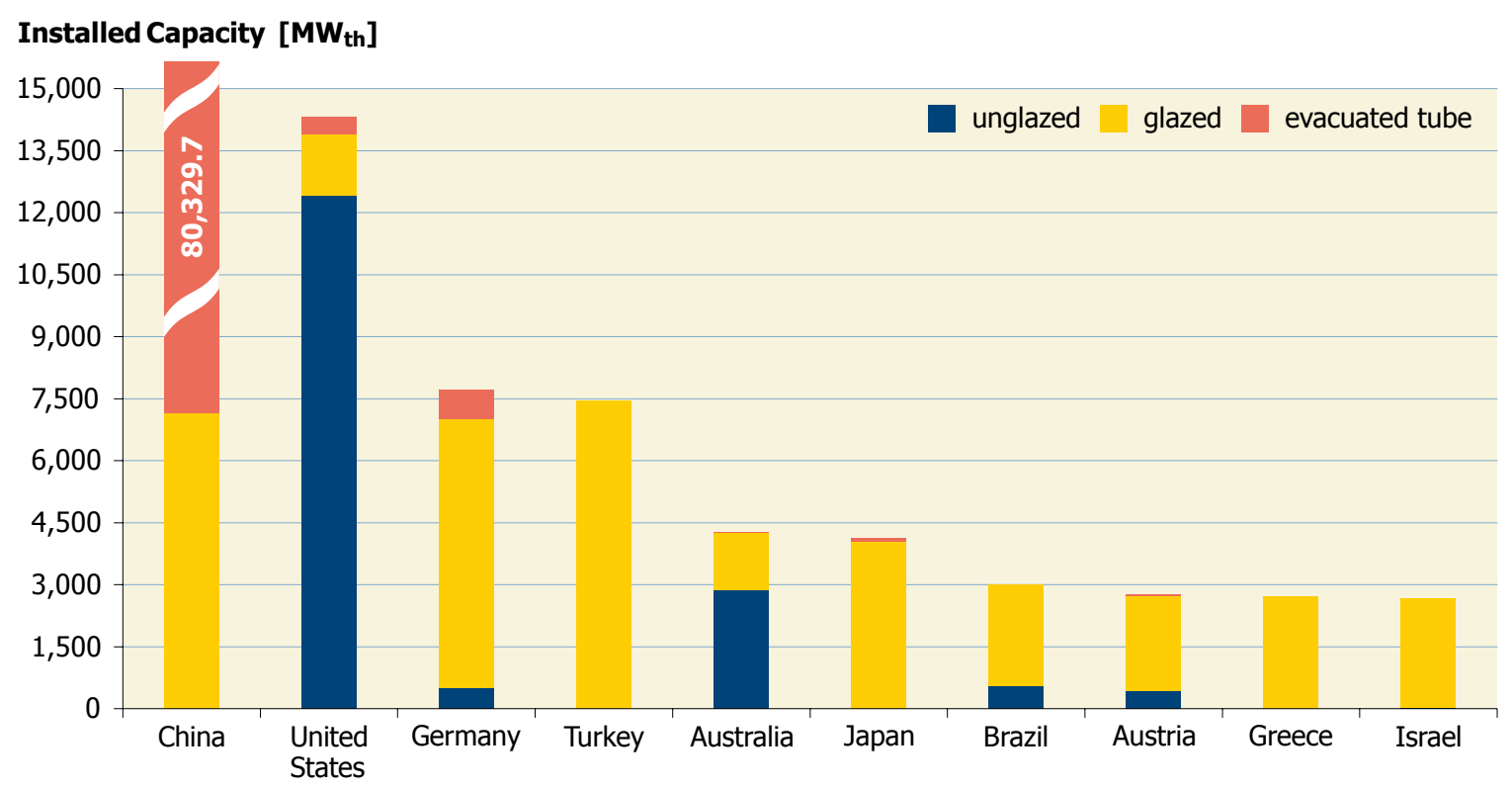

Figure 5: Total capacity of water collectors in operation in the 10 leading countries at the end of 2008

Figure 5 clearly shows how the different types of collectors are applied in the different countries. China, as world leader in total capacity, is focusing very much on evacuated tube collectors, whereas the United States are holding second position due to its high installation of unglazed water collectors. Only in Australia is the unglazed collector as important as in the United States. The rest of the "top 10 countries" are clearly focusing on the flat-plate collector.

In comparison to 2007, the top two positions remained the same. However Germany jumped ahead of Turkey in 2008 in terms of total installed capacity because of its significant market growth of about $116 \%$.

Israel lost its $7^{\text {th }}$ position in 2007 and dropped behind Brazil, Austria and Greece in 2008. This was due to the fact that a considerable number older installations were replaced and this was taken into account in this year's report. 


\subsection{Total capacity of glazed flat-plate and evacuated tube collectors at the end of 2008}

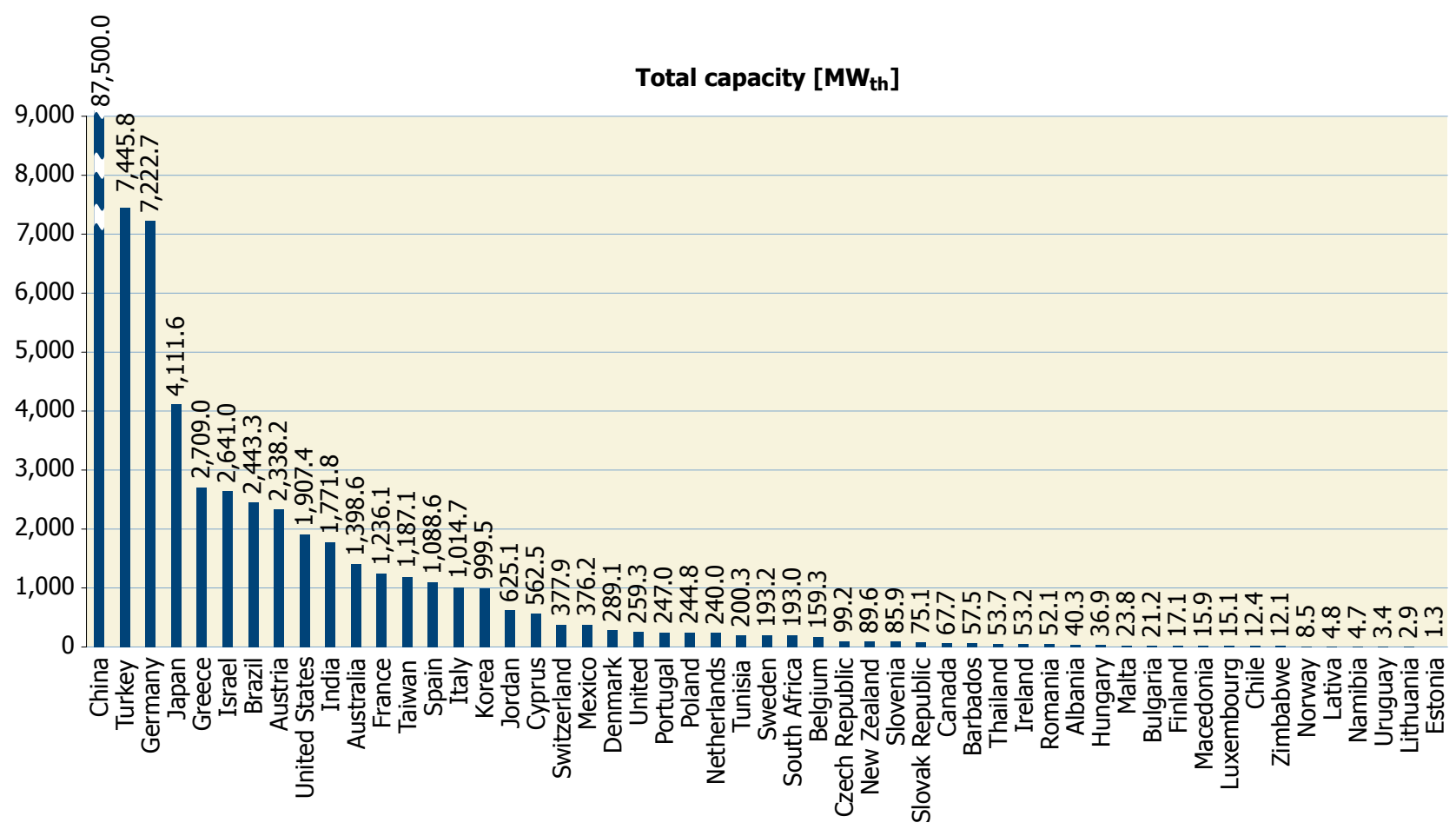

Figure 6: Total capacity of glazed flat-plate and evacuated tube collectors in operation at the end of 2008

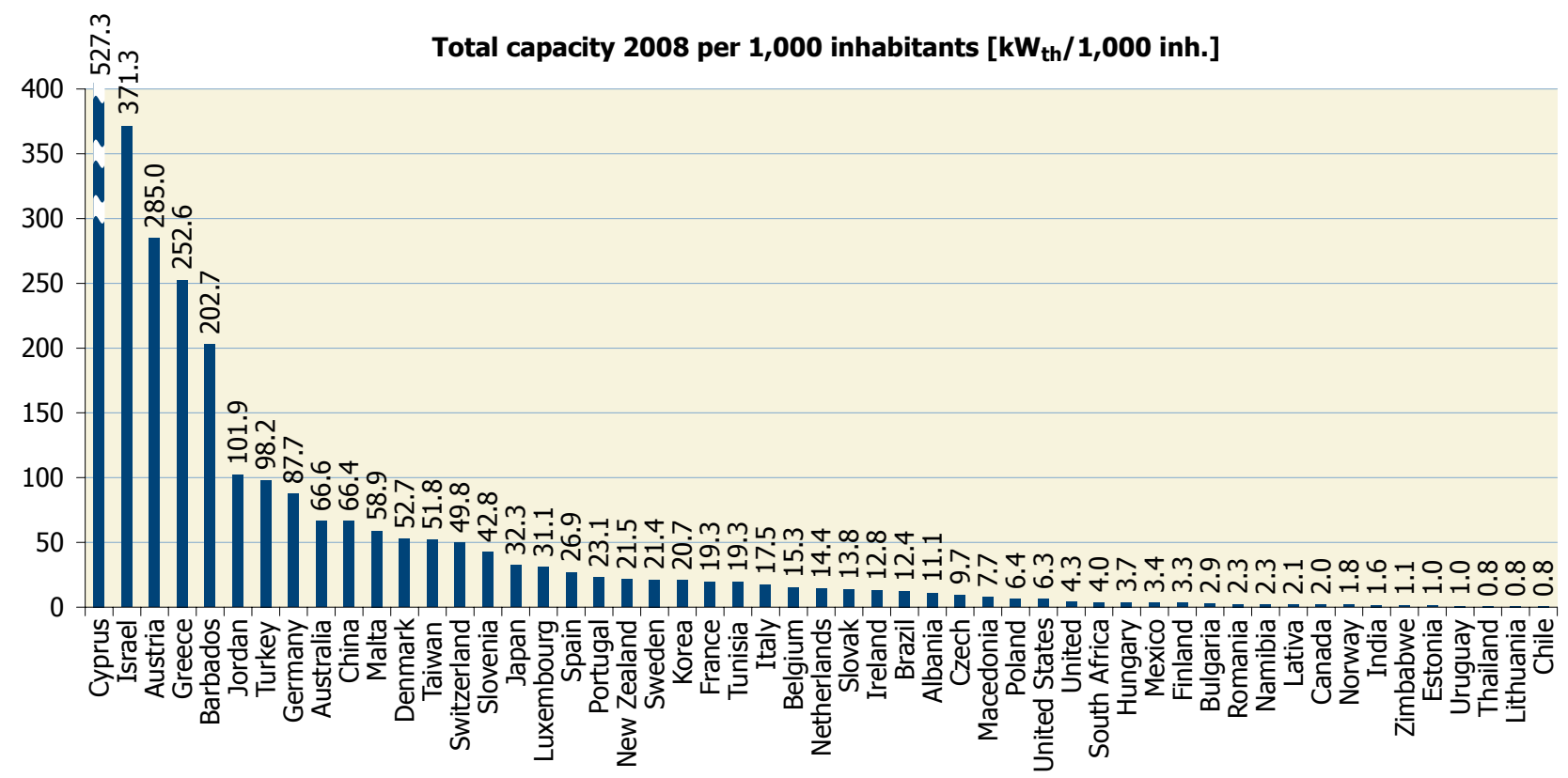

Figure 7: Total capacity of glazed flat-plate and evacuated tube collectors in operation at the end of 2008 in $\mathrm{kW}_{\text {th }}$ per 1,000 inhabitants 


\subsection{Total capacity of glazed flat-plate and evacuated tube collectors in operation at the end of $\mathbf{2 0 0 8}$ by economic region}

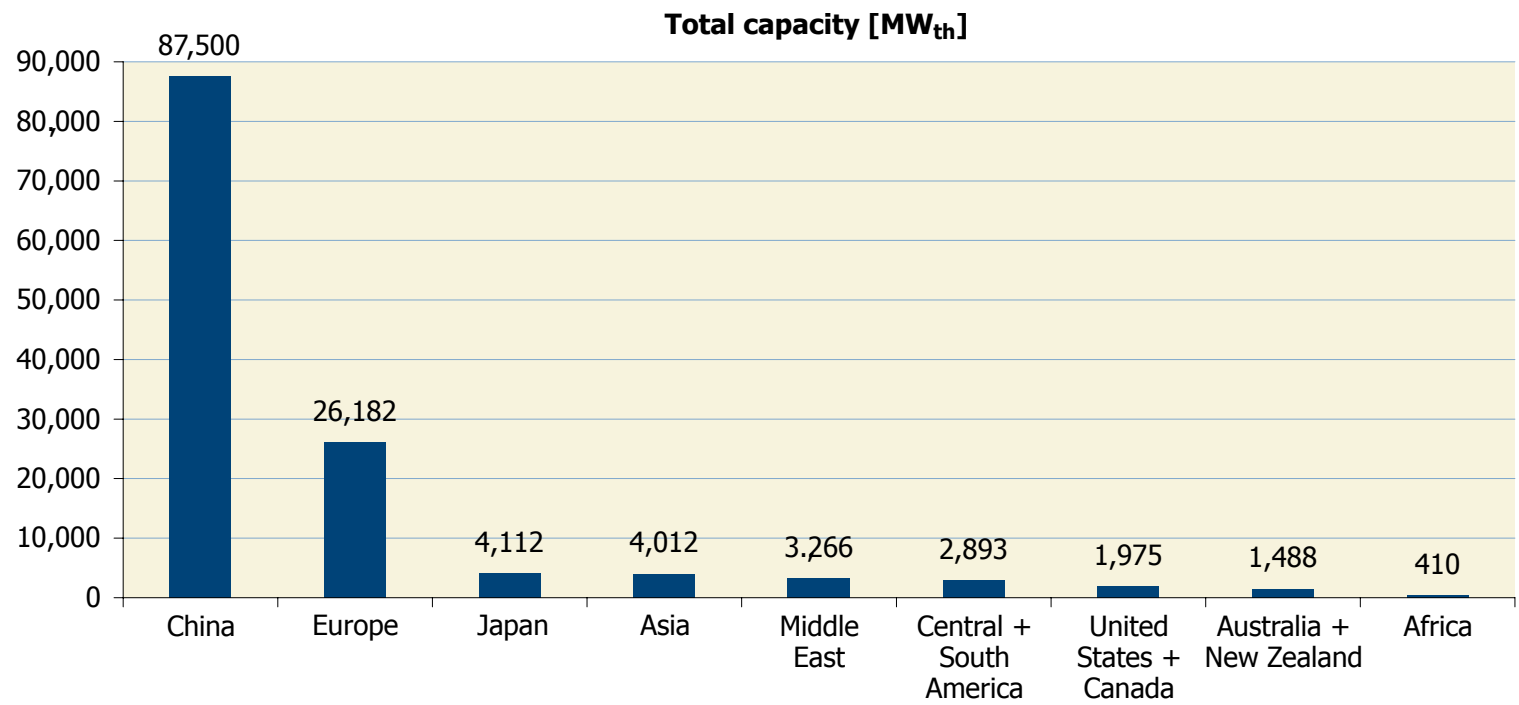

Middle East:

Israel, Jordan

Africa:

Namibia, South Africa, Tunisia, Zimbabwe

Central \& South America:

Asia:

Barbados, Brazil, Chile, Mexico, Uruguay

Europe:

India, South Korea, Taiwan, Thailand

EU 27, Albania, Macedonia, Norway, Overseas Dep. of France, Switzerland, Turkey

Figure 8: Total capacity of glazed flat-plate and evacuated tube collectors in operation by economic region at the end of 2008

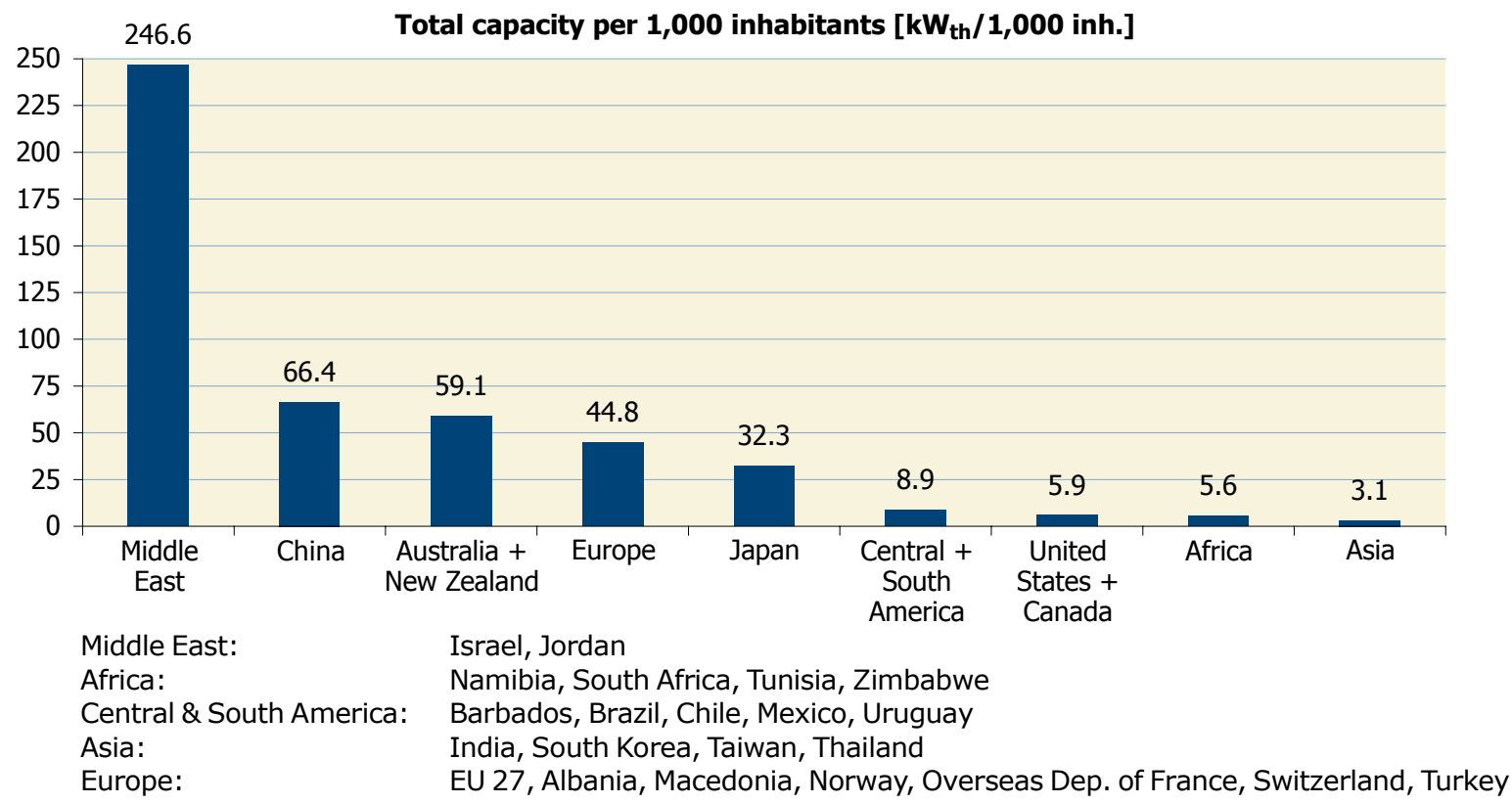

Figure 9: Total capacity of glazed flat-plate and evacuated tube collectors in operation by economic region at the end of 2008 in $\mathrm{kW}_{\text {th }}$ per 1,000 inhabitants 


\subsection{Total capacity of unglazed water collectors in operation at the end of 2008}

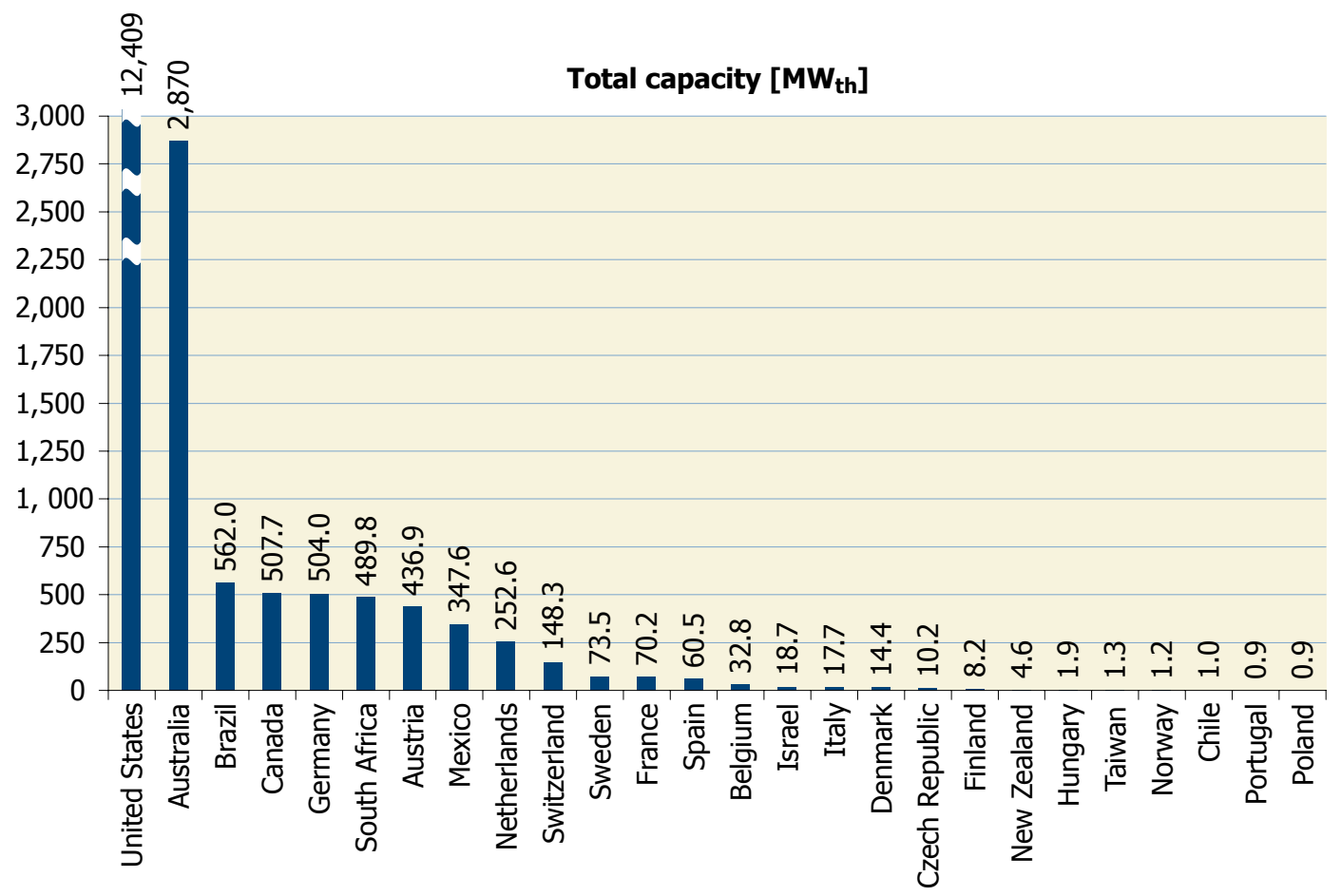

Figure 10: Total capacity of unglazed water collectors in operation at the end of 2008

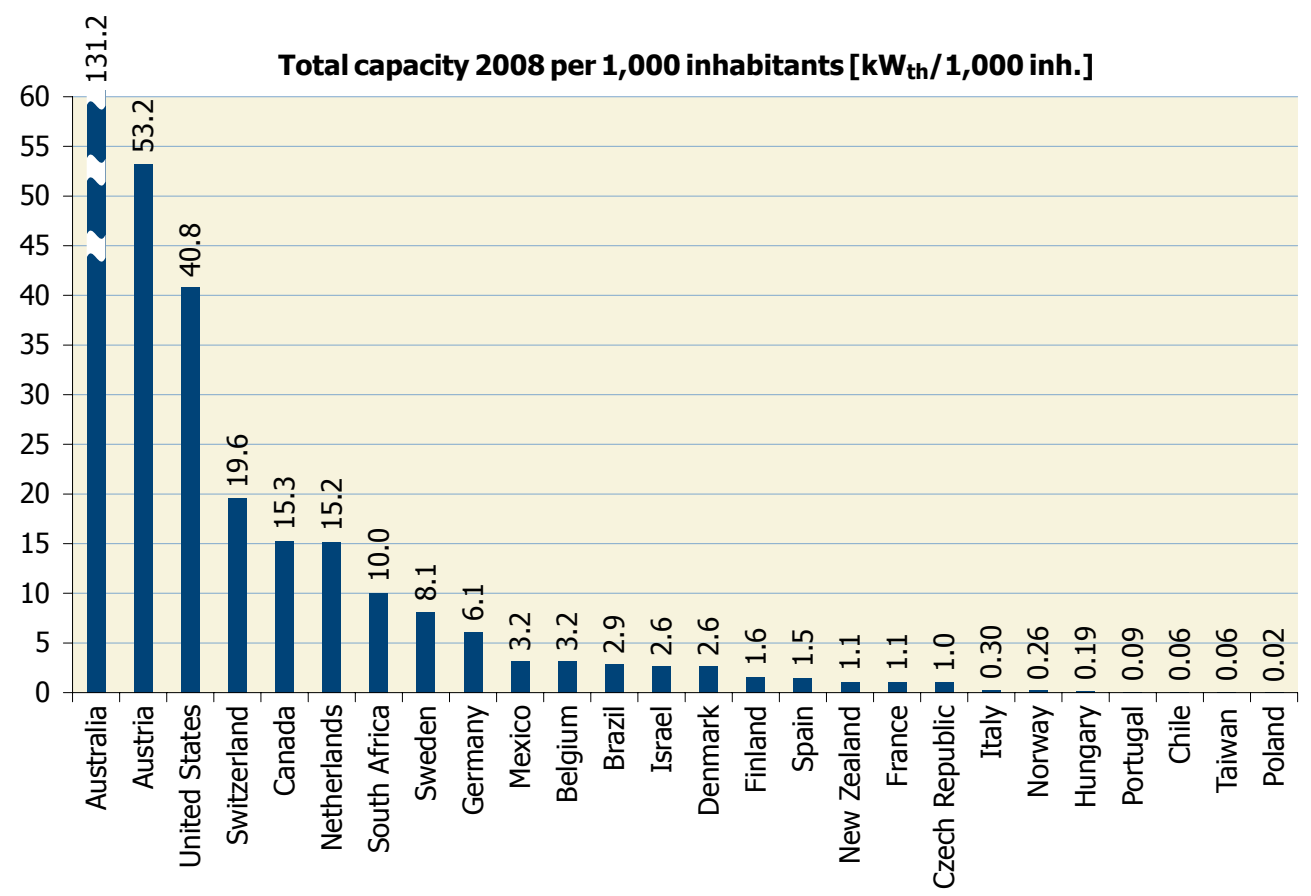

Figure 11: Total capacity of unglazed water collectors in operation at end of 2008 in kW th per 1,000 inhabitants 


\subsection{Total capacity of unglazed water collectors in operation by economic region at the end of $\mathbf{2 0 0 8}$}

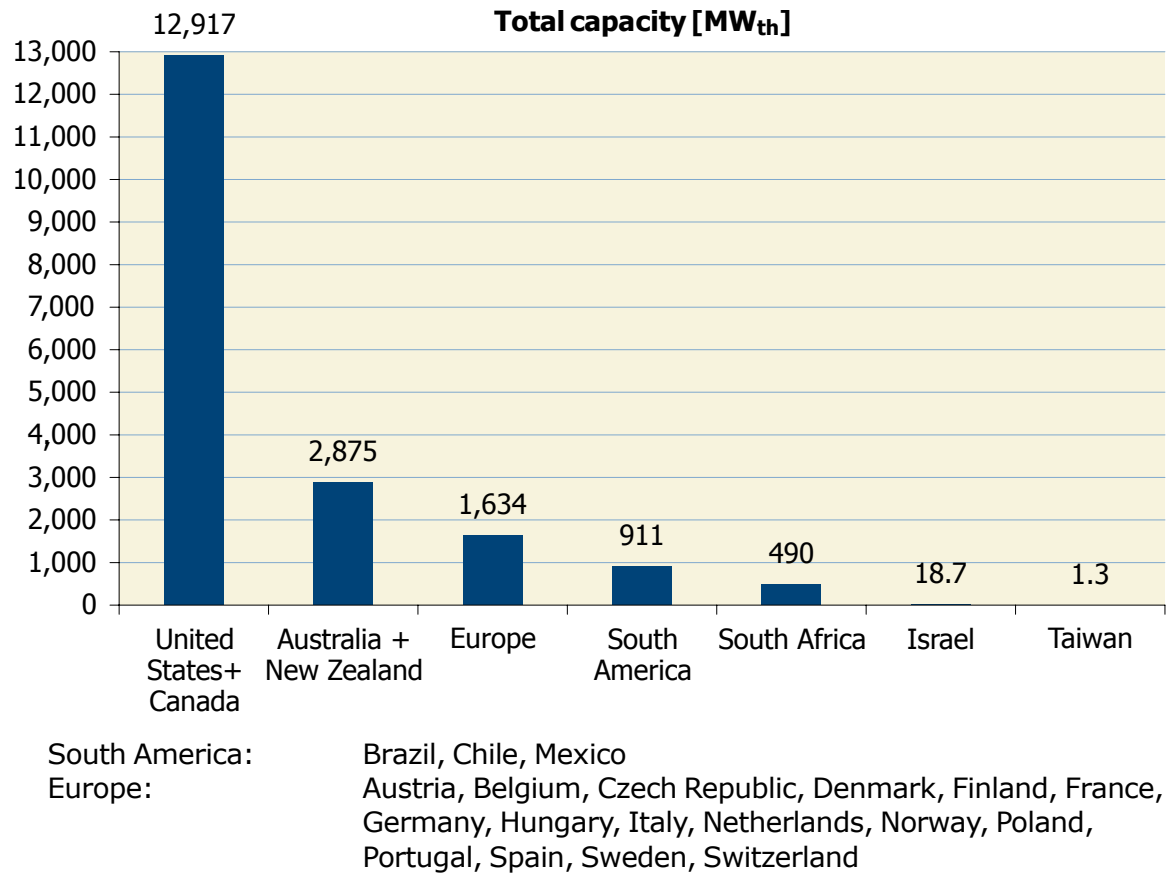

Figure 12: Total capacity of unglazed collectors in operation by economic region at the end of 2008

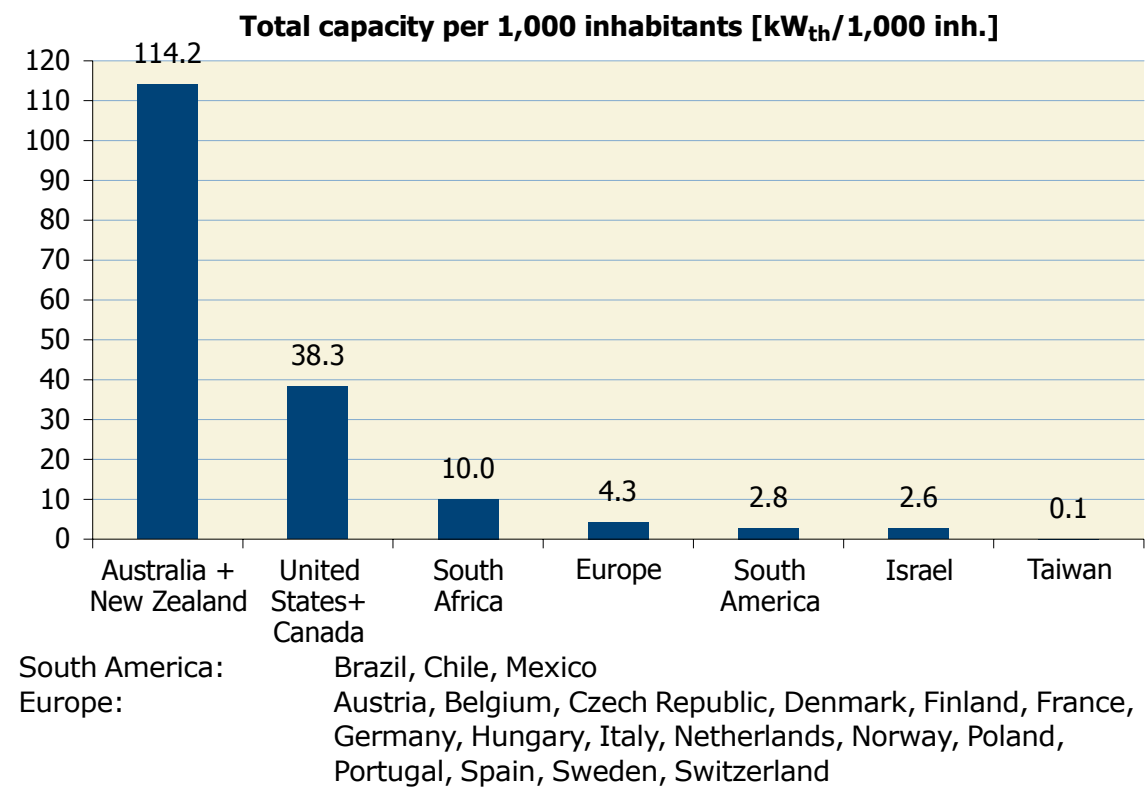

Figure 13: Total capacity of unglazed collectors in operation by economic region at the end of 2008 in $\mathrm{kW}_{\text {th }}$ per 1,000 inhabitants 


\section{Market development}

\subsection{Newly installed capacity in 2008}

In the year 2008, a capacity of $29.1 \mathrm{GW}_{\text {th }}$ corresponding to 41.5 million square meters of solar collectors were installed worldwide. Flat-plate and evacuated tube collectors accounted for $27.5 \mathrm{GW}_{\text {th }}$, representing $94.6 \%$ of the overall market.

The main markets for flat-plate and evacuated tube collectors worldwide were in China (21.7 GW $\left.\mathrm{G}_{\mathrm{th}}\right)$ and Europe $\left(4.0 \mathrm{GW}_{\text {th }}\right)$, which together account for $93.5 \%$. The rest of the market is shared between Central and South America represented by Barbados, Brazil, Chile, Mexico and Uruguay ( $\left.0.48 \mathrm{GW}_{\mathrm{th}}\right)$, the Asian countries of India, South Korea, Taiwan, Thailand $\left(0.47 \mathrm{GW}_{\text {th }}\right)$, the Middle East represented by Israel and Jordan $\left(0.23 \mathrm{GW}_{\text {th }}\right)$, Australia and New Zealand $\left(0.22 \mathrm{GW}_{\mathrm{th}}\right)$, the United States and Canada $\left(0.17 \mathrm{GW}_{\mathrm{th}}\right)$, Japan $\left(0.15 \mathrm{GW}_{\mathrm{th}}\right)$ and Africa represented by Namibia, South Africa, Tunisia and Zimbabwe (0.09 $\left.\mathrm{GW}_{\text {th }}\right)$.

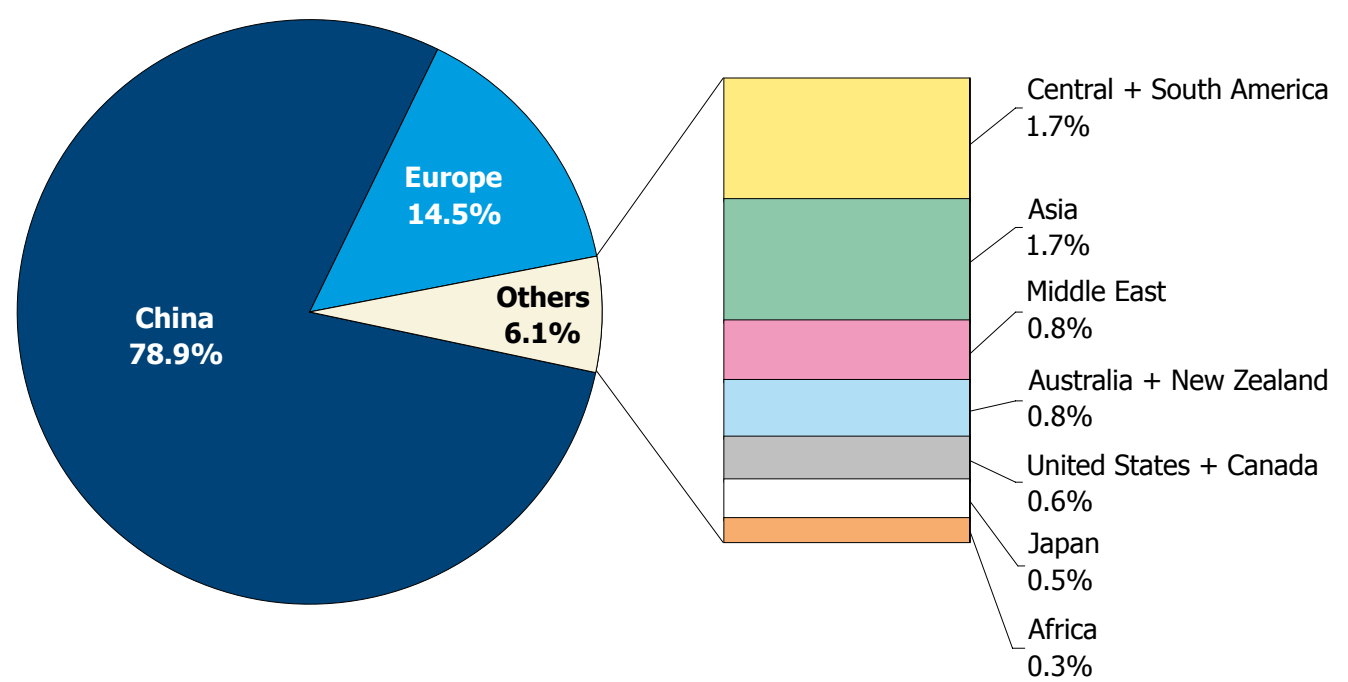

Figure 14: Share of the newly installed capacity of glazed water collectors by economic region in 2008

It is remarkable that after a stagnating market of flat plate collectors in the year 2007 (a market growth 3.3\% compared to 2006) that the market recovered 2008 with a growth rate of $42.7 \%$ compared to 2007 . The market of evacuated tube collectors experienced once again a high growth rate, $35.4 \%$ in 2008 , mainly due to the relentless growing market in China.

It should be mentioned that the Chinese market, as the absolute leader in vacuum tube collector production, is influencing other markets worldwide. Besides China and Jordan, in all the other recorded countries the flat plate collector remains the dominant collector type. Nevertheless, it is a remarkable trend that the evacuated tube collectors gained considerable market shares in Germany, Italy, Poland, the United States, the United Kingdom and Spain (Figure 15). In South Africa and Sweden evacuated tube collectors reached nearly similar market shares as the flat plate collector. 


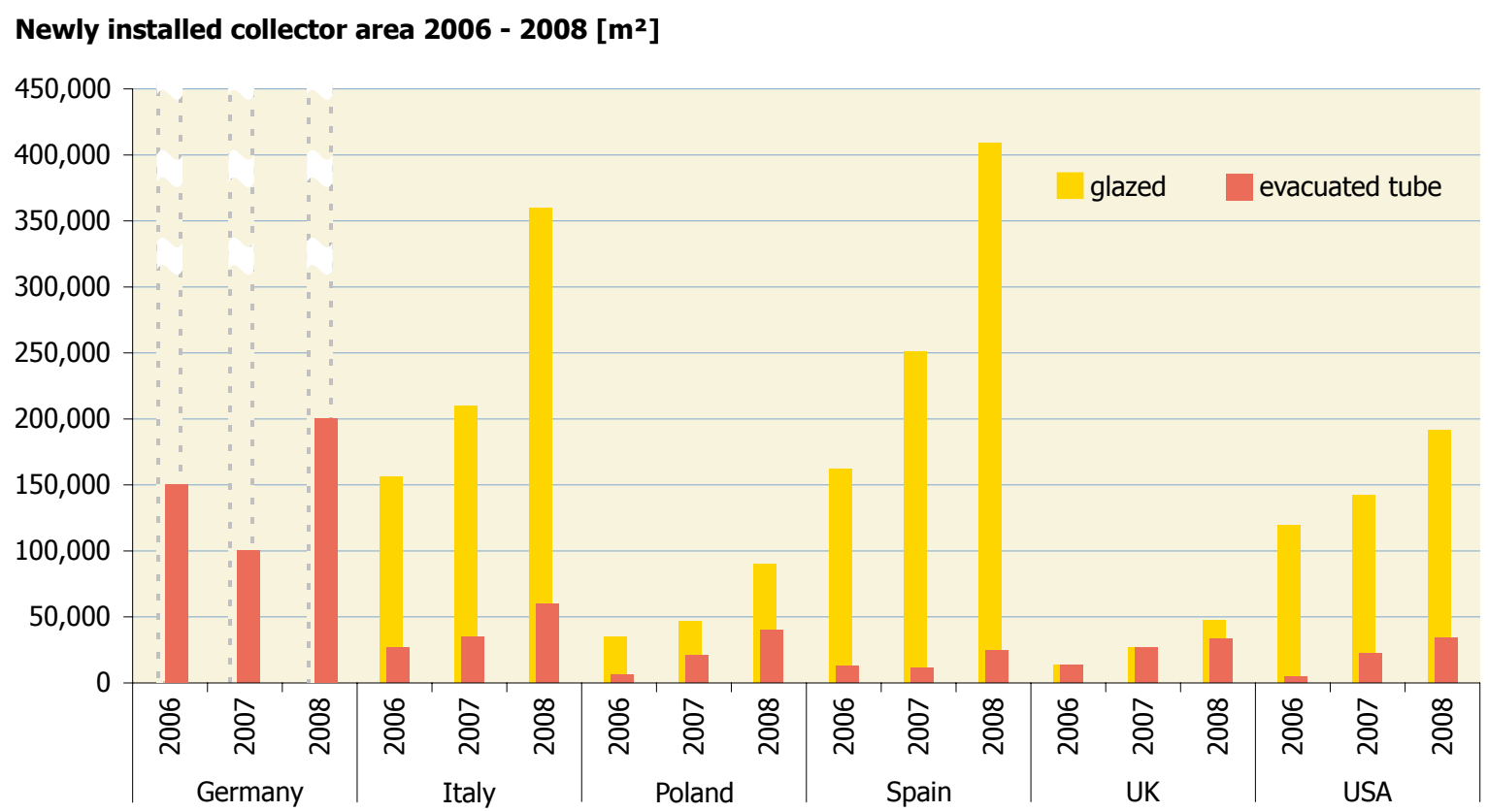

Figure 15: Annual flat plate and evacuated tube collector installations 2006-2008

The main markets for unglazed water collectors are found in the United States $\left(0.8 \mathrm{GW}_{\text {th }}\right)$ and Australia $\left(0.4 \mathrm{GW}_{\text {th }}\right)$ Notable markets also can be found in Brazil $\left(0.08 \mathrm{GW}_{\text {th }}\right)$ as well as in Austria, Canada, Mexico, South Africa, Spain, Sweden and Switzerland with values between 0.07 and $0.01 \mathrm{GW}_{\text {th }}$ of new installed unglazed water collectors in 2008.

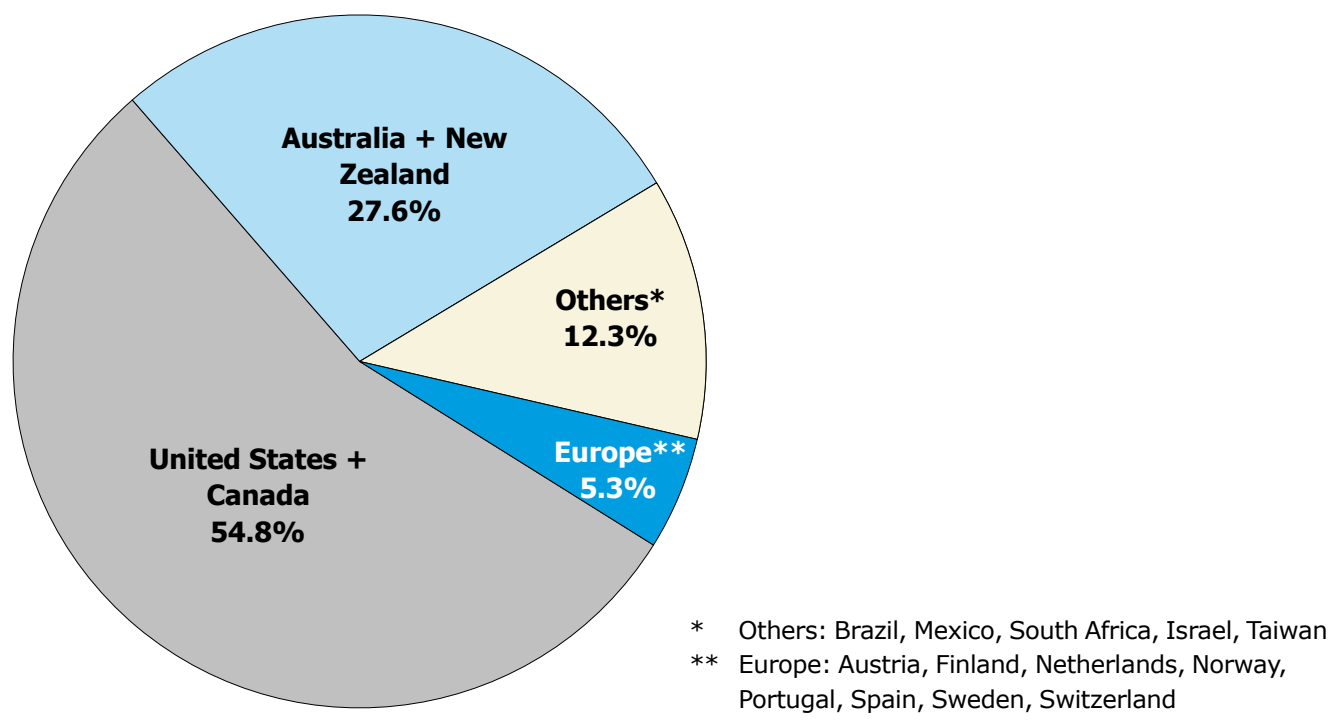

Figure 16: Share of the newly installed capacity of unglazed water collectors by economic region in 2008

After a decrease of unglazed water collector installations in 2007 (- 5.5\%), the market grew 5.4\% in 2008 .

The following tables show the annually installed capacity (Table 3) and the annually installed collector area (Table 4) in the recorded countries in 2008.

In the Appendix the tables containing data of the newly installed collector area for the years 2006 and 2007 (Table 15 and Table 16) can be found as well as the total installed collector area in 2007 (Table 17). 


\begin{tabular}{|c|c|c|c|c|c|c|}
\hline \multirow{2}{*}{ Country } & \multicolumn{3}{|c|}{ Water Collectors* } & \multicolumn{2}{|c|}{ Air Collectors* } & \multirow{2}{*}{ TOTAL $\left[M W_{\text {th }} / a\right]$} \\
\hline & unglazed & glazed & evacuated tube & unglazed & glazed & \\
\hline Albania & & 6.8 & 0.1 & & & 6.9 \\
\hline Australia & 420.0 & 193.9 & 9.8 & & & 623.7 \\
\hline Austria & 10.7 & 240.5 & 2.9 & & & 254.0 \\
\hline Barbados & & 1.9 & & & & 1.9 \\
\hline Belgium & & 57.4 & 6.3 & & & 63.7 \\
\hline Brazil & 81.3 & 388.5 & & & & 469.8 \\
\hline Bulgaria & & 2.8 & & & & 2.8 \\
\hline Canada & 62.7 & 9.2 & 0.8 & 23.9 & 0.8 & 97.4 \\
\hline Chile & & 6.3 & & & & 6.3 \\
\hline China & & $1,085.0$ & $20,615.0$ & & & $21,700.0$ \\
\hline Cyprus & & 28.2 & 0.7 & & & 28.9 \\
\hline Czech Republic & & 18.6 & 6.0 & & & 24.5 \\
\hline Denmark & & 21.7 & 1.4 & & & 23.1 \\
\hline Estonia & & 0.4 & & & & 0.4 \\
\hline Finland & 0.2 & 2.7 & 0.5 & & & 3.4 \\
\hline France & & 273.0 & & & & 273.0 \\
\hline Germany & & $1,330.0$ & 140.0 & & 4.8 & $1,474.8$ \\
\hline Greece & & 208.6 & & & & 208.6 \\
\hline Hungary & & 6.0 & 1.8 & & & 7.7 \\
\hline India & & 324.4 & 16.2 & & & 340.7 \\
\hline Ireland & & 22.2 & 8.3 & & & 30.5 \\
\hline Israel & 1.8 & 194.6 & & & & 196.4 \\
\hline Italy & & 252.0 & 42.0 & & & 294.0 \\
\hline Japan & & 143.9 & 1.4 & & 9.4 & 154.7 \\
\hline Jordan & & 14.0 & 21.0 & & & 35.1 \\
\hline Korea & & 36.1 & & & & 36.1 \\
\hline Latvia & & 1.3 & & & & 1.3 \\
\hline Lithuania & & 0.6 & & & & 0.6 \\
\hline Luxembourg & & 2.0 & 0.6 & & & 2.5 \\
\hline Macedonia & & 2.7 & 0.4 & & & 3.1 \\
\hline Malta & & 4.2 & & & & 4.2 \\
\hline Mexico & 34.8 & 81.2 & & & & 115.9 \\
\hline Namibia & & 2.8 & 0.1 & & & 2.9 \\
\hline Netherlands & 19.8 & 16.4 & & & & 36.1 \\
\hline New Zealand & 0.4 & 14.3 & & & & 14.7 \\
\hline Norway & 0.1 & 0.7 & 0.1 & & & 1.0 \\
\hline Poland & & 62.9 & 27.9 & & & 90.7 \\
\hline Portugal & 0.6 & 55.2 & 5.0 & & & 60.8 \\
\hline Romania & & 5.6 & & & & 5.6 \\
\hline Slovak Republic & & 8.4 & 1.1 & & & 9.5 \\
\hline Slovenia & & 9.8 & 1.8 & & & 11.6 \\
\hline South Africa & 70.2 & 15.0 & 12.7 & & & 97.8 \\
\hline Spain & 22.4 & 286.3 & 17.5 & & & 326.2 \\
\hline Sweden & 20.1 & 10.2 & 8.6 & & & 38.8 \\
\hline Switzerland** & 6.6 & 72.8 & 6.2 & 4.9 & & 90.4 \\
\hline Taiwan & 0.2 & 74.0 & 8.2 & & & 82.4 \\
\hline Thailand & & 7.0 & & & & 7.0 \\
\hline Tunisia & & 52.5 & 3.5 & & & 56.0 \\
\hline Turkey & & 651.0 & & & & 651.0 \\
\hline United Kingdom & & 33.1 & 23.6 & & & 56.7 \\
\hline United States & 773.9 & 134.1 & 23.7 & & 1.8 & 933.5 \\
\hline Uruguay & & 2.9 & & & & 2.9 \\
\hline Zimbabwe & & 0.2 & 0.02 & & & 0.3 \\
\hline TOTAL & $1,525.5$ & $6,475.8$ & $21,014.9$ & 28.8 & 16.9 & $29,061.77$ \\
\hline
\end{tabular}

* If no data is given: no reliable database for this collector type is available

** Unglazed air collectors in Switzerland: this is a very simple site-built system for hay drying

Table 3: Newly installed capacity in 2008 [ $\left.\mathrm{MW}_{\mathrm{th}} / \mathrm{a}\right]$ 


\begin{tabular}{|c|c|c|c|c|c|c|}
\hline \multirow{2}{*}{ Country } & \multicolumn{3}{|c|}{ Water Collectors* } & \multicolumn{2}{|c|}{ Air Collectors* } & \multirow{2}{*}{ TOTAL $\left[\mathbf{m}^{2}\right]$} \\
\hline & unglazed & glazed & evacuated tube & unglazed & glazed & \\
\hline Albania & & 9,740 & 104 & & & 9,844 \\
\hline Australia & 600,000 & 277,000 & 14,000 & & & 891,000 \\
\hline Austria & 15,220 & 343,617 & 4,086 & & & 362,923 \\
\hline rBarbados & & 2,731 & & & & 2,731 \\
\hline Belgium & & 82,000 & 9,000 & & & 91,000 \\
\hline Brazil & 116,110 & 555,046 & & & & 671,156 \\
\hline Bulgaria & & 4,000 & & & & 4,000 \\
\hline Canada & 89,577 & 13,173 & 1,083 & 34,135 & 1,191 & 139,159 \\
\hline Chile & & 9,000 & & & & 9,000 \\
\hline China & & $1,550,000$ & $29,450,000$ & & & $31,000,000$ \\
\hline Cyprus & & 40,290 & 1,000 & & & 41,290 \\
\hline Czech Republic & & 26,500 & 8,500 & & & 35,000 \\
\hline Denmark & & 31,000 & 2,000 & & & 33,000 \\
\hline Estonia & & 500 & & & & 500 \\
\hline Finland & 270 & 3,905 & 650 & & & 4,825 \\
\hline France & & 390,000 & & & & 390,000 \\
\hline Germany & & $1,900,000$ & 200,000 & & 6,900 & $2,106,900$ \\
\hline Greece & & 298,000 & & & & 298,000 \\
\hline Hungary & & 8,500 & 2,500 & & & 11,000 \\
\hline India & & 463,487 & 23,174 & & & 486,662 \\
\hline OIreland & & 31,727 & 11,883 & & & 43,610 \\
\hline Israel & 2,500 & 278,000 & & & & 280,500 \\
\hline Italy & & 360,000 & 60,000 & & & 420,000 \\
\hline Japan & & 205,622 & 1,946 & & 13,386 & 220,954 \\
\hline Jordan & & 20,041 & 30,062 & & & 50,103 \\
\hline Korea & & 51,552 & & & & 51,552 \\
\hline Latvia & & 1,800 & & & & 1,800 \\
\hline Lithuania & & 840 & & & & 840 \\
\hline Luxembourg & & 2,800 & 800 & & & 3,600 \\
\hline Macedonia & & 3,866 & 554 & & & 4,420 \\
\hline Malta & & 6,000 & & & & 6,000 \\
\hline Mexico & 49,690 & 115,943 & & & & 165,633 \\
\hline Namibia & & 3,952 & 203 & & & 4,154 \\
\hline Netherlands & 28,216 & 23,414 & & & & 51,630 \\
\hline New Zealand & 600 & 20,379 & & & & 20,979 \\
\hline Norway & 180 & 1,030 & 210 & & & 1,420 \\
\hline Poland & & 89,820 & 39,812 & & & 129,632 \\
\hline Portugal & 802 & 78,858 & 7,160 & & & 86,820 \\
\hline Romania & & 8,000 & & & & 8,000 \\
\hline Slovak Republic & & 12,000 & 1,500 & & & 13,500 \\
\hline Slovenia & & 14,000 & 2,500 & & & 16,500 \\
\hline South Africa & 100,222 & 21,397 & 18,092 & & & 139,710 \\
\hline Spain & 32,000 & 409,000 & 25,000 & & & 466,000 \\
\hline Sweden & 28,648 & 14,530 & 12,283 & & & 55,461 \\
\hline Switzerland** & 9,374 & 104,040 & 8,793 & 7,000 & & 129,207 \\
\hline Taiwan & 330 & 105,683 & 11,751 & & & 117,764 \\
\hline Thailand & & 9,939 & & & & 9,939 \\
\hline Tunisia & & 75,000 & 5,000 & & & 80,000 \\
\hline Turkey & & 930,000 & & & & 930,000 \\
\hline United Kingdom & & 47,250 & 33,750 & & & 81,000 \\
\hline United States & $1,105,537$ & 191,564 & 33,816 & & 2,601 & $1,333,519$ \\
\hline Uruguay & & 4,213 & & & & 4,213 \\
\hline Zimbabwe & & 336 & 24 & & & 360 \\
\hline TOTAL & $2,179,275$ & $9,251,085$ & $30,021,236$ & 41,135 & 24,079 & $41,516,810$ \\
\hline
\end{tabular}

* If no data is given: no reliable database for this collector type is available

** Unglazed air collectors in Switzerland: this is a very simple site-built system for hay drying

Table 4: Newly Installed collector area in 2008 [m²/a] 


\subsection{Market development of glazed flat-plate and evacuated tube collectors by economic region}

Analyzing the market development of glazed water collectors, from 2000 to 2008, it can be seen that the market of flat-plate and evacuated tube collectors grew significantly during this time period (see Figure 17).

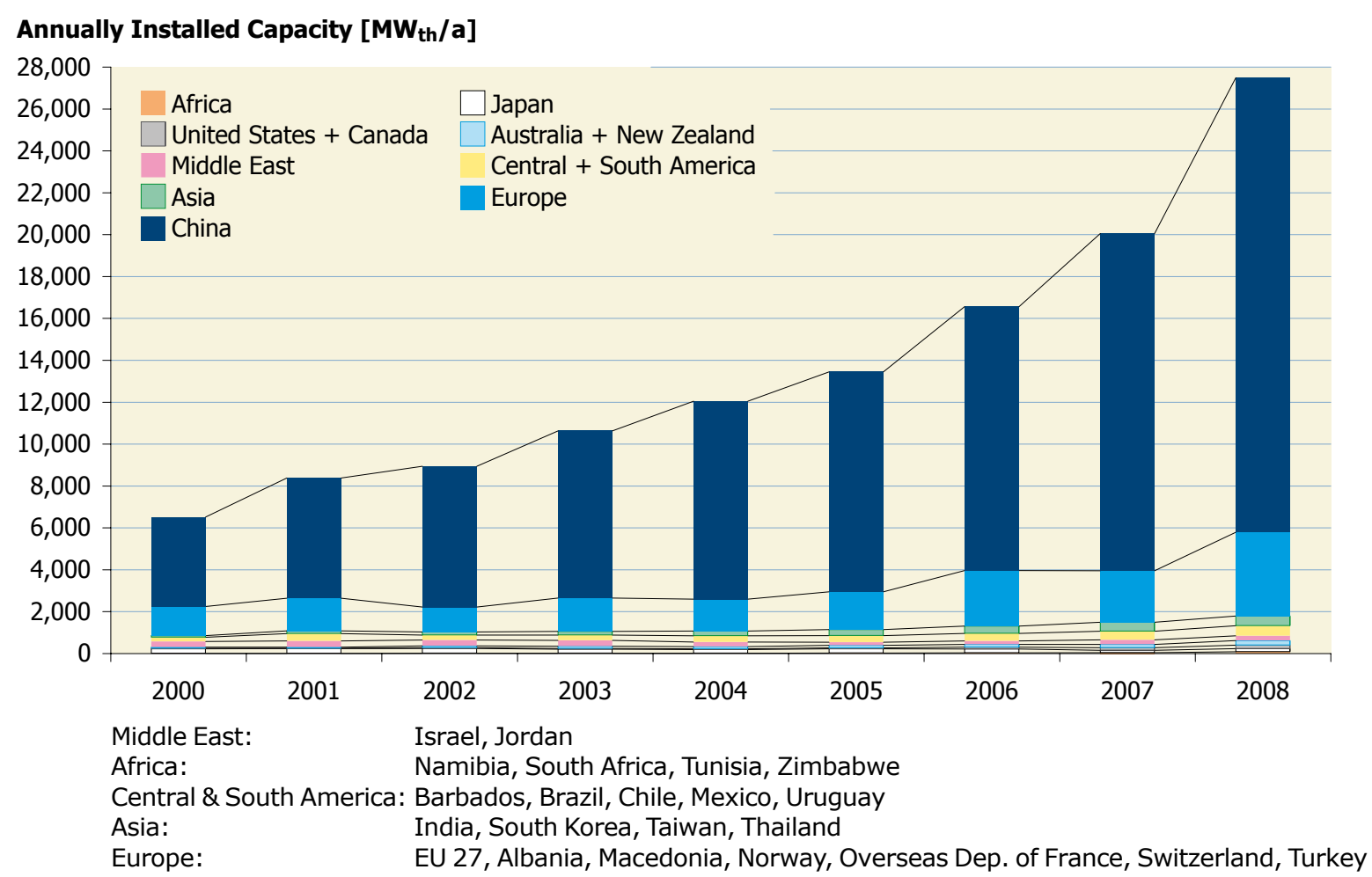

Figure 17: Annual installed capacity of flat-plate and evacuated tube collectors from 2000 to 2008

The annually installed glazed water collector area worldwide in 2008 was more than 4 times higher than in the year 2000 , and doubled between 2005 and 2008. The worldwide average annual growth rate between 2000 and 2008 was $20.1 \%$.

Compared to the year 2007, the worldwide market for glazed water collectors grew by $37.1 \%$. Especially high growth rates occurred in Europe $(+62.5 \%)$, the United States and Canada $(+41.8 \%)$, Australia and New Zealand $(+39.7 \%)$ and China $(+34.8 \%)$ are responsible for the above average growth in 2008.

After a market decline in Japan in 2007, the growth rate in 2008 was positive again in $2008(+21.9 \%)$. 
Installed capacity $\left[\mathrm{kW}_{\mathrm{th}} / \mathrm{a} / 1,000\right.$ inh.]

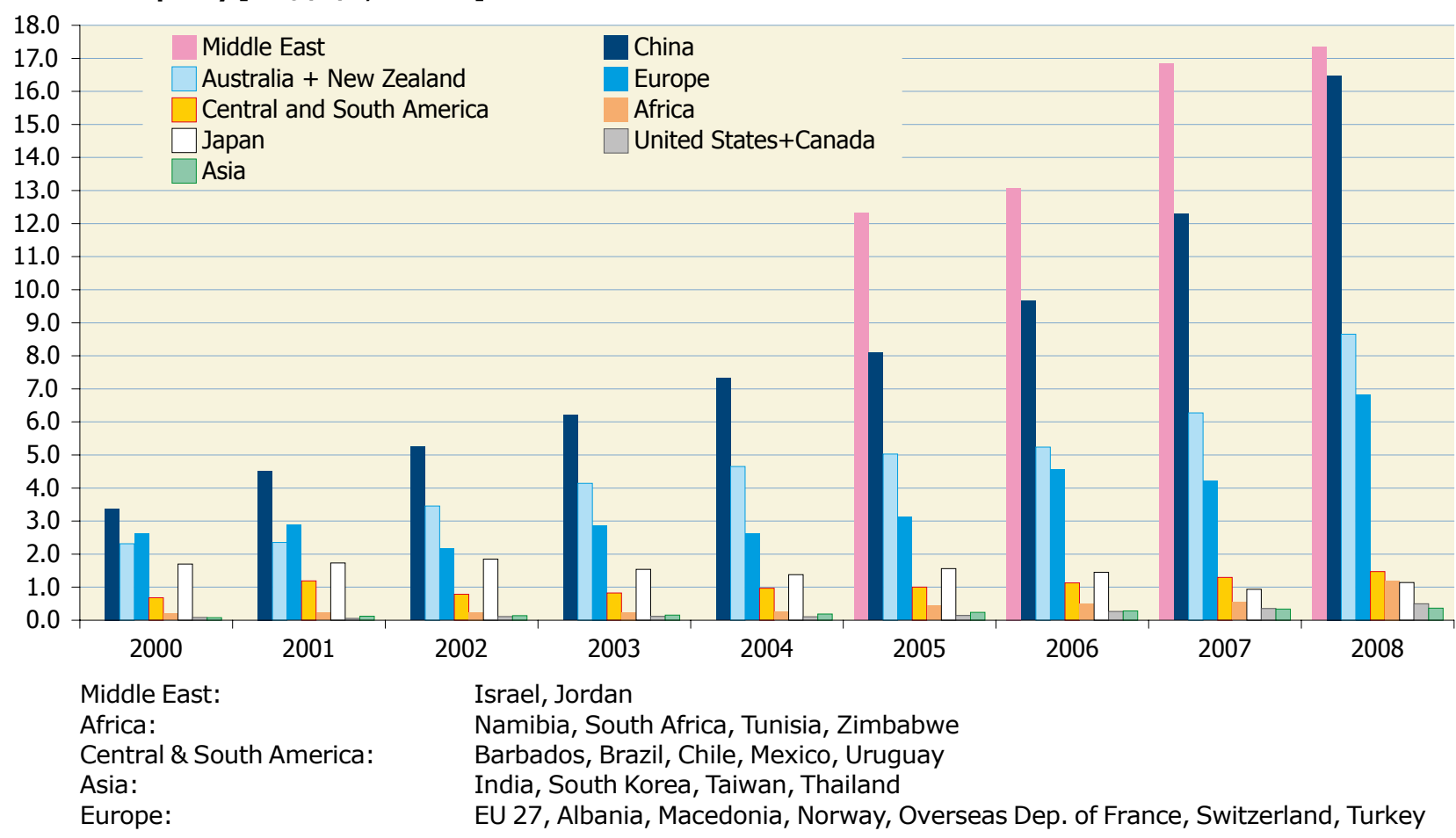

Figure 18: Annually installed capacity of flat-plate and evacuated tube collectors

in $\mathrm{kW}_{\text {th }}$ per 1,000 inhabitants from 2000 to 2008

Besides Israel and Jordan, the Chinese market led in terms of specific collector area installed (capacity/inhabitant), although China loses absolute dominance due to its large population. 


\subsection{Market development of unglazed water collectors by economic region}

In the United States and Australia, unglazed collectors play an important role. In other large markets, such as China, Turkey, India and Japan, unglazed collectors almost do not exist. In Europe, the annual installations of unglazed collectors remain at a fairly constant level of around $80 \mathrm{MW}_{\text {th }}$ per year and around $45 \mathrm{MW}_{\text {th }}$ per year in the reported African countries.

The worldwide market of unglazed collectors for swimming pool heating recorded an increase in 2000 and remained steady between 2001 and 2003. After a slight increase from 2004 to 2006 the installed capacity rate decreased again in 2007, mainly due to the major market decline in the United States and Canada (see Figure 19).

In 2008, a significant growth was recorded Canada and South Africa. All other markets remained quite stable.

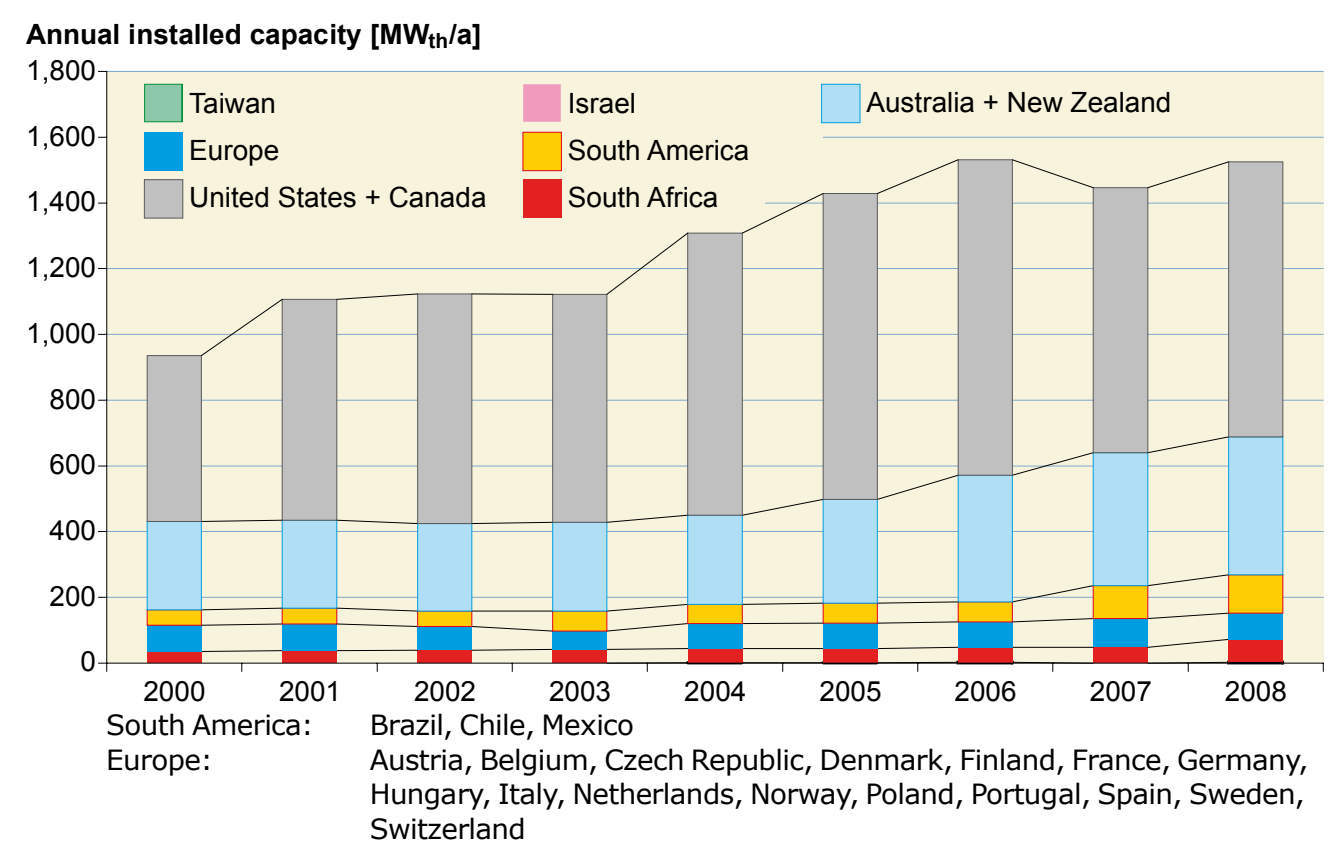

Figure 19: Annual installed capacity of unglazed water collectors from 2000 to 2008 


\section{Contribution to the energy supply and $\mathrm{CO}_{2}$ reduction}

In this section, the contribution of installed water collectors to the energy supply and $\mathrm{CO}_{2}$ reduction is shown. The data for air collector applications was insufficient; therefore, the contribution of air collectors to the energy supply and $\mathrm{CO}_{2}$ reduction was not calculated.

The basis for these calculations is the total collector area in operation in each country. As shown in Table 1, flat-plate and evacuated tube collector capacity was $131.8 \mathrm{GW}_{\text {th }}$ and unglazed plastic collector capacity was $18.9 \mathrm{GW}_{\text {th }}$ for installed collectors at the end of the year 2008 in the recorded countries.

The annual collector yield was $109,713 \mathrm{GWh}(394,968 \mathrm{TJ})$. This corresponds to an oil equivalent of 12.4 million tons and an annual avoidance of 39.4 million tons of $\mathrm{CO}_{2}$.

The methodology for the calculation of the annual collector yield is described in detail in the Annex (see chapter 7.1).

Table 5 summarizes the calculated annual collector yields and the corresponding oil equivalents and $\mathrm{CO}_{2}$ reductions of all solar thermal systems (systems for hot water, space heating and swimming pool heating) installed by the end of 2008.

Table 6 and Table 7 show the results for glazed water collectors and unglazed swimming pool collectors respectively. 


\begin{tabular}{|c|c|c|c|c|c|c|c|}
\hline \multirow[b]{2}{*}{ Country } & \multicolumn{7}{|c|}{ Total glazed (flate plate and evacuated tube collectors) and unglazed Water Collectors } \\
\hline & $\begin{array}{c}\text { Total } \\
\text { collector } \\
\text { area }\left[\mathrm{m}^{2}\right]\end{array}$ & $\begin{array}{c}\text { Total } \\
\text { capacity } \\
{\left[\mathrm{MW}_{\text {th }}\right]}\end{array}$ & $\begin{array}{c}\text { Calculated } \\
\text { number of } \\
\text { systems }\end{array}$ & $\begin{array}{l}\text { Collector } \\
\text { yield } \\
\text { [GWh/a] }\end{array}$ & $\begin{array}{c}\text { Collector } \\
\text { yield } \\
{[\mathrm{TJ} / \mathrm{a}]}\end{array}$ & $\begin{array}{c}\text { Energy } \\
\text { savings: Oil } \\
\text { equivalent [t/a] }\end{array}$ & $\begin{array}{c}\mathrm{CO}_{2} \\
\text { reduction } \\
{[\mathrm{t} / \mathrm{a}]}\end{array}$ \\
\hline Albania & 57,619 & 40.3 & 6,845 & 40.5 & 146.0 & 5,074 & 16,089 \\
\hline Australia & $6,098,000$ & $4,268.6$ & 490,377 & 2,992.1 & $10,771.5$ & 351,958 & $1,113,857$ \\
\hline Austria & $3,964,354$ & $2,775.0$ & 389,599 & $1,311.7$ & $4,722.0$ & 154,720 & 490,722 \\
\hline Barbados & 82,104 & 57.5 & 20,526 & 61.2 & 220.4 & 6,252 & 19,804 \\
\hline Belgium & 274,508 & 192.2 & 57,143 & 93.2 & 335.4 & 11,247 & 35,621 \\
\hline Brazil & $4,293,206$ & $3,005.2$ & 764,218 & $2,704.4$ & $9,735.7$ & 298,904 & 946,384 \\
\hline Bulgaria & 30,336 & 21.2 & 5,579 & 13.8 & 49.7 & 1,761 & 5,568 \\
\hline Canada & 980,865 & 575.4 & 19,038 & 310.1 & $1,116.5$ & 31,667 & 99,893 \\
\hline Chile & 19,200 & 13.4 & 4,440 & 12.2 & 44.0 & 1,620 & 5,131 \\
\hline China & $125,000,000$ & $87,500.0$ & $28,493,750$ & $62,893.8$ & $226,417.6$ & $7,145,526$ & $22,616,779$ \\
\hline Cyprus & 803,520 & 562.5 & 167,614 & 624.4 & $2,248.0$ & 69,169 & 218,698 \\
\hline Czech Republic & 156,298 & 109.4 & 23,478 & 51.9 & 186.8 & 6,040 & 19,130 \\
\hline Denmark & 454,829 & 303.5 & 90,326 & 167.1 & 601.6 & 19,929 & 63,107 \\
\hline Estonia & 1,891 & 1.3 & 473 & 0.7 & 2.5 & 81 & 256 \\
\hline Finland & 36,240 & 25.4 & 5,893 & 12.9 & 46.4 & 1,464 & 4,638 \\
\hline France & $1,866,240$ & $1,306.4$ & 352,803 & 748.3 & $2,693.9$ & 94,372 & 298,875 \\
\hline Germany & $11,071,754$ & $7,726.7$ & $1,397,411$ & $3,834.6$ & $13,804.5$ & 470,477 & $1,489,896$ \\
\hline Greece & $3,870,000$ & $2,709.0$ & 911,946 & $2,536.4$ & $9,131.1$ & 272,368 & 862,879 \\
\hline Hungary & 55,392 & 38.8 & 8,720 & 22.3 & 80.3 & 2,858 & 9,051 \\
\hline India & $2,547,515$ & $1,771.8$ & 458,146 & $1,941.1$ & $6,988.0$ & 219,839 & 697,657 \\
\hline 729 Ireland & 76,010 & 53.2 & 17,416 & 27.3 & 98.3 & 3,051 & 9,662 \\
\hline Israel & $3,800,000$ & $2,659.7$ & 925,998 & $3,402.6$ & $12,249.3$ & 355,354 & $1,125,664$ \\
\hline Italy & $1,474,819$ & $1,032.4$ & 362,526 & 780.2 & $2,808.7$ & 105,533 & 334,291 \\
\hline Japan & $6,315,500$ & $4,111.6$ & $1,421,813$ & $3,164.9$ & $11,393.7$ & 361,516 & $1,144,991$ \\
\hline Jordan & 893,065 & 625.1 & 174,898 & 723.5 & $2,604.6$ & 78,686 & 249,351 \\
\hline Korea & $1,427,834$ & 999.5 & 205,894 & 749.8 & $2,699.4$ & 89,386 & 284,463 \\
\hline Lativa & 6,864 & 4.8 & 1,716 & 2.7 & 9.8 & 313 & 992 \\
\hline Lithuania & 4,118 & 2.9 & 1,030 & 1.6 & 5.7 & 195 & 618 \\
\hline Luxembourg & 21,600 & 15.1 & 5,400 & 8.3 & 29.8 & 1,002 & 3,175 \\
\hline Macedonia & 22,742 & 15.9 & 4,901 & 11.7 & 42.0 & 1,541 & 4,884 \\
\hline Malta & 33,946 & 23.8 & 8,486 & 24.1 & 86.7 & 3,380 & 10,706 \\
\hline Mexico & $1,034,021$ & 723.8 & 47,842 & 480.9 & $1,731.4$ & 61,971 & 196,976 \\
\hline Namibia & 6,742 & 4.7 & 851 & 5.3 & 19.1 & 658 & 2,082 \\
\hline Netherlands & 703,741 & 492.6 & 100,361 & 205.8 & 740.9 & 23,030 & 72,961 \\
\hline New Zealand & 134,550 & 94.2 & 30,562 & 71.5 & 257.5 & 9,038 & 28,635 \\
\hline Norway & 14,966 & 9.7 & 1,998 & 5.1 & 18.3 & 590 & 1,869 \\
\hline Poland & 356,188 & 245.6 & 41,441 & 128.8 & 463.7 & 15,924 & 50,443 \\
\hline Portugal & 354,172 & 247.9 & 84,157 & 225.5 & 811.9 & 31,412 & 99,549 \\
\hline Romania & 74,496 & 52.1 & 18,624 & 36.8 & 132.6 & 4,834 & 15,312 \\
\hline Slovak Republic & 107,246 & 75.1 & 17,874 & 44.5 & 160.2 & 5,742 & 18,061 \\
\hline trightSlovenia & 122,698 & 85.9 & 18,556 & 44.6 & 160.6 & 5,666 & 17,837 \\
\hline South Africa & 975,360 & 682.8 & 72,419 & 584.5 & $2,104.3$ & 59,754 & 189,154 \\
\hline Spain & $1,641,600$ & $1,149.1$ & 240,970 & 994.7 & $3,581.0$ & 129,021 & 408,835 \\
\hline Sweden & 381,000 & 266.7 & 22,275 & 118.3 & 426.0 & 13,406 & 42,427 \\
\hline Switzerland & $1,596,710$ & 526.2 & 73,461 & 250.9 & 903.2 & 29,075 & 92,077 \\
\hline Taiwan & $1,697,686$ & $1,188.4$ & 417,499 & 918.4 & $3,306.2$ & 101,780 & 322,393 \\
\hline Thailand & 76,742 & 53.7 & 19,185 & 52.0 & 187.4 & 5,378 & 17,037 \\
\hline Tunisia & 286,080 & 200.3 & 69,546 & 227.0 & 817.2 & 24,135 & 76,445 \\
\hline Turkey & $10,636,800$ & $7,445.8$ & $2,487,948$ & $7,880.4$ & $28,369.5$ & 879,984 & $2,786,683$ \\
\hline United Kingdom & 370,483 & 259.3 & 92,621 & 128.8 & 463.8 & 16,439 & 52,077 \\
\hline United States & $20,614,290$ & $14,316.4$ & 542,787 & $8,024.9$ & $28,889.6$ & 842,893 & $2,670,575$ \\
\hline Uruguay & 4,861 & 3.4 & 1,215 & 2.8 & 9.9 & 377 & 1,195 \\
\hline Zimbabwe & 17,316 & 12.1 & 4,329 & 12.1 & 43.7 & 1,777 & 5,628 \\
\hline TOTAL & $216,948,117$ & $150,683.5$ & $41,204,925$ & $109,713.4$ & $394,968.2$ & $12,428,168$ & $39,351,084$ \\
\hline
\end{tabular}

Table 5: Calculated annual collector yield and corresponding oil equivalent as well as $\mathrm{CO}_{2}$ reduction of all solar thermal systems (systems for hot water, space heating and swimming pool heating) installed by the end of 2008. 


\begin{tabular}{|c|c|c|c|c|c|c|c|}
\hline \multirow[b]{2}{*}{ Country } & \multicolumn{7}{|c|}{ Glazed (flate plate and evacuated tube collectors) Water Collectors } \\
\hline & $\begin{array}{c}\text { Total } \\
\text { collector } \\
\text { area }\left[\mathrm{m}^{2}\right]\end{array}$ & $\begin{array}{c}\text { Total } \\
\text { capacity } \\
{\left[\mathrm{MW}_{\text {th }}\right]}\end{array}$ & $\begin{array}{c}\text { Calculated } \\
\text { number of } \\
\text { systems }\end{array}$ & $\begin{array}{l}\text { Collector } \\
\text { yield } \\
\text { [GWh/a] }\end{array}$ & $\begin{array}{c}\text { Collector } \\
\text { yield } \\
{[\mathrm{TJ} / \mathrm{a}]}\end{array}$ & $\begin{array}{c}\text { Energy } \\
\text { savings: Oil } \\
\text { equivalent [t/a] }\end{array}$ & $\begin{array}{c}\mathrm{CO}_{2} \\
\text { reduction } \\
{[\mathrm{t} / \mathrm{a}]}\end{array}$ \\
\hline Albania & 57,619 & 40.3 & 6,845 & 40.5 & 146.0 & 5,074 & 16,089 \\
\hline Australia & $1,998,000$ & $1,398.6$ & 470,697 & $1,258.6$ & $4,530.9$ & 181,687 & 575,516 \\
\hline Austria & $3,340,244$ & $2,338.2$ & 386,479 & $1,140.0$ & $4,103.9$ & 137,944 & 437,401 \\
\hline Barbados & 82,104 & 57.5 & 20,526 & 61.2 & 220.4 & 6,252 & 19,804 \\
\hline Belgium & 227,633 & 159.3 & 56,908 & 81.5 & 293.5 & 10,106 & 32,012 \\
\hline Brazil & $3,490,377$ & $2,443.3$ & 760,204 & $2,443.5$ & $8,796.5$ & 273,278 & 865,368 \\
\hline Bulgaria & 30,336 & 21.2 & 5,579 & 13.8 & 49.7 & 1,761 & 5,568 \\
\hline Canada & 96,728 & 67.7 & 15,412 & 47.4 & 170.5 & 5,774 & 18,283 \\
\hline Chile & 17,730 & 12.4 & 4,433 & 11.4 & 41.1 & 1,540 & 4,877 \\
\hline China & $125,000,000$ & $87,500.0$ & $28,493,750$ & $62,893.8$ & $226,417.6$ & $7,145,526$ & $22,616,779$ \\
\hline Cyprus & 803,520 & 562.5 & 167,614 & 624.4 & $2,248.0$ & 69,169 & 218,698 \\
\hline Czech Republic & 141,677 & 99.2 & 23,405 & 47.7 & 171.7 & 5,629 & 17,827 \\
\hline Denmark & 413,050 & 289.1 & 90,224 & 161.2 & 580.2 & 19,343 & 61,264 \\
\hline Estonia & 1,891 & 1.3 & 473 & 0.7 & 2.5 & 81 & 256 \\
\hline Finland & 24,461 & 17.1 & 5,834 & 9.3 & 33.5 & 1,113 & $3, \overline{524}$ \\
\hline France & $1,765,920$ & $1,236.1$ & 352,301 & 716.2 & $2,578.4$ & 91,212 & 288,910 \\
\hline Germany & $10,318,154$ & $7,222.7$ & $1,393,811$ & $3,614.2$ & $13,010.9$ & 448,704 & $1,421,438$ \\
\hline Greece & $3,870,000$ & $2,709.0$ & 911,946 & $2,536.4$ & $9,131.1$ & 272,368 & 862,879 \\
\hline Hungary & 52,704 & 36.9 & 8,707 & 21.5 & 77.2 & 2,773 & 8,784 \\
\hline India & $2,531,195$ & $1,771.8$ & 458,146 & $1,941.1$ & $6,988.0$ & 219,839 & 697,657 \\
\hline Ireland & 76,010 & 53.2 & 17,416 & 27.3 & 98.3 & 3,051 & 9,662 \\
\hline Israel & $3,772,878$ & $2,641.0$ & 925,864 & $3,388.4$ & $12,198.4$ & 353,964 & $1,121,269$ \\
\hline Italy & $1,449,600$ & $1,014.7$ & 362,400 & 769.7 & $2,771.1$ & 104,506 & 331,045 \\
\hline Japan & $5,873,644$ & $4,111.6$ & $1,421,813$ & $3,164.9$ & $11,393.7$ & 361,516 & $1,144,991$ \\
\hline Jordan & 893,065 & 625.1 & 174,898 & 723.5 & $2,604.6$ & 78,686 & 249,351 \\
\hline Korea & $1,427,834$ & 999.5 & 205,894 & 749.8 & $2,699.4$ & 89,386 & 284,463 \\
\hline Lativa & 6,864 & 4.8 & 1,716 & 2.7 & 9.8 & 313 & 992 \\
\hline Lithuania & 4,118 & 2.9 & 1,030 & 1.6 & 5.7 & 195 & 618 \\
\hline Luxembourg & 21,600 & 15.1 & 5,400 & 8.3 & 29.8 & 1,002 & 3,175 \\
\hline Macedonia & 22,742 & 15.9 & 4,901 & 11.7 & 42.0 & 1,541 & 4,884 \\
\hline Malta & 33,946 & 23.8 & 8,486 & 24.1 & 86.7 & 3,380 & 10,706 \\
\hline Mexico & 537,430 & 376.2 & 45,359 & 336.6 & $1,211.7$ & 47,789 & 152,143 \\
\hline Namibia & 6,742 & 4.7 & 851 & 5.3 & 19.1 & 658 & 2,082 \\
\hline Netherlands & 342,926 & 240.0 & 98,557 & 110.0 & 395.9 & 13,635 & 43,197 \\
\hline New Zealand & 128,006 & 89.6 & 30,529 & 68.9 & 248.0 & 8,780 & 27,817 \\
\hline Norway & 12,106 & 8.5 & 1,990 & 4.6 & 16.5 & 540 & 1,710 \\
\hline Poland & 349,660 & 244.8 & 41,435 & 128.5 & 462.4 & 15,890 & 50,335 \\
\hline Portugal & 352,831 & 247.0 & 84,150 & 225.0 & 810.0 & 31,360 & 99,385 \\
\hline Romania & 74,496 & 52.1 & 18,624 & 36.8 & 132.6 & 4,834 & 15,312 \\
\hline Slovak Republic & 107,246 & 75.1 & 17,874 & 44.5 & 160.2 & 5,742 & 18,061 \\
\hline 9 Slovenia & 122,698 & 85.9 & 18,556 & 44.6 & 160.6 & 5,666 & 17,837 \\
\hline South Africa & 275,682 & 193.0 & 68,920 & 252.2 & 908.0 & 27,135 & 85,954 \\
\hline Spain & $1,555,200$ & $1,088.6$ & 240,538 & 956.8 & $3,444.4$ & 125,284 & 397,050 \\
\hline Sweden & 276,000 & 193.2 & 21,771 & 89.1 & 320.7 & 10,527 & 33,347 \\
\hline Switzerland & 539,910 & 377.9 & 72,402 & 194.0 & 698.6 & 23,470 & 74,420 \\
\hline Taiwan & $1,695,827$ & $1,187.1$ & 417,490 & 917.8 & $3,304.3$ & 101,726 & 322,222 \\
\hline Thailand & 76,742 & 53.7 & 19,185 & 52.0 & 187.4 & 5,378 & 17,037 \\
\hline Tunisia & 286,080 & 200.3 & 69,546 & 227.0 & 817.2 & 24,135 & 76,445 \\
\hline Turkey & $10,636,800$ & $7,445.8$ & $2,487,948$ & $7,880.4$ & $28,369.5$ & 879,984 & $2,786,683$ \\
\hline United Kingdom & 370,483 & 259.3 & 92,621 & 128.8 & 463.8 & 16,439 & 52,077 \\
\hline United States & $2,724,910$ & $1,907.4$ & 454,152 & $1,491.7$ & $5,370.2$ & 202,589 & 641,678 \\
\hline Uruguay & 4,861 & 3.4 & 1,215 & 2.8 & 9.9 & 377 & 1,195 \\
\hline Zimbabwe & 17,316 & 12.1 & 4,329 & 12.1 & 43.7 & 1,777 & 5,628 \\
\hline TOTAL & $188,339,594$ & $131,837.7$ & $41,071,153$ & 99,746.1 & $359,085.9$ & $11,450,425$ & $36,255,707$ \\
\hline
\end{tabular}

Table 6: Calculated annual collector yield and corresponding oil equivalent as well as $\mathrm{CO}_{2}$ reduction of solar thermal systems using flat-plate and evacuated tube collectors (for example hot water preparation and space heating, low temperature industrial process heat) installed by the end of 2008 


\begin{tabular}{|c|c|c|c|c|c|c|c|}
\hline \multirow[b]{2}{*}{ Country } & \multicolumn{7}{|c|}{ Unglazed Water Collectors (swimming pool collectors) } \\
\hline & $\begin{array}{c}\text { Total } \\
\text { collector } \\
\text { area }\left[\mathrm{m}^{2}\right]\end{array}$ & $\begin{array}{c}\text { Total } \\
\text { capacity } \\
\text { [MWth] }\end{array}$ & $\begin{array}{c}\text { Calculated } \\
\text { number of } \\
\text { systems }\end{array}$ & $\begin{array}{c}\text { Collector } \\
\text { yield } \\
{[G W h / a]}\end{array}$ & $\begin{array}{c}\text { Collector } \\
\text { yield } \\
{[\mathrm{T} J / \mathrm{a}]}\end{array}$ & $\begin{array}{l}\text { Energy } \\
\text { savings: Oil } \\
\text { equivalent } \\
\text { tons/a] }\end{array}$ & $\begin{array}{c}\mathrm{CO}_{2} \\
\text { reduction } \\
{[\mathrm{t} / \mathrm{a}]}\end{array}$ \\
\hline \multicolumn{8}{|l|}{ Albania } \\
\hline Australia & $4,100,000$ & $2,870.0$ & 19,680 & $1,733.5$ & $6,240.6$ & 170,271 & 538,341 \\
\hline Austria & 624,110 & 436.9 & 3,121 & 171.7 & 618.1 & 16,776 & 53,321 \\
\hline \multicolumn{8}{|l|}{ Barbados } \\
\hline Belgium & 46,875 & 32.8 & 234 & 11.6 & 41.8 & 1,142 & 3,609 \\
\hline Brazil & 802,830 & 562.0 & 4,014 & 260.9 & 939.2 & 25,626 & 81,016 \\
\hline \multicolumn{8}{|l|}{ Bulgaria } \\
\hline Canada & 725,277 & 507.7 & 3,626 & 262.8 & 946.0 & 25,892 & 81,610 \\
\hline Chile & 1,470 & 1.0 & 7 & 0.8 & 2.9 & 80 & 254 \\
\hline \multicolumn{8}{|l|}{ China } \\
\hline \multicolumn{8}{|l|}{ Cyprus } \\
\hline Czech Republic & 14,621 & 10.2 & 73 & 4.2 & 15.1 & 411 & 1,303 \\
\hline Denmark & 20,515 & 14.4 & 103 & 5.9 & 21.4 & 586 & 1,843 \\
\hline \multicolumn{8}{|l|}{ Estonia } \\
\hline Finland & 11,779 & 8.2 & 59 & 3.6 & 12.9 & 351 & 1,113 \\
\hline France & 100,320 & 70.2 & 502 & 32.1 & 115.5 & 3,160 & 9,965 \\
\hline Germany & 720,000 & 504.0 & 3,600 & 220.4 & 793.6 & 21,773 & 68,457 \\
\hline \multicolumn{8}{|l|}{ Greece } \\
\hline parHungary & 2,688 & 1.9 & 13 & 0.9 & 3.1 & 85 & 267 \\
\hline \multicolumn{8}{|l|}{ India } \\
\hline \multicolumn{8}{|l|}{ Ireland } \\
\hline Israel & 26,700 & 18.7 & 134 & 14.2 & 51.0 & 1,391 & 4,395 \\
\hline Italy & 25,219 & 17.7 & 126 & 10.5 & 37.6 & 1,027 & 3,246 \\
\hline \multicolumn{8}{|l|}{ Japan } \\
\hline \multicolumn{8}{|l|}{ Jordan } \\
\hline \multicolumn{8}{|l|}{ Korea } \\
\hline \multirow{2}{*}{\multicolumn{8}{|c|}{ Lativa }} \\
\hline & \multirow{2}{*}{\multicolumn{3}{|c|}{ Lithuania }} & & & & \\
\hline \multirow{2}{*}{\multicolumn{6}{|c|}{$\begin{array}{l}\text { Luxembourg } \\
\text { Macedonia }\end{array}$}} & & \\
\hline & & & & & & & \\
\hline Malta & & & & & & & \\
\hline Mexico & 496,591 & 347.6 & 2,483 & 144.4 & 519.7 & 14,183 & 44,833 \\
\hline Namibia & & & & & & & \\
\hline Netherlands & 360,815 & 252.6 & 1,804 & 95.8 & 345.0 & 9,396 & 29,763 \\
\hline New Zealand & 6,544 & 4.6 & 33 & 2.6 & 9.5 & 258 & 818 \\
\hline Norway & 1,709 & 1.2 & 9 & 0.5 & 1.8 & 50 & 159 \\
\hline Poland & 1,248 & 0.9 & 6 & 0.3 & 1.2 & 34 & 108 \\
\hline Portugal & 1,340 & 0.9 & 7 & 0.5 & 1.9 & 52 & 164 \\
\hline Romania & & & & & & & \\
\hline Slovak Republic & & & & & & & \\
\hline Slovenia & & & & & & & \\
\hline South Africa & 699,678 & 489.8 & 3,498 & 332.3 & $1,196.3$ & 32,619 & 103,199 \\
\hline Spain & 86,400 & 60.5 & 432 & 37.9 & 136.6 & 3,738 & 11,785 \\
\hline Sweden & 105,000 & 73.5 & 504 & 29.2 & 105.3 & 2,879 & 9,080 \\
\hline Switzerland & 211,800 & 148.3 & 1,059 & 56.9 & 204.7 & 5,604 & 17,658 \\
\hline Taiwan & 1,860 & 1.3 & 9 & 0.5 & 2.0 & 54 & 170 \\
\hline Thailand & & & & & & & \\
\hline Tunisia & & & & & & & \\
\hline Turkey & & & & & & & \\
\hline $\begin{array}{l}\text { United King- } \\
\text { dom }\end{array}$ & & & & & & & \\
\hline United States & $17,727,143$ & $12,409.0$ & 88,636 & $6,533.2$ & $23,519.4$ & 640,304 & $2,028,897$ \\
\hline Uruguay & & & & & & & \\
\hline Zimbabwe & & & & & & & \\
\hline TOTAL & $26,922,531$ & $18,845.8$ & 133,772 & $9,967.3$ & $35,882.3$ & 977,743 & $3,095,377$ \\
\hline
\end{tabular}

Table 7: Calculated annual collector yield and corresponding oil equivalent as well as $\mathrm{CO}_{2}$ reduction of solar thermal systems for swimming pool heating with unglazed collectors installed by the end of 2008. 


\subsection{Collector yield by economic region}

\subsubsection{Collector yield of glazed flat-plate and evacuated tube collectors by economic region}

Collector yield $[\mathrm{GWh} / \mathrm{a}]$

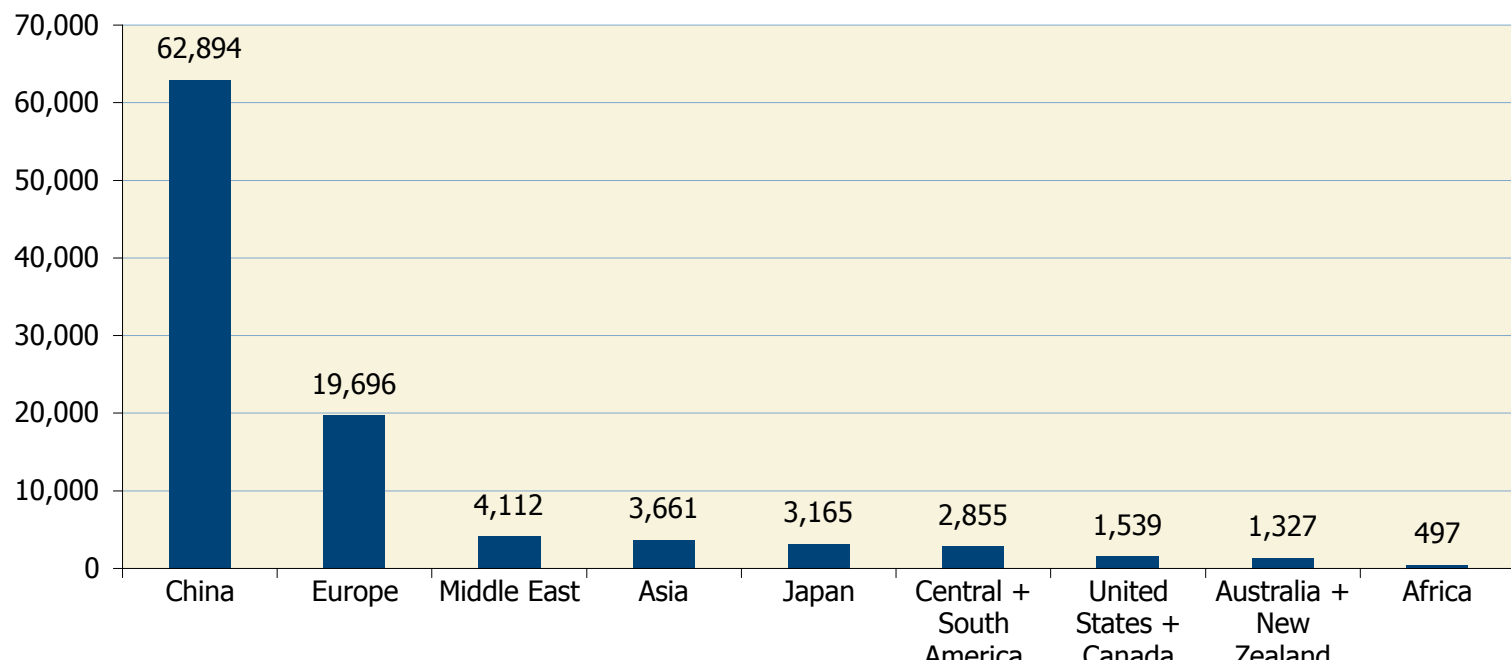

Middle East: $\quad$ Israel, Jordan

Africa: Namibia, South Africa, Tunisia, Zimbabwe

Central \& South America: Barbados, Brazil, Chile, Mexico, Uruguay

Asia: $\quad$ India, South Korea, Taiwan, Thailand

Europe: $\quad$ EU 27, Albania, Macedonia, Norway, Overseas Dep. of France, Switzerland, Turkey

Figure 20: Annual collector yield of glazed flat-plate and evacuated tube collectors in operation by economic region in 2008

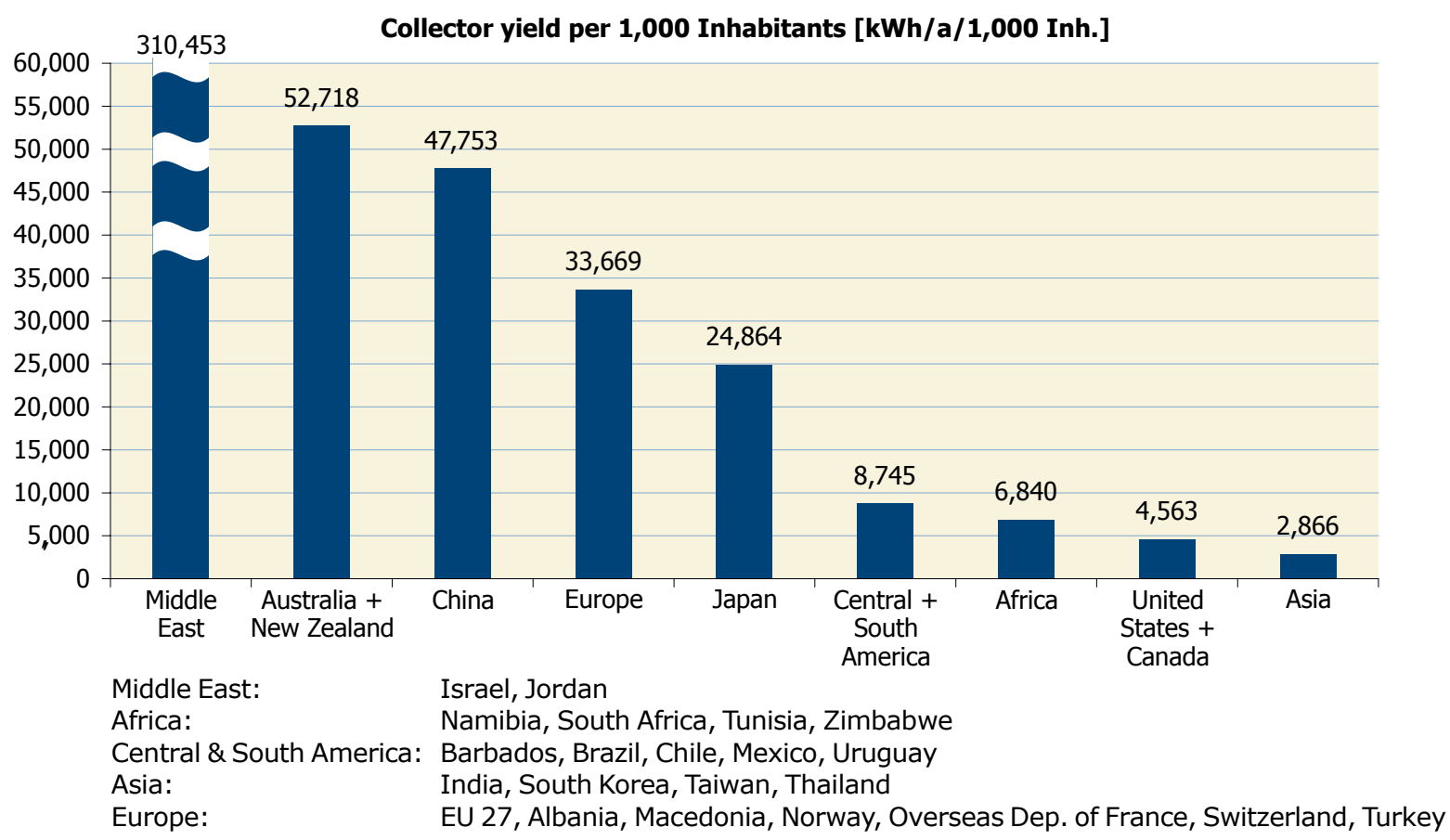

Figure 21: Annual collector yield of glazed flat-plate and evacuated tube collectors in operation by economic region at the end of 2008 in $\mathrm{kWh}$ per 1,000 inhabitants 


\subsubsection{Collector yield of unglazed collectors by economic region}

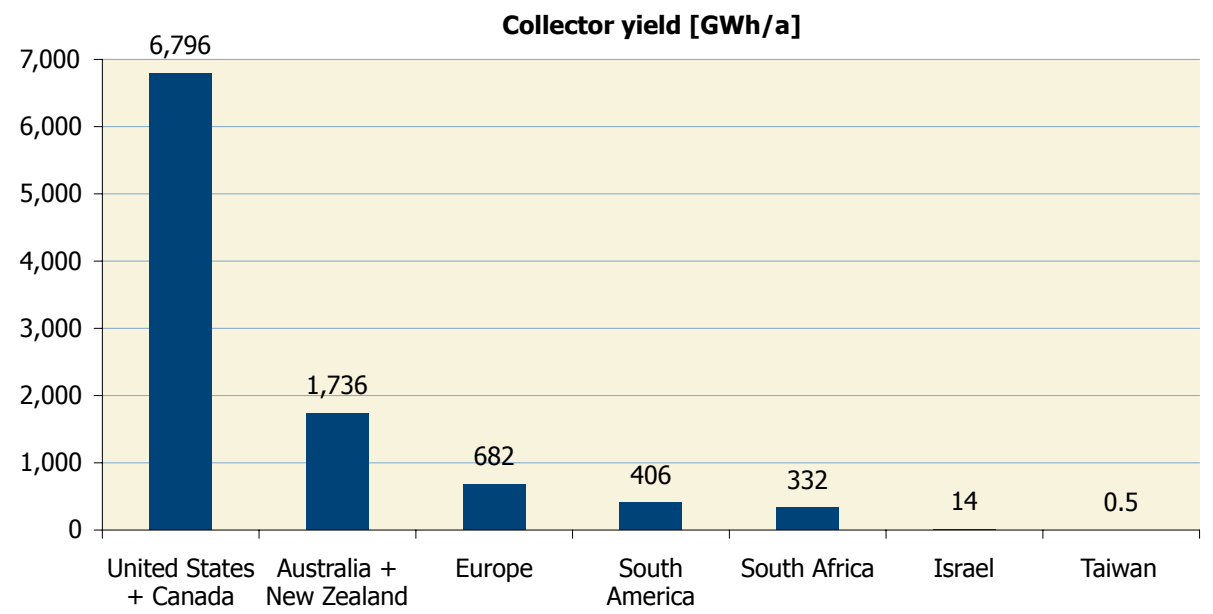

South America: Brazil, Chile, Mexico

Europe: $\quad$ Austria, Belgium, Czech Republic, Denmark, Finland, France, Germany, Hungary, Italy, Netherlands, Norway, Poland, Portugal, Spain, Sweden, Switzerland

Figure 22: Annual collector yield of unglazed collectors in operation by economic region at the end of 2008

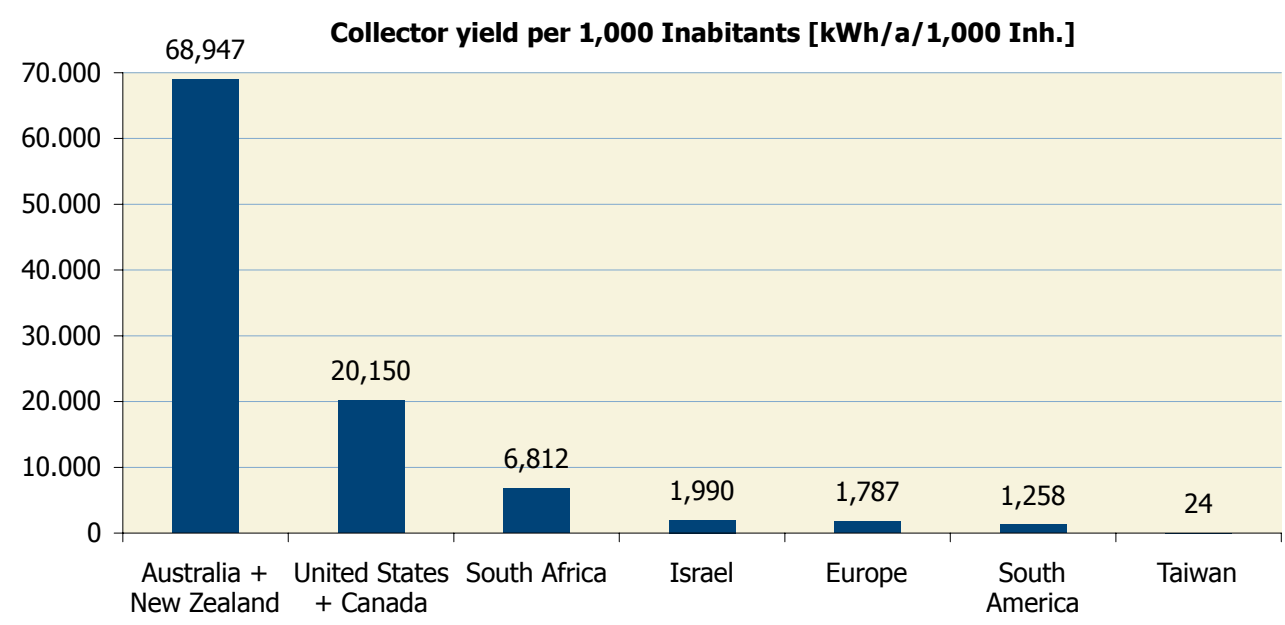

South America: $\quad$ Brazil, Chile, Mexico

Europe:

Austria, Belgium, Czech Republic, Denmark, Finland, France, Germany, Hungary, Italy, Netherlands, Norway, Poland, Portugal, Spain, Sweden, Switzerland

Figure 23: Annual collector yield of unglazed collectors in operation by economic region at the end of 2008 in $\mathrm{kWh}$ per 1,000 inhabitants 


\subsection{Energy savings by economic region}

\subsubsection{Energy savings in oil equivalent by glazed flat-plate and evacuated tube collectors by economic region}

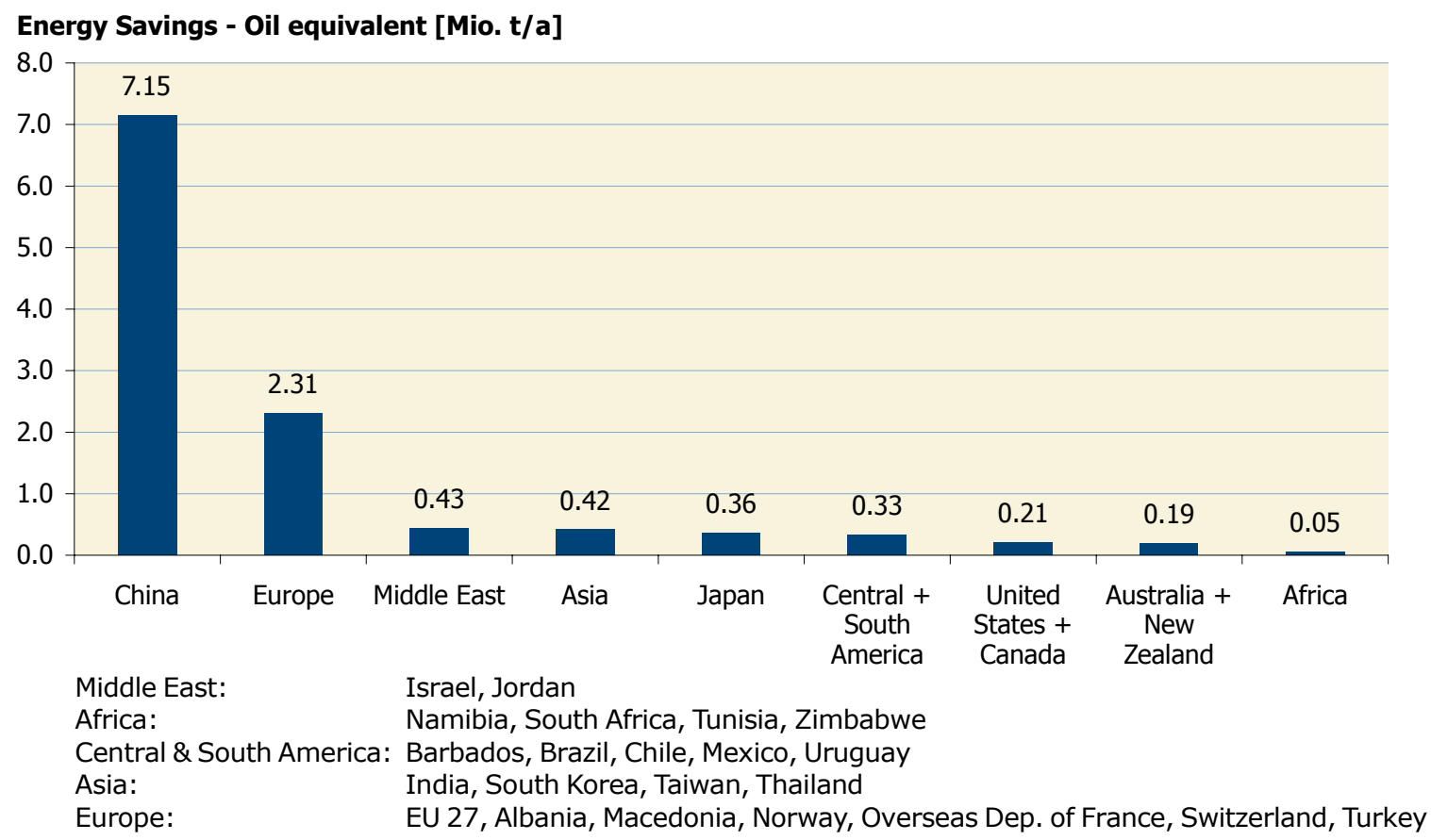

Figure 24: Annual energy savings in oil equivalent by glazed flat-plate and evacuated tube collectors by economic region at the end of 2008

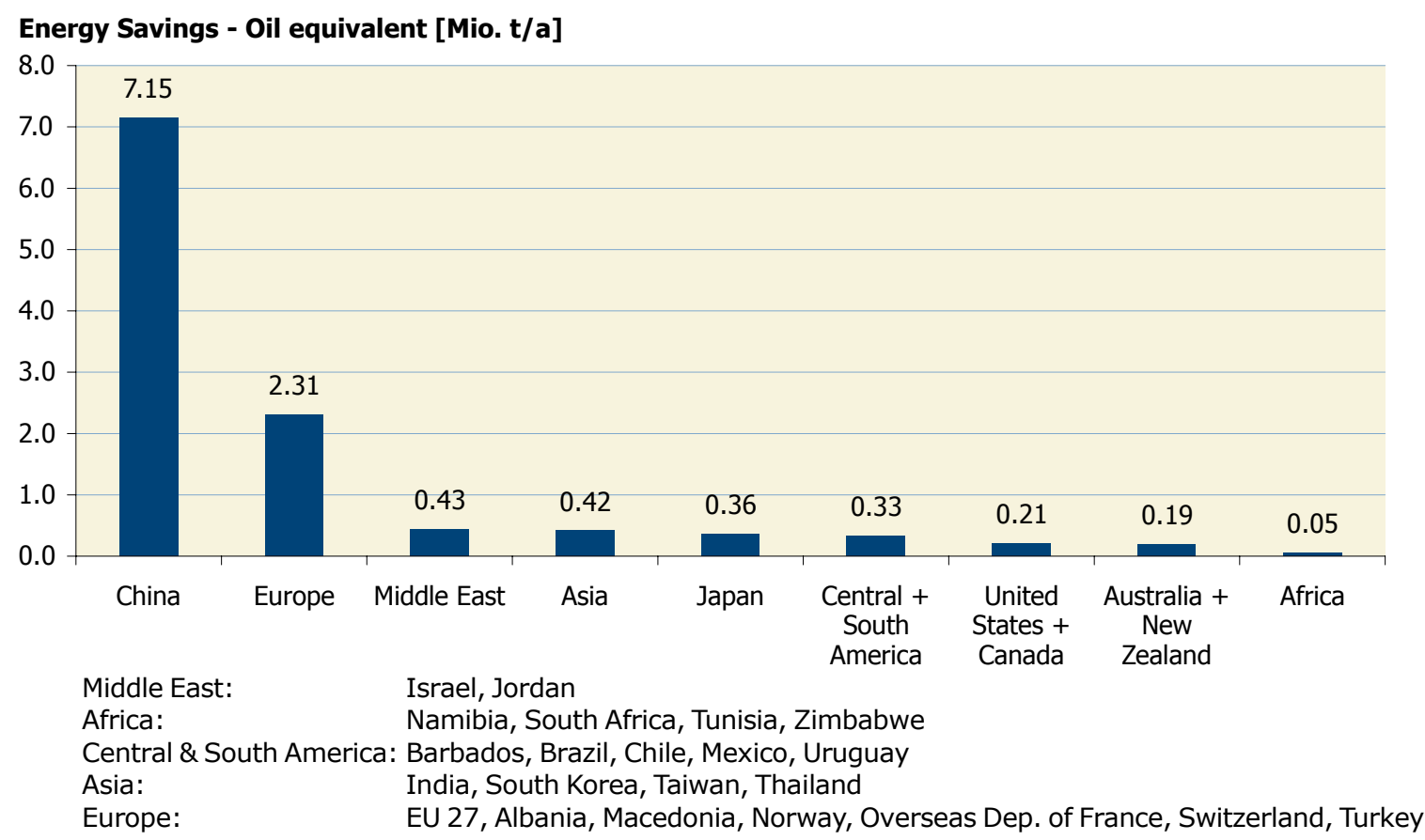

Figure 25: Annual energy savings in oil equivalent by glazed flat-plate and evacuated tube collectors in operation by economic region at the end of 2008 per 1,000 inhabitants 


\subsubsection{Energy savings in oil equivalent by unglazed collectors by economic region at the end of $\mathbf{2 0 0 8}$}

\section{Energy Savings: Oil equivalent $[t / a]$}

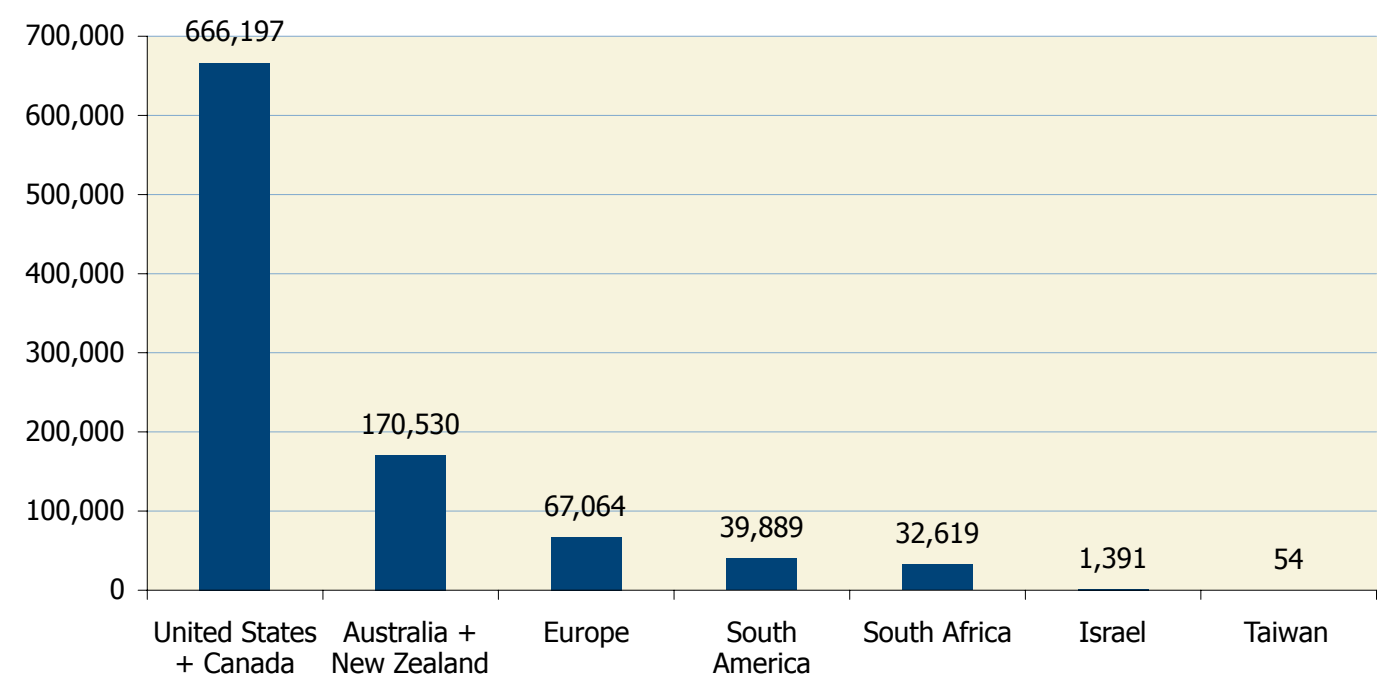

South America: Brazil, Chile, Mexico

Europe:

Austria, Belgium, Czech Republic, Denmark, Finland, France, Germany, Hungary, Italy, Netherlands, Norway, Poland, Portugal, Spain, Sweden, Switzerland

Figure 26: Annual energy savings in oil equivalent by unglazed collectors by economic region at the end of 2008

\section{Energy Savings: Oil equivalent per 1,000 Inhabitants [t/a/1,000 Inh.]}

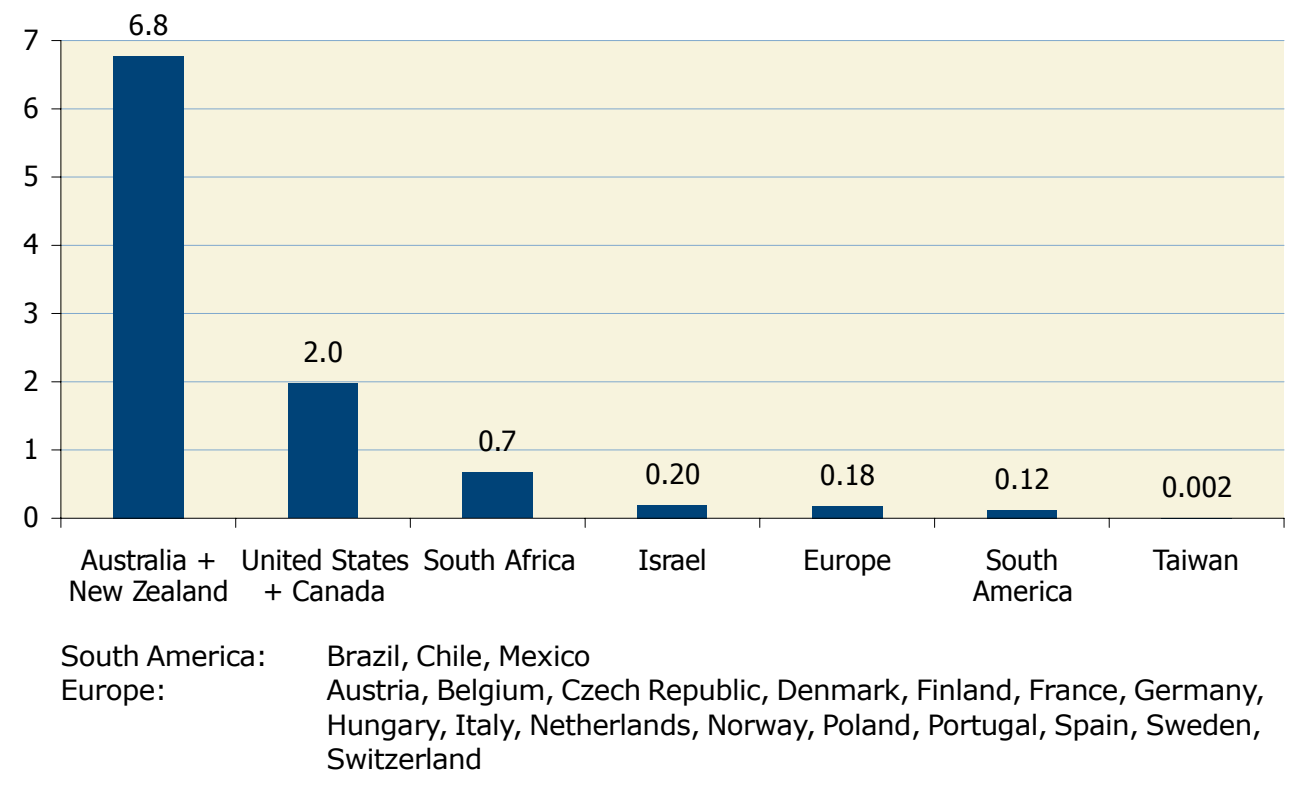

Figure 27: Annual energy savings in oil equivalent by unglazed collectors by economic region at the end of 2008 per 1,000 inhabitants 


\subsection{Contribution to $\mathrm{CO}_{2}$ reduction by economic region in 2008}

\subsubsection{Contribution to $\mathrm{CO}_{2}$ reduction by flat-plate and evacuated tube collectors by economic region in 2008}

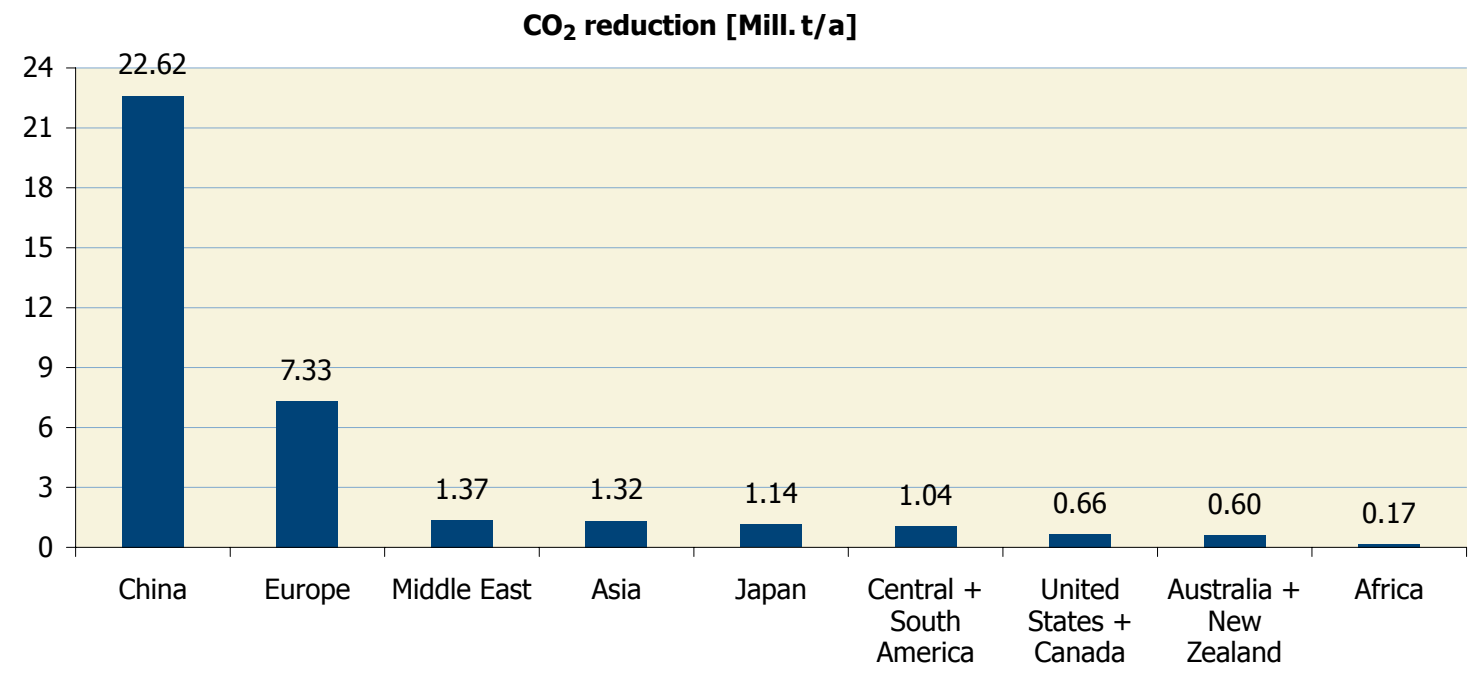

Middle East:

Israel, Jordan

Africa:

Namibia, South Africa, Tunisia, Zimbabwe

Central \& South America: Barbados, Brazil, Chile, Mexico, Uruguay

Asia:

India, South Korea, Taiwan, Thailand

Europe:

EU 27, Albania, Macedonia, Norway, Overseas Dep. of France, Switzerland, Turkey

Figure 28: Contribution to $\mathrm{CO}_{2}$ reduction by flat-plate and evacuated tube collectors by economic region in 2008

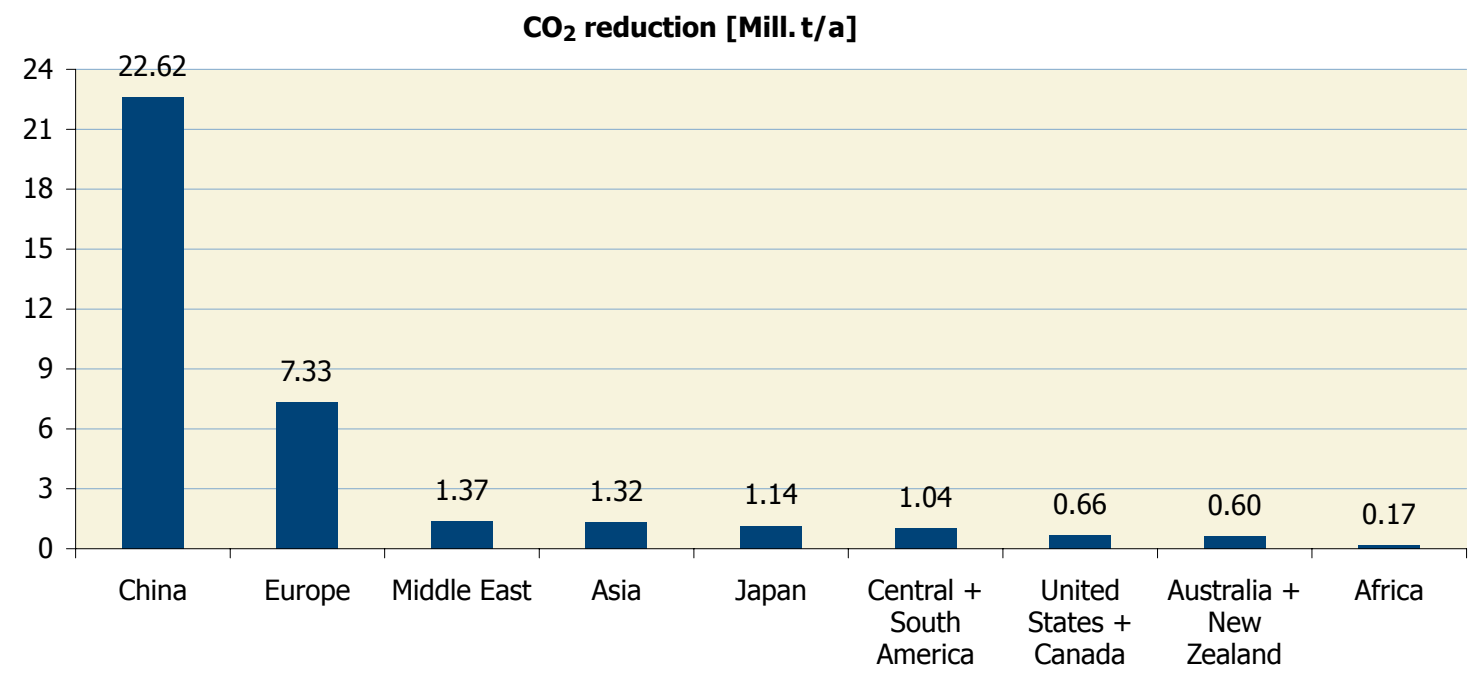

Middle East: $\quad$ Israel, Jordan

Africa: $\quad$ Namibia, South Africa, Tunisia, Zimbabwe

Central \& South America: Barbados, Brazil, Chile, Mexico, Uruguay

Asia: $\quad$ India, South Korea, Taiwan, Thailand

Europe: $\quad$ EU 27, Albania, Macedonia, Norway, Overseas Dep. of France, Switzerland, Turkey

Figure 29: Contribution to $\mathrm{CO}_{2}$ reduction by flat-plate and evacuated tube collectors

by economic region in 2008 per 1,000 inhabitants 


\subsubsection{Contribution to $\mathrm{CO}_{2}$ reduction by unglazed collectors by economic region in 2008}

\section{$\mathrm{CO}_{2}$ reduction $[$ Mill.t/a]}

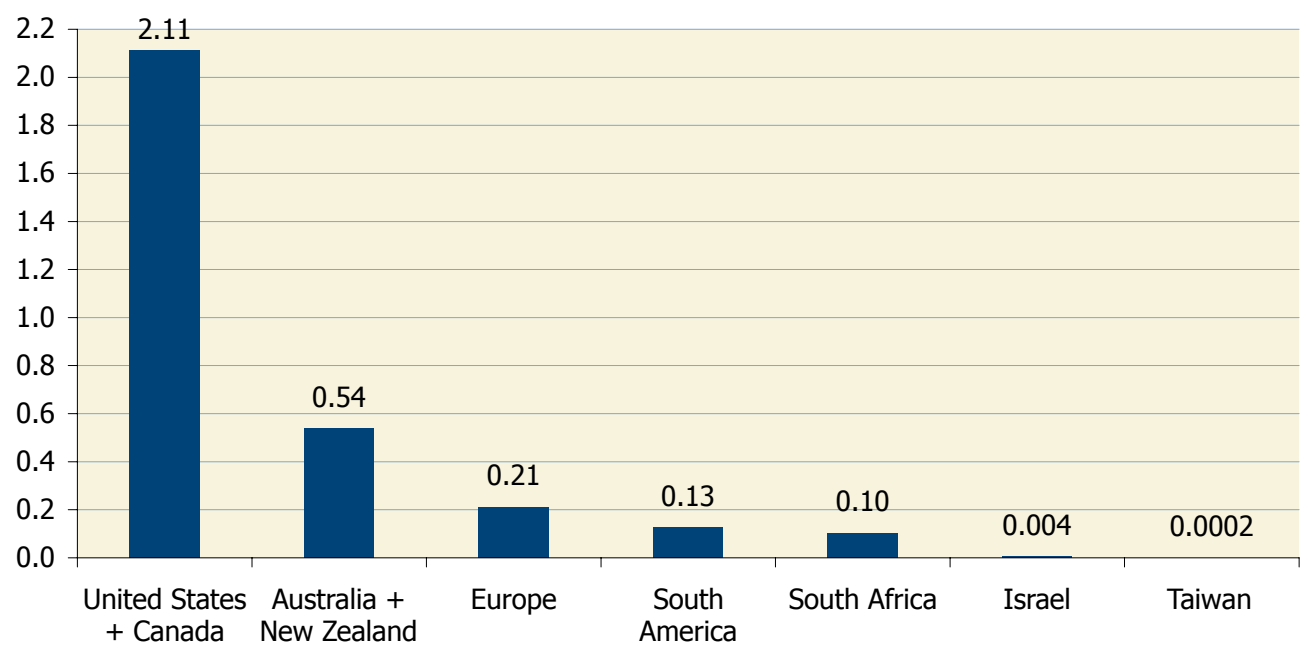

South America:

Brazil, Chile, Mexico

Europe:

Austria, Belgium, Czech Republic, Denmark, Finland, France, Germany, Hungary, Italy, Netherlands, Norway, Poland, Portugal, Spain, Sweden, Switzerland

Figure 30: Contribution to $\mathrm{CO}_{2}$ reduction by unglazed collectors by economic region in 2008

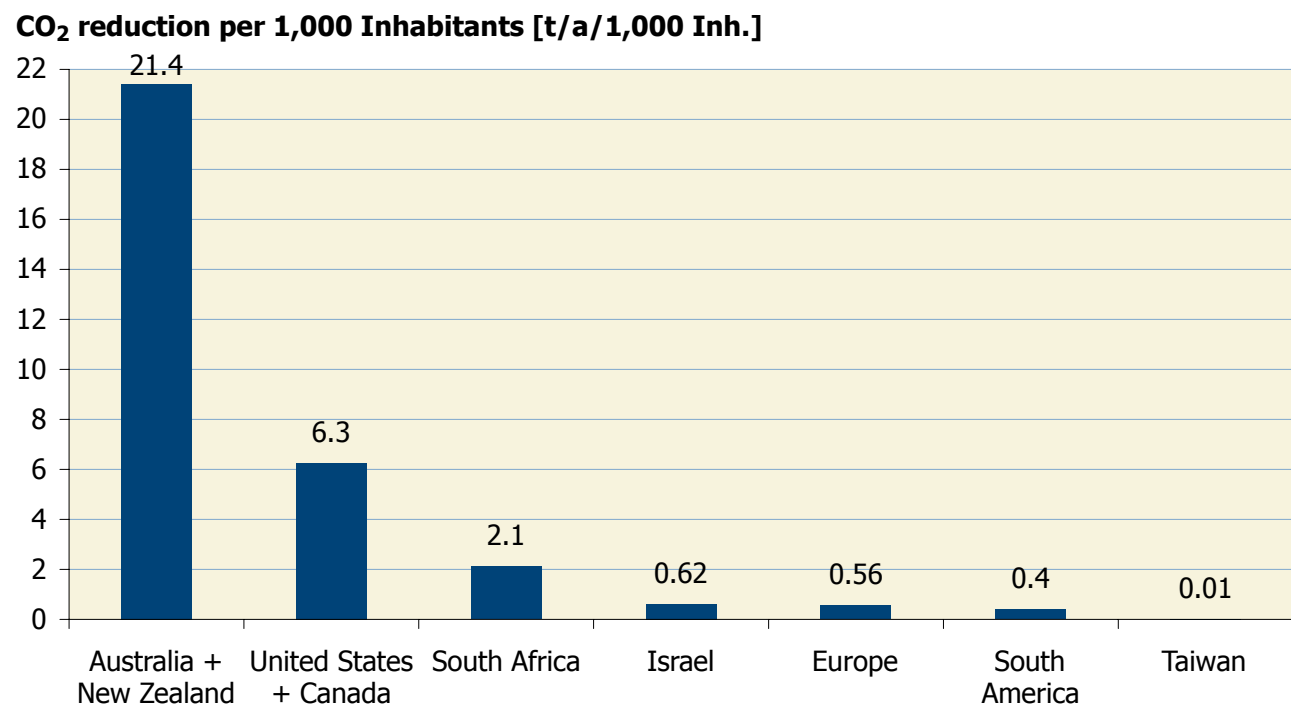

South America: $\quad$ Brazil, Chile, Mexico

Europe: Austria, Belgium, Czech Republic, Denmark, Finland, France, Germany, Hungary, Italy, Netherlands, Norway, Poland, Portugal, Spain, Sweden, Switzerland

Figure 31: Contribution to $\mathrm{CO}_{2}$ reduction by unglazed collectors by economic region in 2008 per 1,000 inhabitants 


\section{Distribution of systems by application}

\subsection{Distribution by application-total capacity in operation}

If one observes the use of solar thermal energy, it becomes clear that it greatly varies in the different countries. In China, Europe and Japan systems with flat-plate and evacuated tube collectors are mainly used to prepare hot water and to provide space heating while in North America (United States and Canada) swimming pool heating is the dominant application.

Another distinction can be made between pumped systems and thermosiphon systems as shown in Figure 32. In the United States, Europe and Australia mainly pumped systems are installed, whereas in Japan, Brazil and China thermosiphon systems are predominant.

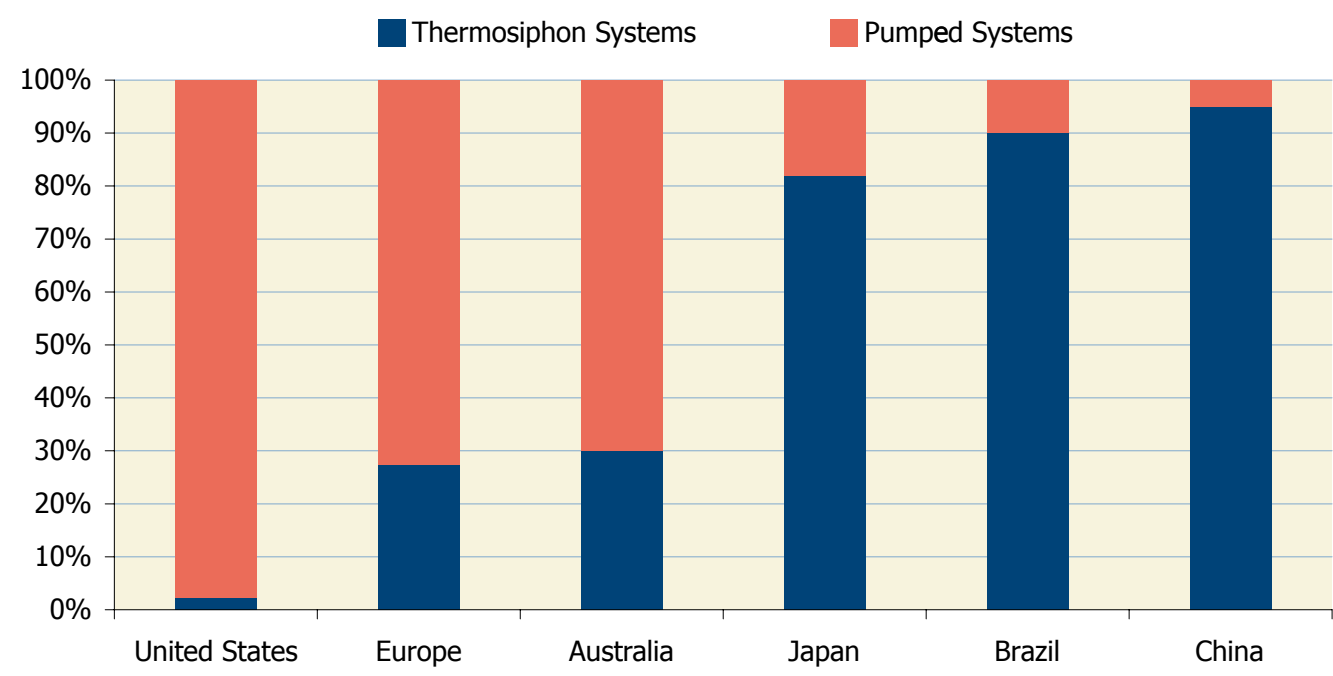

Europe:

Albania, Austria, Cyprus, Germany, Italy, Macedonia, Netherlands, Norway, Poland, Portugal, Slovenia, Spain, Sweden, Turkey

Figure 32: Distribution of different solar thermal systems by economic region for the total capacity in operation of glazed and evacuated tube collectors in 2008

Figure 33 shows the distribution of different applications in the total collector area in operation in the different economic regions. In this figure only applications with glazed flat-plate and evacuated tube collectors have been taken into consideration. Unglazed collectors and air collectors are not included.

The figure shows the dominance of systems that are installed to produce hot water for single-and multi-family houses. In addition, for some Asian, African and South American countries a remarkable amount of hot water systems for the public sector (e.g., hospitals, schools) have been reported.

The share of solar combi-systems for hot water preparation and space heating is only relevant in Europe and Japan. 


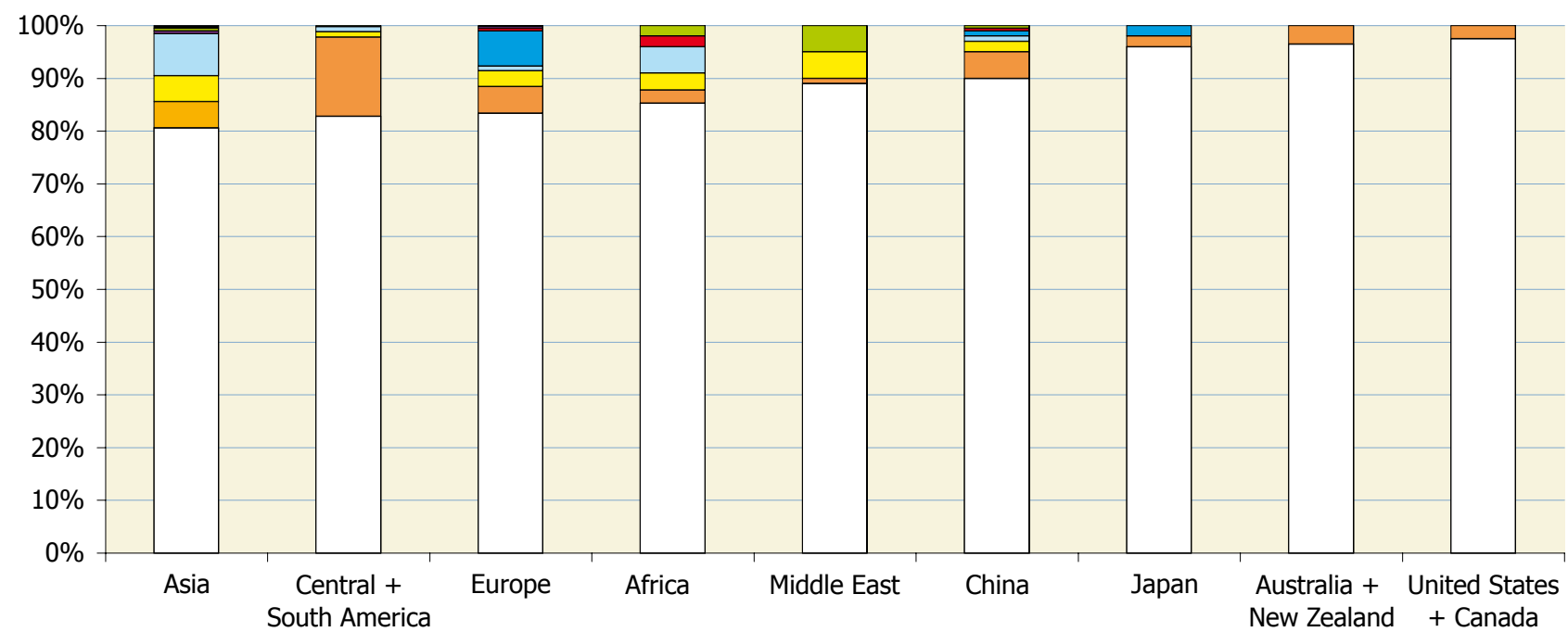

DHW System for single family houses

DHW System for the tourism sector (hotels. accomodations...)

Solar combi systems (DHW and space heating) for single

family houses

Solar district heating systems

Air conditioning and cooling
DHW System for multiple family houses

$\square$ DHW System for the public sector (hospitals. schools. homes for elderly people...)

Solar combi systems (DHW and space heating) for multiple family houses

Solar systems for industrial process heat
Middle East:

Africa:

Central \& South America:

Asia:

Europe:

DHW:
Israel, Jordan

Namibia, South Africa, Tunisia, Zimbabwe

Barbados, Brazil, Chile, Mexico, Uruguay

India, South Korea, Taiwan, Thailand

EU 27, Albania, Macedonia, Norway, Overseas Dep. of France, Switzerland, Turkey

Domestic Hot Water

Figure 33: Distribution of different applications by economic region for the total capacity in operation of glazed and evacuated tube collectors in 2008

Figure 34 shows the distribution of different applications for the top 10 countries in the world (in terms of installed capacity of glazed water collectors).

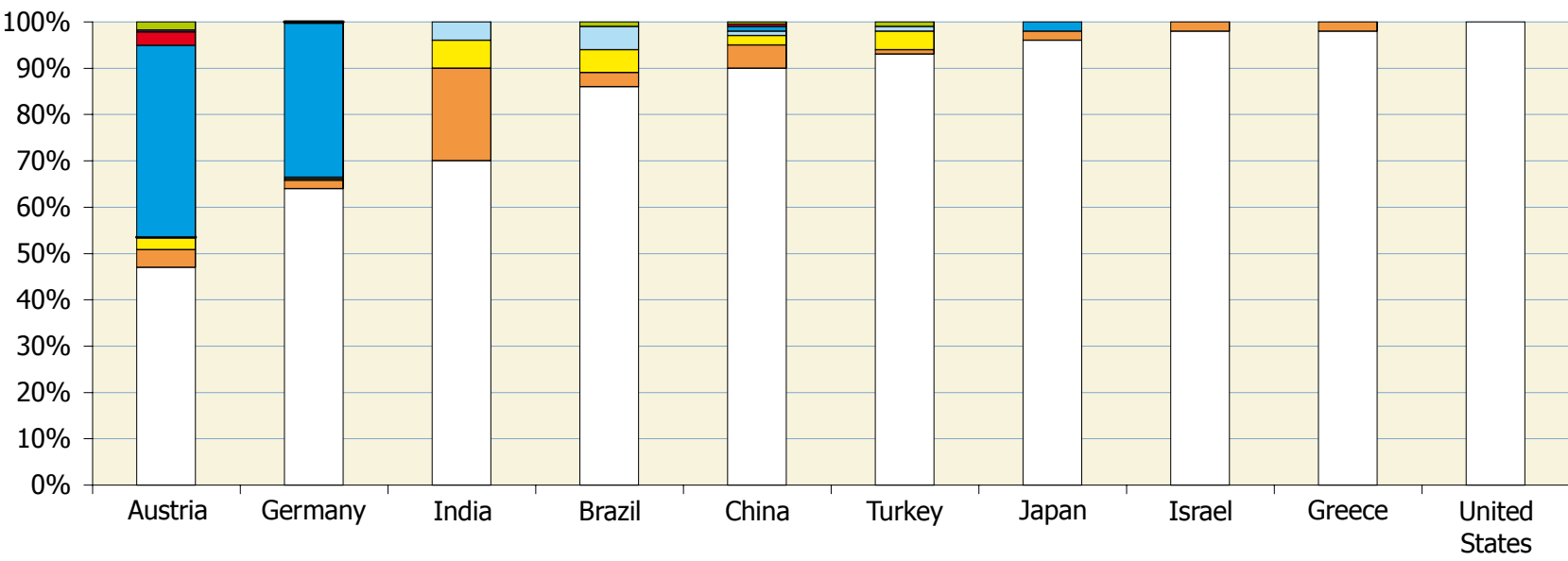

$\square$ DHW System for single family houses

$\square$ DHW System for the tourism sector (hotels. accomodations...)

Solar combi systems (DHW and space heating) for single family houses

- Solar district heating systems

Air conditioning and cooling

D HW: Domestic Hot Water
DHW System for multiple family houses

DHW System for the public sector (hospitals. schools. homes for elderly people...)

Solar combi systems (DHW and space heating) for multiple family houses

Solar systems for industrial process heat

Figure 34: Distribution of different applications of the world's top-10-countries related to the total capacity in operation of glazed and evacuated tube collectors in 2008 
It is remarkable that in Austria and Germany already about 30\% of the overall installations are solar combi-systems.

Worldwide, in Austria, France, Germany, Namibia, Slovenia, Sweden and Switzerland, the share of applications other than hot water preparation is equal to or higher than $15 \%$.

Figure 35 shows the distribution of the applications for the 10 countries in Europe with the largest collector areas in operation.

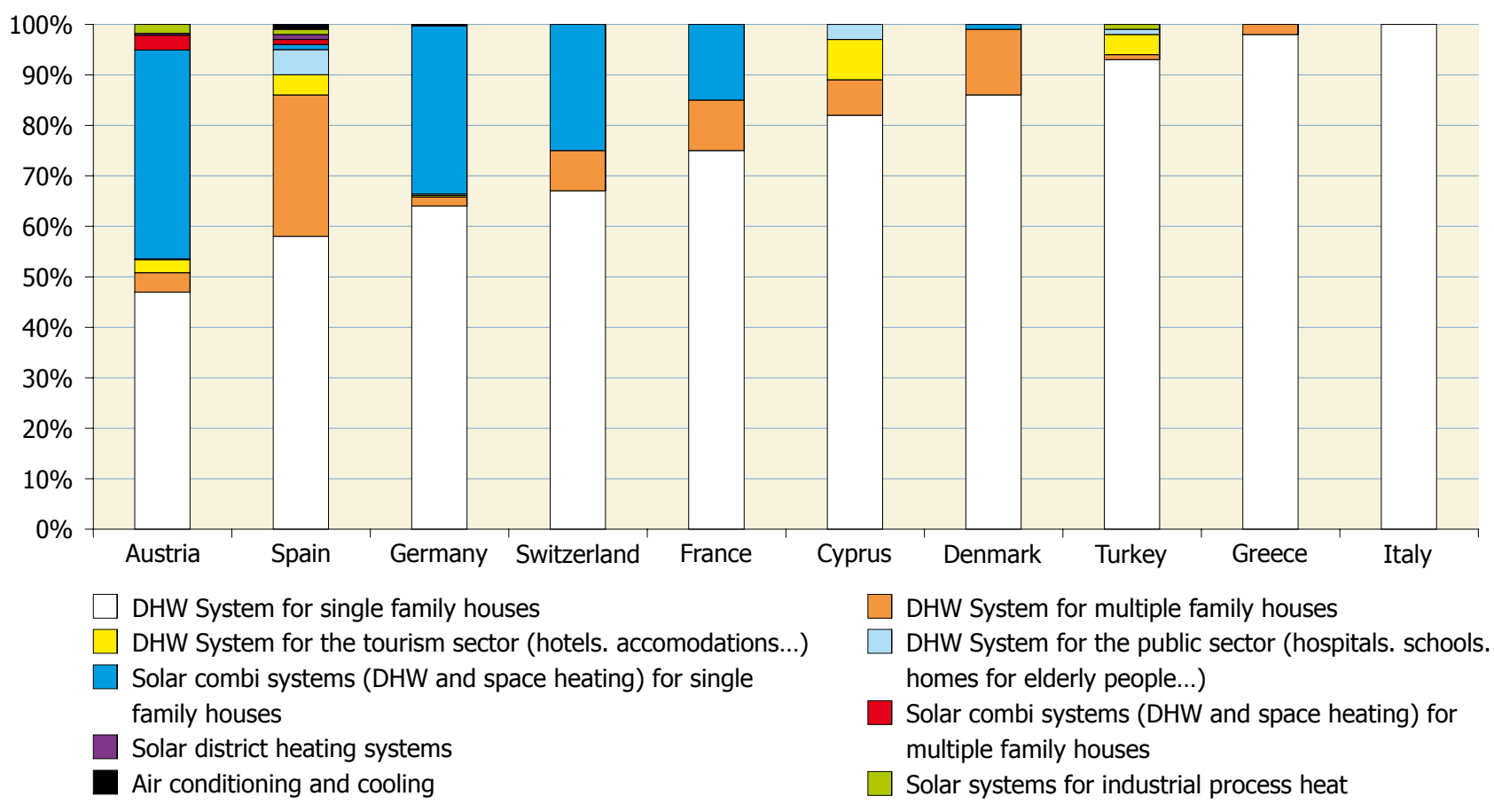

DHW: Domestic Hot Water

Figure 35: Distribution of different applications in the European top-10-countries related to the total capacity in operation of glazed and evacuated tube collectors in 2008

Spain, Austria and Germany have the most sophisticated markets for different solar thermal applications. It includes systems for hot water preparation, systems for space heating of single- and multi-family houses and hotels, largescale plants for district heating as well as a growing number of systems for air conditioning, cooling and industrial applications.

In general the large markets in Europe tend to become more sophisticated as a result of continuous R\&D activities. This can also be seen in Figure 36. 


\subsection{Distribution by application-systems installed in 2008}

In this chapter, the distribution of different solar thermal applications for newly installed systems in 2008 is presented. Figure 36 shows the distribution of different applications newly installed in 2008 by selected economic regions for glazed and evacuated tube collectors.

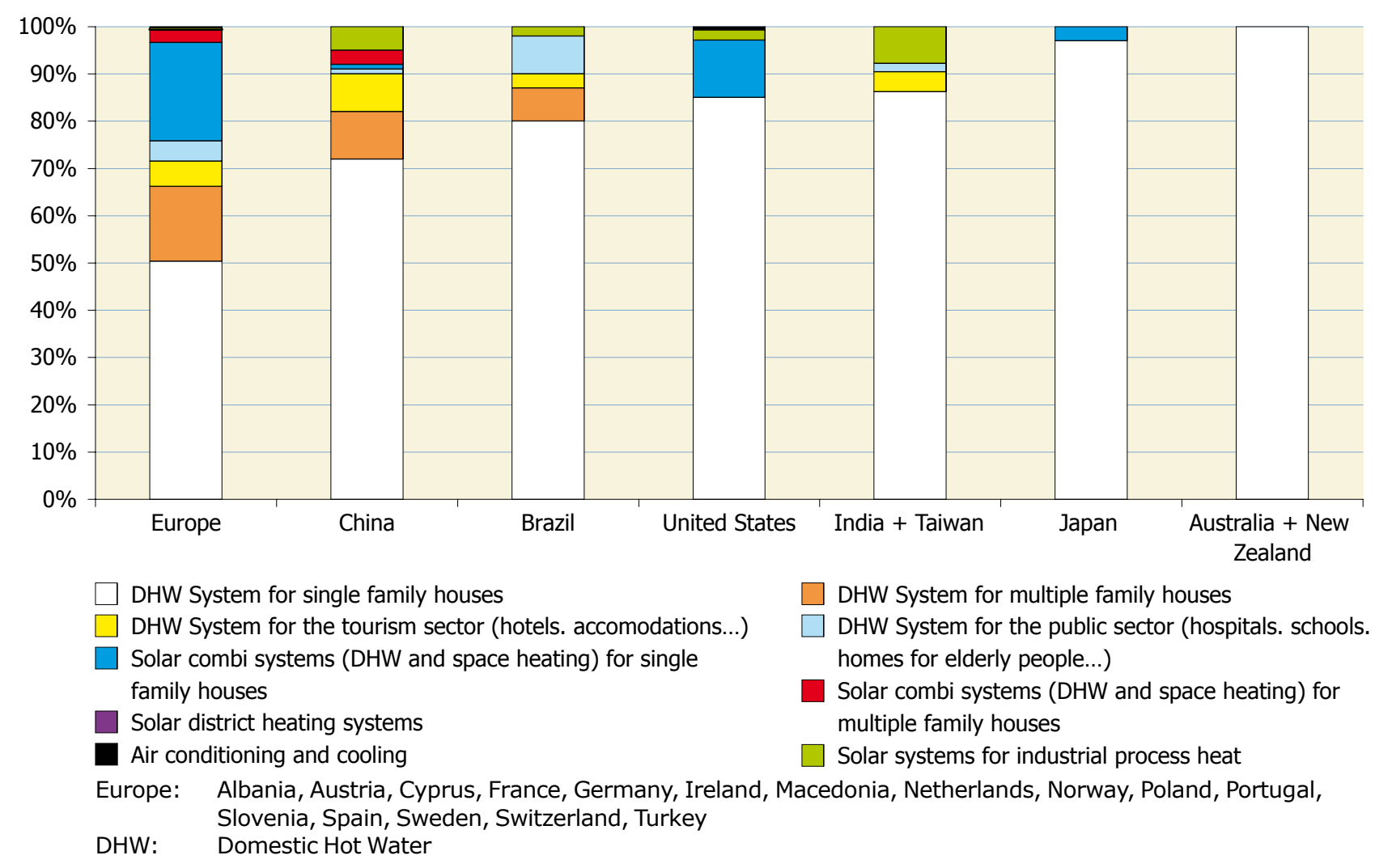

Figure 36: Distribution of different applications newly installed in 2008 by economic region for glazed and evacuated tube collectors

Figure 36 shows the dominance of systems installed to produce hot water for single-family houses. However, in Europe there were almost as many conventional domestic hot water installations than installations for other applications. This development can be explained by analyzing the top 8 markets of new installations in 2008 as shown in Figure 37. 


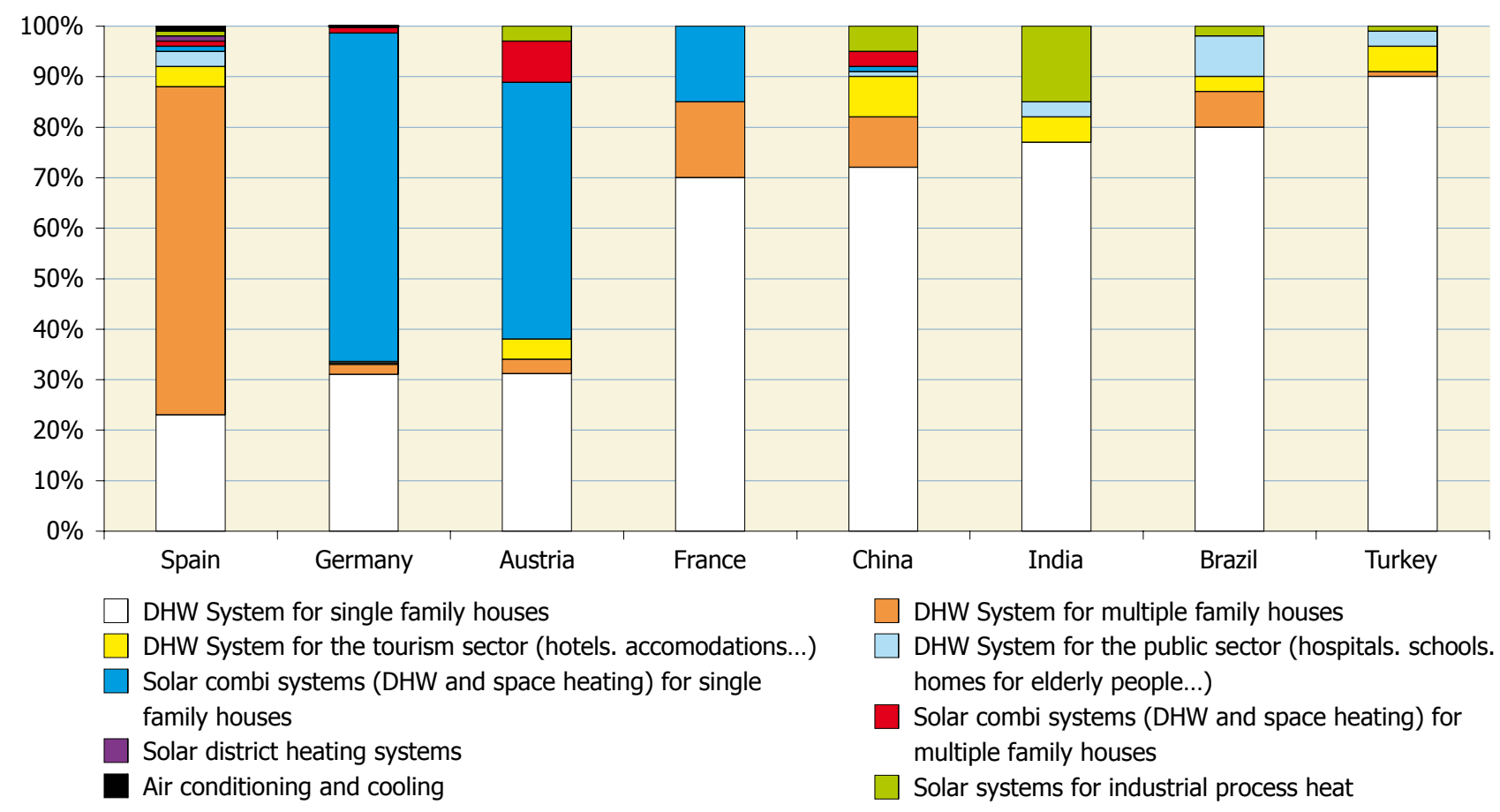

Figure 37: Distribution of different applications of the world's top-8-countries related to the newly installed capacity of glazed and evacuated tube collectors in 2008

It is notable that in the large European solar thermal markets, Spain, Germany and Austria domestic hot water systems only accounted for about $30 \%$ or less of the total installed systems in 2008. 


\section{Appendix}

\subsection{Methodological approach for the energy calculation}

In order to obtain the energy yield of thermal solar plants, the oil equivalent saved and the $\mathrm{CO}_{2}$ emissions avoided, the following procedure was used:

- Only water collectors were used for the calculations (unglazed, flat-plate and evacuated tube collectors). Air collector plants were not considered.

- For each country, the overall collector area installed (water collectors) was allocated to the four plant types:

- Solar thermal systems for swimming pool heating with unglazed collectors

Solar domestic hot water systems for single family houses

- Solar domestic hot water systems for multi-family houses, hotels and district heating

- Solar combi systems ${ }^{2}$ for domestic hot water and space heating for single and multiple family houses

- Reference plants were defined for each country and for each type of plant.

- The number of plants for each country was determined from the share of collector area for each plant type and the collector area per reference system.

Reference collectors and a reference climate were determined for each country apart from the reference plants. On the basis of these reference conditions, simulations were performed with the simulation program T-Sol [T-Sol, Version 4.5 Expert, Valentin Energiesoftware, www.valentin.de] to obtain the solar yields, energy savings and $\mathrm{CO}_{2}$ emissions.

The annual collector yield per square meter of collector area, depending on the application (swimming pool heating, domestic hot water preparation, space heating etc.), the local climatic conditions and the plant dimensions (high or low solar fraction) was calculated for each country and each system. The energy savings were obtained from the energy equivalent of the fuel used and the rate of efficiency of the auxiliary heating system.

For the auxiliary heating system, oil was taken as the fuel for all plants and the energy equivalent per liter of fuel oil $38,052 \mathrm{~kJ}$ (higher heating value) respectively $10.57 \mathrm{kWh}$ was used in all countries in order to achieve comparable results.

To obtain an exact statement about the $\mathrm{CO}_{2}$ emissions avoided, the substituted energy medium would have to be ascertained for each country. Since this could only be done in a very detailed survey, which goes beyond the scope of this report, the energy savings and the $\mathrm{CO}_{2}$ emissions avoided relate to fuel oil.

It is obvious that not all solar thermal systems worldwide just replace systems running on oil. This represents a simplification since gas, coal, biomass or electricity can be used as the energy source for the auxiliary heating system instead of oil.

The $\mathrm{CO}_{2}$ emissions avoided by solar systems were ascertained from the energy savings (oil equivalent). As the emission factor $2.79 \mathrm{~kg} \mathrm{CO}_{2} /$ I was used.

The following tables describe the key data of the reference systems in the different countries, the location of the reference climate used and the share of the total collector area in use for the respective application. Furthermore, a hydraulic scheme is shown for each reference system.

2 Solar combi-systems are solar heating installations that provide space heating and domestic hot water. 
7.1.1 Solar thermal systems for swimming pool heating with unglazed collectors

\begin{tabular}{|c|c|c|c|c|}
\hline Country & Reference climate & $\begin{array}{c}\text { Collector area } \\
\text { (gross area) for } \\
\text { single system [m²] }\end{array}$ & $\begin{array}{c}\text { Total collector area } \\
\text { unglazed 2008 } \\
{\left[\mathrm{m}^{2}\right]}\end{array}$ & $\begin{array}{c}\text { Total number } \\
\text { of systems } \\
\text { unglazed } 2008\end{array}$ \\
\hline Australia & Sydney & 200 & $4,100,000$ & 19,680 \\
\hline Austria & Graz & 200 & 624,110 & 3,121 \\
\hline Belgium & Brussels & 200 & 46,875 & 234 \\
\hline Brazil & Brasília & 200 & 802,830 & 4,014 \\
\hline Canada & Montreal & 200 & 725,277 & 3,626 \\
\hline Chile & Santiago de Chile & 200 & 1,470 & 7 \\
\hline Czech Republic & Praha & 200 & 14,621 & 73 \\
\hline Denmark & Copenhagen & 200 & 20,515 & 103 \\
\hline Finland & Helsinki & 200 & 11,779 & 59 \\
\hline France & Paris & 200 & 100,320 & 502 \\
\hline Germany & Würzburg & 200 & 720,000 & 3,600 \\
\hline Hungary & Budapest & 200 & 2,688 & 13 \\
\hline Israel & Jerusalem & 200 & 26,700 & 134 \\
\hline Italy & Bologna & 200 & 25,219 & 126 \\
\hline Mexico & Mexico City & 200 & 496,591 & 2,483 \\
\hline Netherlands & Amsterdam & 200 & 360,815 & 1,804 \\
\hline New Zealand & Wellington & 200 & 6,544 & 33 \\
\hline Norway & Oslo & 200 & 1,709 & 9 \\
\hline Poland & Warsaw & 200 & 1,248 & 6 \\
\hline Portugal & Lisbon & 200 & 1,340 & 7 \\
\hline South Africa & Johannesburg & 200 & 699,678 & 3,498 \\
\hline Spain & Madrid & 200 & 86,400 & 432 \\
\hline Sweden & Gothenburg & 200 & 105,000 & 504 \\
\hline Switzerland & Zürich & 200 & 211,800 & 1,059 \\
\hline Taiwan & Taipei & 200 & 1,860 & 9 \\
\hline United States & Indianapolis, Los Angeles & 200 & $17,727,143$ & 88,636 \\
\hline TOTAL & & & $26,922,531$ & 133,772 \\
\hline
\end{tabular}

* countries not listed in this table: no reliable database for unglazed collectors available

Table 8: Solar thermal swimming pool heating reference systems* and the total collector area in operation in 2008 (unglazed water collectors)

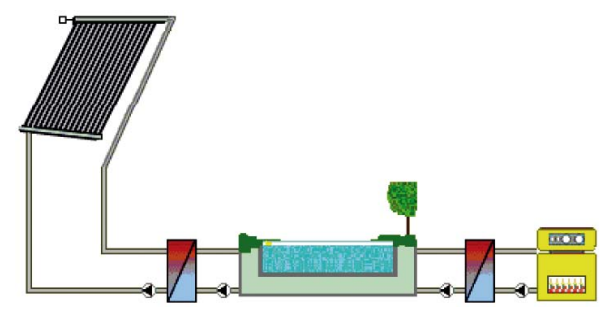

Figure 38: Hydraulic scheme of the swimming pool reference system

\subsubsection{Solar domestic hot water systems for single family houses}

The market share in the following table refers to the total capacity in operation of flat-plate and evacuated tube collectors at the end of 2008 for each country. It must be pointed out that the market share of the new installed capacity in the year 2008 can differ significantly from the total market share.

\begin{tabular}{|c|c|c|c|c|c|c|c|c|c|}
\hline \multirow[b]{2}{*}{ Country } & \multirow[b]{2}{*}{ Reference climate } & \multicolumn{2}{|c|}{ Collector area $\left[\mathrm{m}^{2}\right]$} & \multirow{2}{*}{$\begin{array}{c}\text { Share of } \\
\text { DHW- } \\
\text { SFH [\%] }\end{array}$} & \multirow{2}{*}{$\begin{array}{l}\text { Number of } \\
\text { systems } \\
\text { DHW-SFH }\end{array}$} & \multicolumn{2}{|c|}{ Hot water } & \multirow{2}{*}{$\begin{array}{c}\text { Storage } \\
\text { capacity } \\
{[I]}\end{array}$} & \multirow[b]{2}{*}{$\begin{array}{l}\text { Sys- } \\
\text { tem }\end{array}$} \\
\hline & & $\begin{array}{l}\text { for single } \\
\text { system }\end{array}$ & $\begin{array}{l}\text { total of DHW- } \\
\text { SFH } 2008\end{array}$ & & & $\begin{array}{c}\text { demand } \\
{[\mathrm{l} / \mathrm{d}]}\end{array}$ & temp. & & \\
\hline Albania & Tirana & 2.5 & 14,981 & 26 & 5,992 & 150 & 60 & 150 & TS \\
\hline Australia & Sydney & 4.0 & $1,958,040$ & 98 & 489,510 & 170 & 60 & 300 & PS \\
\hline Austria & Graz & 6.0 & $2,070,951$ & 62 & 345,159 & 150 & 60 & 300 & PS \\
\hline Barbados & Grantley Adams & 4.0 & 82,104 & 100 & 20,526 & 150 & 60 & 200 & TS \\
\hline Belgium & Brussels & 4.0 & 227,633 & 100 & 56,908 & 150 & 60 & 200 & PDS \\
\hline Brazil & Brasília & 4.0 & $3,001,724$ & 86 & 750,431 & 150 & 60 & 200 & TS \\
\hline Bulgaria & Sofia & 4.0 & 21,619 & 71 & 5,405 & 150 & 60 & 200 & PS \\
\hline Canada & Montreal & 6.0 & 91,891 & 95 & 15,315 & 150 & 60 & 200 & PS \\
\hline Chile & Santiago de Chile & 4.0 & 17,730 & 100 & 4,433 & 150 & 60 & 200 & PS \\
\hline China & Shanghai & 4.0 & $112,500,000$ & 90 & $28,125,000$ & 150 & 60 & 200 & TS \\
\hline
\end{tabular}




\begin{tabular}{|c|c|c|c|c|c|c|c|c|c|}
\hline \multirow[b]{2}{*}{ Country } & \multirow[b]{2}{*}{ Reference climate } & \multicolumn{2}{|c|}{ Collector area $\left[\mathrm{m}^{2}\right]$} & \multirow{2}{*}{$\begin{array}{c}\text { Share of } \\
\text { DHW- } \\
\text { SFH [\%] }\end{array}$} & \multirow{2}{*}{$\begin{array}{c}\text { Number of } \\
\text { systems } \\
\text { DHW-SFH }\end{array}$} & \multicolumn{2}{|c|}{ Hot water } & \multirow{2}{*}{$\begin{array}{c}\text { Storage } \\
\text { capacity } \\
{[1]}\end{array}$} & \multirow[b]{2}{*}{$\begin{array}{l}\text { Sys- } \\
\text { tem }\end{array}$} \\
\hline & & $\begin{array}{c}\text { for single } \\
\text { system }\end{array}$ & $\begin{array}{l}\text { total of DHW- } \\
\text { SFH } 2008\end{array}$ & & & $\begin{array}{c}\text { demand } \\
{[\mathrm{l} / \mathrm{d}]}\end{array}$ & $\begin{array}{l}\text { temp. } \\
{\left[{ }^{\circ} \mathrm{C}\right]}\end{array}$ & & \\
\hline Cyprus & Nicosia & 4.0 & 658,886 & 82 & 164,722 & 150 & 60 & 200 & TS \\
\hline Czech Republic & Praha & 6.0 & 140,260 & 99 & 23,377 & 150 & 60 & 300 & PS \\
\hline Denmark & Copenhagen & 4.0 & 355,223 & 86 & 88,806 & 150 & 60 & 200 & PS \\
\hline Estonia & Tallin & 4.0 & 1,891 & 100 & 473 & 150 & 60 & 200 & PS \\
\hline Finland & Helsinki & 4.0 & 23,238 & 95 & 5,809 & 150 & 60 & 200 & PS \\
\hline France & Paris & 4.0 & $1,324,440$ & 75 & 331,110 & 150 & 60 & 200 & PS \\
\hline Germany & Würzburg & 6.0 & $6,603,618$ & 64 & $1,100,603$ & 150 & 60 & 300 & PS \\
\hline Greece & Athens & 4.0 & $3,792,600$ & 98 & 948,150 & 150 & 60 & 200 & TS \\
\hline Hungary & Budapest & 6.0 & 52,177 & 99 & 8,696 & 150 & 60 & 300 & PS \\
\hline India & Neu-Delhi & 4.0 & $1,771,837$ & 70 & 442,959 & 150 & 60 & 200 & TS \\
\hline Ireland & Dublin & 4.0 & 67,649 & 89 & 16,912 & 150 & 60 & 200 & PS \\
\hline Israel & Jerusalem & 4.0 & $3,697,420$ & 98 & 924,355 & 150 & 60 & 200 & TS \\
\hline Italy & Bologna & 4.0 & $1,449,600$ & 100 & 362,400 & 150 & 60 & 200 & PS \\
\hline Japan & Tokyo & 4.0 & $5,638,698$ & 96 & $1,409,675$ & 150 & 60 & 200 & TS \\
\hline Jordan & Amman & 4.0 & 714,452 & 80 & 178,613 & 150 & 60 & 200 & TS \\
\hline South Korea & Seoul & 4.0 & 771,030 & 54 & 192,758 & 150 & 60 & 200 & PS \\
\hline Lativa & Riga & 4.0 & 6,864 & 100 & 1,716 & 150 & 60 & 200 & PS \\
\hline Lithuania & Vilnius & 4.0 & 4,118 & 100 & 1,030 & 150 & 60 & 200 & PS \\
\hline Luxembourg & Luxembourg & 4.0 & 21,600 & 100 & 5,400 & 150 & 60 & 200 & PS \\
\hline Macedonia & Skopje & 4.0 & 19,331 & 85 & 4,833 & 150 & 60 & 200 & PS \\
\hline Malta & Luqa & 4.0 & 33,946 & 100 & 8,486 & 150 & 60 & 200 & PS \\
\hline Mexico & Mexico City & 4.0 & 150,481 & 28 & 37,620 & 150 & 60 & 200 & PS \\
\hline Namibia & Windhoek & 4.0 & 2,967 & 44 & 742 & 150 & 60 & 200 & TS \\
\hline Netherlands & Amsterdam & 3.0 & 284,629 & 83 & 94,876 & 110 & 60 & 100 & PDS \\
\hline New Zealand & Wellington & 4.0 & 121,606 & 95 & 30,401 & 170 & 60 & 300 & PS \\
\hline Norway & Oslo & 6.0 & 11,863 & 98 & 1,977 & 150 & 60 & 300 & PS \\
\hline Poland & Warsaw & 6.0 & 227,279 & 65 & 37,880 & 150 & 60 & 300 & PS \\
\hline Portugal & Lisbon & 4.0 & 335,190 & 95 & 83,797 & 150 & 60 & 200 & PS \\
\hline Romania & Bucharest & 4.0 & 74,496 & 100 & 18,624 & 150 & 60 & 200 & PS \\
\hline Slovak Republic & Bratislava & 6.0 & 107,246 & 100 & 17,874 & 150 & 60 & 300 & PS \\
\hline Slovenia & Ljubjana & 6.0 & 101,839 & 83 & 16,973 & 150 & 60 & 300 & PS \\
\hline South Africa & Johannesburg & 4.0 & 275,682 & 100 & 68,920 & 150 & 60 & 200 & TS \\
\hline Spain & Madrid & 4.0 & 902,016 & 58 & 225,504 & 150 & 60 & 200 & PS \\
\hline Sweden & Gothenburg & 6.0 & 27,600 & 10 & 4,600 & 150 & 60 & 300 & PS \\
\hline Switzerland & Zürich & 6.0 & 361,740 & 67 & 60,290 & 150 & 60 & 300 & PS \\
\hline Taiwan & Taipei & 4.0 & $1,667,709$ & 98 & 416,927 & 150 & 60 & 200 & TS \\
\hline Thailand & Bangkok & 4.0 & 76,742 & 100 & 19,185 & 150 & 60 & 200 & TS \\
\hline Tunisia & Tunis & 4.0 & 277,498 & 97 & 69,374 & 150 & 60 & 200 & TS \\
\hline Turkey & Ankara & 4.0 & $9,892,224$ & 93 & $2,473,056$ & 150 & 60 & 200 & TS \\
\hline United Kingdom & London & 4.0 & 370,483 & 100 & 92,621 & 150 & 60 & 200 & PS \\
\hline United States & Indianapolis, Los Angeles & 6.0 & $2,724,910$ & 100 & 454,152 & 150 & 60 & 200 & PS \\
\hline Uruguay & Montevideo & 4.0 & 4,861 & 100 & 1,215 & 150 & 60 & 200 & PS \\
\hline Zimbabwe & Harare & 4.0 & 17,316 & 100 & 4,329 & 150 & 60 & 200 & PS \\
\hline TOTAL & & & $165,151,927$ & & $40,270,500$ & & & & \\
\hline & 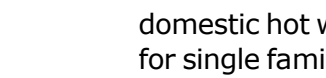 & houses & & & & & & (ImI & stem \\
\hline PS: & pumped syste & & & Aux & ary heatir & vice: 0 & il boiler & & \\
\hline
\end{tabular}

Table 9: Domestic hot water reference systems for single family houses and the total collector area in operation in 2008 (flat-plate and evacuated tube collectors)

Next, Figure 39 shows the hydraulic scheme used for the energy calculation for all pumped solar thermal systems and Figure $\mathbf{4 0}$ refers to the thermosiphon systems.

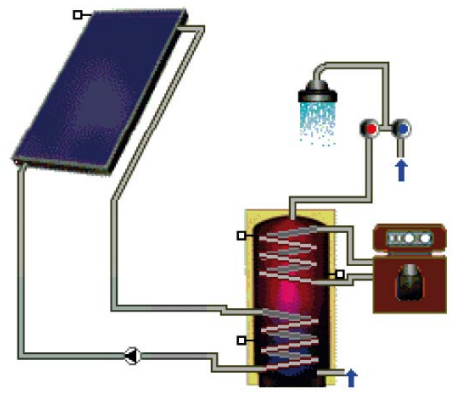

Figure 39 : Hydraulic scheme of the DHW pumped reference system

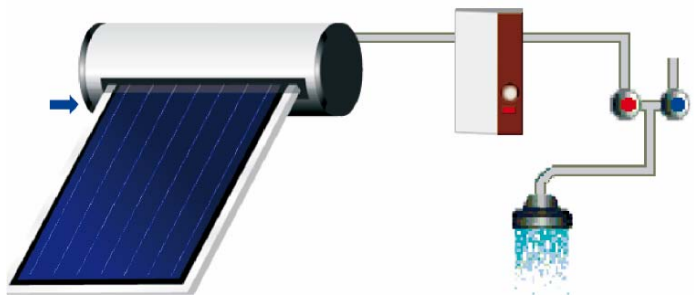

Figure 40 : Hydraulic scheme of the DHW thermosiphon reference system 
For the Chinese thermosiphon systems, the same reference system was used but instead of flat plate collectors as shown in Figure $\mathbf{4 0}$ a typical vacuum tube collector was used for the simulation.

\subsubsection{Solar domestic hot water systems for multi-family houses, hotels and district heating}

The market share in the Table 10 refers to the total capacity in operation of flat-plate and evacuated tube collectors at the end of 2008 for each country. It must be pointed out that the market share of the new installed capacity in the year 2008 can differ greatly from the total market share.

\begin{tabular}{|c|c|c|c|c|c|c|c|c|c|}
\hline \multirow[b]{2}{*}{ Country } & \multirow[b]{2}{*}{$\begin{array}{l}\text { Reference } \\
\text { climate }\end{array}$} & \multicolumn{2}{|c|}{ Collector area $\left[\mathrm{m}^{2}\right]$} & \multirow{2}{*}{$\begin{array}{c}\text { Share } \\
\text { of DHW- } \\
\text { MFH [\%] }\end{array}$} & \multirow{2}{*}{$\begin{array}{l}\text { Number of } \\
\text { systems } \\
\text { DHW-MFH }\end{array}$} & \multicolumn{2}{|c|}{ Hot water } & \multirow{2}{*}{$\begin{array}{c}\text { Storage } \\
\text { capacity } \\
{[1]}\end{array}$} & \multirow[b]{2}{*}{$\begin{array}{l}\text { Sys- } \\
\text { tem }\end{array}$} \\
\hline & & $\begin{array}{l}\text { for single } \\
\text { system }\end{array}$ & $\begin{array}{l}\text { total of DHW- } \\
\text { MFH } 2008\end{array}$ & & & $\begin{array}{l}\text { demand } \\
{[\mathrm{l} / \mathrm{d}]}\end{array}$ & temp. & & \\
\hline Albania & Tirana & 50 & 42,638 & 74 & 853 & 2000 & 60 & 2500 & PS \\
\hline Australia & Sydney & 50 & 38,362 & 2 & 767 & 2000 & 60 & 2500 & PS \\
\hline Austria & Graz & 50 & 334,024 & 10 & 6,680 & 2000 & 60 & 2500 & PS \\
\hline Brazil & Brasília & 50 & 488,653 & 14 & 9,773 & 2000 & 60 & 2500 & PS \\
\hline Bulgaria & Sofia & 50 & 8,717 & 29 & 174 & 2000 & 60 & 2500 & PS \\
\hline Canada & Montreal & 50 & 4,836 & 5 & 97 & 2000 & 60 & 2500 & PS \\
\hline China & Shanghai & 50 & $10,625,000$ & 9 & 212,500 & 2000 & 60 & 2500 & PS \\
\hline Cyprus & Nicosia & 50 & 144,634 & 18 & 2,893 & 2000 & 60 & 2500 & PS \\
\hline Czech Republic & Praha & 50 & 1,417 & 1 & 28 & 2000 & 60 & 2500 & PS \\
\hline Denmark & Copenhagen & 50 & 53,696 & 13 & 1,074 & 2000 & 60 & 2500 & PS \\
\hline Finland & Helsinki & 50 & 1,223 & 5 & 24 & 2000 & 60 & 2500 & PS \\
\hline France & Paris & 50 & 176,592 & 10 & 3,532 & 2000 & 60 & 2500 & PS \\
\hline Germany & Würzburg & 50 & 257,954 & 3 & 5,159 & 2000 & 60 & 2500 & PS \\
\hline Greece & Athens & 50 & 74,323 & 2 & 1,486 & 2000 & 60 & 2500 & PS \\
\hline Hungary & Budapest & 50 & 527 & 1 & 11 & 2000 & 60 & 2500 & PS \\
\hline India & Neu-Delhi & 50 & 759,359 & 30 & 15,187 & 2000 & 60 & 2500 & PS \\
\hline Ireland & Dublin & 50 & 3,040 & 4 & 61 & 2000 & 60 & 2500 & PS \\
\hline Israel & Jerusalem & 50 & 75,458 & 2 & 1,509 & 2000 & 60 & 2500 & PS \\
\hline Japan & Tokyo & 50 & 117,473 & 2 & 2,349 & 2000 & 60 & 2500 & PS \\
\hline Jordan & Amman & 50 & 171,468 & 20 & 3,429 & 2000 & 60 & 2500 & PS \\
\hline South Korea & Seoul & 50 & 656,804 & 46 & 13,136 & 2000 & 60 & 2500 & PS \\
\hline Macedonia & Skopje & 50 & 3,411 & 15 & 68 & 2000 & 60 & 2500 & PS \\
\hline Mexico & Mexico City & 50 & 382,112 & 72 & 7,642 & 2000 & 60 & 2500 & PS \\
\hline Namibia & Windhoek & 50 & 3,236 & 48 & 65 & 2000 & 60 & 2500 & PS \\
\hline Netherlands & Amsterdam & 50 & 40,656 & 12 & 813 & 2000 & 60 & 2500 & PDS \\
\hline New Zealand & Wellington & 50 & 6,400 & 5 & 128 & 2000 & 60 & 2500 & PS \\
\hline Norway & Oslo & 50 & 121 & 1 & 2 & 2000 & 60 & 2500 & PS \\
\hline Poland & Warsaw & 50 & 104,898 & 30 & 2,098 & 2000 & 60 & 2500 & PS \\
\hline Portugal & Lisbon & 50 & 17,642 & 5 & 353 & 2000 & 60 & 2500 & PS \\
\hline Slovenia & Ljubjana & 50 & 2,454 & 2 & 49 & 2000 & 60 & 2500 & PS \\
\hline Spain & Madrid & 50 & 622,080 & 40 & 12,442 & 2000 & 60 & 2500 & PS \\
\hline Sweden & Gothenburg & 50 & 39,744 & 15 & 795 & 2000 & 60 & 2500 & PS \\
\hline Switzerland & Zürich & 50 & 43,193 & 8 & 864 & 2000 & 60 & 2500 & PS \\
\hline Taiwan & Taipei & 50 & 28,117 & 2 & 562 & 2000 & 60 & 2500 & PS \\
\hline aautoTunisia & Tunis & 50 & 8,582 & 3 & 172 & 2000 & 60 & 2500 & PS \\
\hline Turkey & Ankara & 50 & 744,576 & 7 & 14,892 & 2000 & 60 & 2500 & PS \\
\hline TOTAL & & & $16,083,421$ & & 321,668 & & & & \\
\hline
\end{tabular}

DHW-MFH: domestic hot water systems for multi family houses, PS: pumped system, Auxiliary heating device: oil boiler

Table 10: Domestic hot water reference systems for multi-family houses, hotels and district heating and the total collector area in operation in 2008 (flat-plate and evacuated tube collectors)

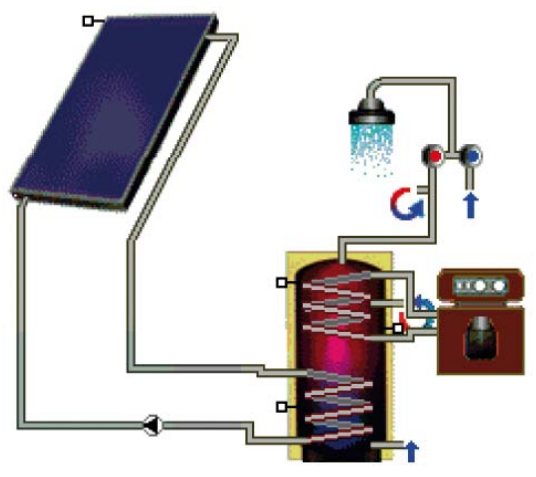

Figure 41: Hydraulic scheme of the DHW system for multi family houses 


\subsubsection{Solar combi-systems for domestic hot water and space heating for single family houses}

The market share of combi-systems in the following table refers to the total capacity in operation of flat-plate and evacuated tube collectors at the end of 2008 for each country. It must be pointed out that the market share of the new installed capacity in the year 2008 can differ significantly from the total market share. The reference system is designed for a single-family house with $140 \mathrm{~m}^{2}$ gross area.

\begin{tabular}{|c|c|c|c|c|c|c|c|c|}
\hline Country & $\begin{array}{l}\text { Reference } \\
\text { climate }\end{array}$ & $\begin{array}{c}\text { Collectc } \\
\text { for single } \\
\text { system }\end{array}$ & $\begin{array}{c}\text { or area }\left[\mathrm{m}^{2}\right] \\
\text { total of DHW- } \\
\text { SFH } 2008\end{array}$ & $\begin{array}{l}\text { Share of CS } \\
(2010)[\%]\end{array}$ & $\begin{array}{c}\text { Number } \\
\text { of CS } \\
2008 \\
\end{array}$ & $\begin{array}{c}\text { Storage } \\
\text { capacity } \\
{[1]}\end{array}$ & $\begin{array}{c}\text { Space heat } \\
\text { demand } \\
{\left[\mathrm{kWh} / \mathrm{m}^{2} \cdot \mathrm{a}\right]}\end{array}$ & ติ๊ \\
\hline Austria & Graz & 15.00 & 935,268 & 28 & 62,351 & 2,000 & 80 & PS \\
\hline China & Shanghai & 12.00 & $1,875,000$ & 2 & 156,250 & 800 & 80 & PS \\
\hline Denmark & Copenhagen & 12.00 & 4,130 & 1 & 344 & 800 & 100 & PS \\
\hline France & Paris & 15.00 & 264,888 & 15 & 17,659 & 1,000 & 80 & PS \\
\hline Germany & Würzburg & 12.00 & $3,456,582$ & 34 & 288,048 & 800 & 80 & PS \\
\hline Ireland & Dublin & 12.00 & 5,321 & 7 & 443 & 1,000 & 100 & PS \\
\hline Japan & Tokyo & 12.00 & 117,473 & 2 & 9,789 & 800 & 80 & PS \\
\hline Namibia & Windhoek & 12.00 & 539 & 8 & 45 & 800 & 8 & PS \\
\hline Netherlands & Amsterdam & 6.00 & 17,146 & 5 & 2,858 & 500 & 80 & PS \\
\hline Norway & Oslo & 12.00 & 121 & 1 & 10 & 1,000 & 100 & PS \\
\hline Poland & Warsaw & 12.00 & 17,483 & 5 & 1,457 & 1,000 & 100 & PS \\
\hline Slovenia & Ljubjana & 12.00 & 18,405 & 15 & 1,534 & 800 & 80 & PS \\
\hline Spain & Madrid & 12.00 & 31,104 & 2 & 2,592 & 800 & 80 & PS \\
\hline Sweden & Gothenburg & 12.00 & 198,720 & 75 & 16,560 & 1,000 & 100 & PS \\
\hline Switzerland & Zürich & 12.00 & 134,978 & 25 & 11,248 & 800 & 80 & PS \\
\hline TOTAL & & & $7,077,158$ & & 571,189 & & & \\
\hline
\end{tabular}

CS = Combi Systems: systems for the supply of hot water and space heating, PS: pumped system, Auxiliary heating device: oil boiler;

Table 11: Reference systems for combi-systems for single-family houses and the percentage of the total collector area in operation (flat-plate and evacuated tube collectors)

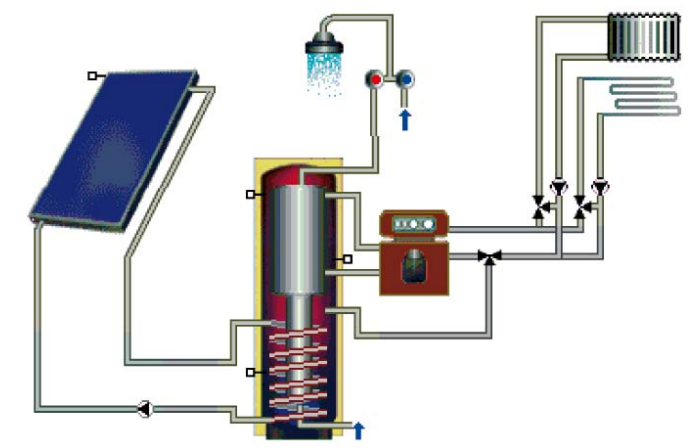

Figure 42: Hydraulic scheme of the solar combi reference system 


\subsection{Reference collector}

7.2.1 Data of the reference absorber for swimming pool heating

$\eta=0.85$

$\mathrm{a} 1=20\left[\mathrm{~W} / \mathrm{m}^{2} \mathrm{~K}\right]$

$\mathrm{a} 2=0.1\left[\mathrm{~W} / \mathrm{m}^{2} \mathrm{~K}^{2}\right]$

7.2.2 Data of the reference collector for all other applications except for China

$\eta=0.8$

$\mathrm{a} 1=3.69\left[\mathrm{~W} / \mathrm{m}^{2} \mathrm{~K}\right]$

$\mathrm{a} 2=0.007\left[\mathrm{~W} / \mathrm{m}^{2} \mathrm{~K}^{2}\right]$

7.2.3 Data of the Chinese reference vacuum tube collector

$\eta=0.74$

$\mathrm{a} 1=2.5\left[\mathrm{~W} / \mathrm{m}^{2} \mathrm{~K}\right]$

$\mathrm{a} 2=0.013\left[\mathrm{~W} / \mathrm{m}^{2} \mathrm{~K}^{2}\right]$

\subsection{Reference climates}

\begin{tabular}{|l|l|c|c|}
\hline Country & $\begin{array}{l}\text { Reference } \\
\text { climate }\end{array}$ & $\begin{array}{r}\text { Horizontal } \\
\text { irradiation Go } \\
{\left[\mathrm{kWh} / \mathrm{m}^{2 * a} \text { ] }\right.}\end{array}$ & $\begin{array}{c}\text { Avg. Outside } \\
\text { air temp. } \\
{\left[{ }^{\circ} \mathrm{C}\right]}\end{array}$ \\
\hline Albania & Tirana & $1,604.3$ & 13.5 \\
\hline Australia & Sydney & $1,674.0$ & 18.1 \\
\hline Austria & Graz & $1,126.0$ & 9.2 \\
\hline Barbados & Grantley Adams & $2,016.3$ & 27.4 \\
\hline Belgium & Brussels & 971.1 & 10.0 \\
\hline Brazil & Brasília & $1,792.5$ & 22.0 \\
\hline Bulgaria & Sofia & $1,187.5$ & 10.1 \\
\hline Canada & Montreal & $1,351.4$ & 6.9 \\
\hline Chile & Santiago de Ch. & $1,752.7$ & 14.5 \\
\hline China & Shanghai & $1,281.9$ & 17.1 \\
\hline Cyprus & Nicosia & $1,885.5$ & 19.9 \\
\hline Czech Republic & Praha & 998.4 & 7.9 \\
\hline Denmark & Copenhagen & 989.4 & 8.1 \\
\hline Estonia & Tallin & 960.2 & 5.3 \\
\hline Finland & Helsinki & 948.0 & 4.6 \\
\hline France & Paris & $1,112.4$ & 11.0 \\
\hline Germany & Würzburg & $1,091.3$ & 9.5 \\
\hline Greece & Athens & $1,584.6$ & 18.5 \\
\hline Hungary & Budapest & $1,198.7$ & 11.0 \\
\hline India & Neu-Delhi & $1,960.5$ & 24.7 \\
\hline Ireland & Dublin & 948.7 & 9.5 \\
\hline Israel & Jerusalem & $2,198.0$ & 17.3 \\
\hline Italy & Bologna & $1,419.0$ & 14.3 \\
\hline Japan & Tokyo & $1,175.2$ & 16.7 \\
\hline Jordan & Amman & $2,145.4$ & 17.9 \\
\hline South Korea & Seoul & $1,161.1$ & 12.7 \\
\hline Latvia & Riga & 991.2 & 6.3 \\
\hline & & & \\
\hline & & & \\
\hline
\end{tabular}

\begin{tabular}{|c|c|c|c|}
\hline Country & $\begin{array}{l}\text { Reference } \\
\text { climate }\end{array}$ & $\begin{array}{c}\text { Horizontal } \\
\text { irradiation Go } \\
{\left[\mathrm{kWh} / \mathrm{m}^{2 *} \mathrm{a}\right]}\end{array}$ & $\begin{array}{c}\text { Avg. Outside } \\
\text { air temp. } \\
{\left[{ }^{\circ} \mathrm{C}\right]}\end{array}$ \\
\hline Lithuania & Vilnius & $1,001.2$ & 6.2 \\
\hline Luxembourg & Luxembourg & $1,037.4$ & 8.4 \\
\hline Macedonia & Skopje & $1,380.8$ & 12.5 \\
\hline Malta & Luqa & $1,901.9$ & 18.7 \\
\hline Mexico & Mexico City & $1,706.3$ & 16.6 \\
\hline Namibia & Windhoek & 2363 & 21.0 \\
\hline Netherlands & Amsterdam & 999.0 & 10.0 \\
\hline New Zealand & Wellington & $1,401.2$ & 13.6 \\
\hline Norway & Oslo & 971.1 & 5.8 \\
\hline Poland & Warsaw & $1,024.2$ & 8.1 \\
\hline Portugal & Lisbon & $1,686.4$ & 17.4 \\
\hline Romania & Bucharest & $1,324.3$ & 10.6 \\
\hline Slovak Rep. & Bratislava & $1,213.8$ & 10.3 \\
\hline Slovenia & Ljubjana & $1,114.6$ & 9.8 \\
\hline South Africa & Johannesburg & $2,075.1$ & 15.6 \\
\hline Spain & Madrid & $1,643.5$ & 15.5 \\
\hline Sweden & Gothenburg & 933.9 & 7.2 \\
\hline Switzerland & Zürich & $1,093.8$ & 9.6 \\
\hline Taiwan & Taipei & $1,372.2$ & 20.8 \\
\hline Thailand & Bangkok & $1,764.8$ & 29.1 \\
\hline Tunisia & Tunis & $1,808.2$ & 19.3 \\
\hline Turkey & Ankara & $1,700.9$ & 12.0 \\
\hline UK & London & 942.6 & 12.0 \\
\hline United & $\begin{array}{l}\text { Indianapolis } \\
\text { Los Angeles }\end{array}$ & $\begin{array}{l}1,492.3 \\
1,799.8\end{array}$ & $\begin{array}{l}11.3 \\
17.2\end{array}$ \\
\hline Uruguay & Montevideo & $1,534.2$ & 15.9 \\
\hline Zimbabwe & Harare & $2,017.1$ & 18.9 \\
\hline
\end{tabular}

Table 12: Reference climates for the 53 countries surveyed 


\subsection{Population data}

\begin{tabular}{|l|r|}
\hline Country & $\mathbf{2 0 0 8}$ \\
\hline Albania & $3,619,778$ \\
\hline Australia & $21,007,310$ \\
\hline Austria & $8,205,533$ \\
\hline Barbados & 283,498 \\
\hline Belgium & $10,403,951$ \\
\hline Brazil & $196,342,587$ \\
\hline Bulgaria & $7,262,675$ \\
\hline Canada & $33,212,696$ \\
\hline Chile & $16,454,143$ \\
\hline China & $1,317,065,677$ \\
\hline Cyprus & $1,066,817$ \\
\hline Czech Republic & $10,220,911$ \\
\hline Denmark & $5,484,723$ \\
\hline Estonia & $1,307,605$ \\
\hline Finland & $5,244,749$ \\
\hline France & $64,057,790$ \\
\hline Germany & $82,369,548$ \\
\hline Greece & $10,722,816$ \\
\hline Hungary & $9,930,915$ \\
\hline
\end{tabular}

\begin{tabular}{|l|r|}
\hline Country & $\mathbf{2 0 0 8}$ \\
\hline India & $1,140,566,211$ \\
\hline Ireland & $4,156,119$ \\
\hline Israel & $7,112,359$ \\
\hline Italy & $58,145,321$ \\
\hline Japan & $127,288,419$ \\
\hline Jordan & $6,132,625$ \\
\hline South Korea & $48,379,392$ \\
\hline Latvia & $2,245,423$ \\
\hline Lithuania & $3,565,205$ \\
\hline Luxembourg & 486,006 \\
\hline Macedonia & $2,061,315$ \\
\hline Malta & 403,532 \\
\hline Mexico & $109,955,400$ \\
\hline Namibia & $2,088,669$ \\
\hline Netherlands & $16,645,313$ \\
\hline New Zealand & $4,173,460$ \\
\hline Norway & $4,644,457$ \\
\hline Poland & $38,500,696$ \\
\hline Portugal & $10,676,910$ \\
\hline
\end{tabular}

\begin{tabular}{|l|r|}
\hline Country & $\mathbf{2 0 0 8}$ \\
\hline Romania & $22,246,862$ \\
\hline Slovak Republic & $5,455,407$ \\
\hline Slovenia & $2,007,711$ \\
\hline South Africa & $48,782,755$ \\
\hline Spain & $40,491,051$ \\
\hline Sweden & $9,045,389$ \\
\hline Switzerland & $7,581,520$ \\
\hline Taiwan & $22,920,946$ \\
\hline Thailand & $65,578,534$ \\
\hline Tunisia & $10,383,577$ \\
\hline Turkey & $75,793,836$ \\
\hline United Kingdom & $60,943,912$ \\
\hline United States & $304,059,724$ \\
\hline Uruguay & $3,477,778$ \\
\hline Zimbabwe & $11,350,111$ \\
\hline & \\
\hline$\sum$ Solar Thermal & $4,081,609,667$ \\
\hline World Statistic & $6,681,112,529$ \\
\hline$\sum$ Inhabitants world & \\
\hline
\end{tabular}

Data source: International Data Base of the U.S. Census Bureau http://www.census.gov/ipc/www/idb/country.php

Table 13: Inhabitants of the 53 surveyed countries in alphabetic order

\begin{tabular}{|l|r|r|}
\hline & Inhabitants & Share \\
\hline United States+Canada & $337,272,420$ & $8.3 \%$ \\
\hline Japan & $127,288,419$ & $3.1 \%$ \\
China & $1,317,065,677$ & $32.3 \%$ \\
\hline Europe & $584,993,796$ & $14.3 \%$ \\
\hline Australia + New Zealand & $25,180,770$ & $0.6 \%$ \\
\hline
\end{tabular}

\begin{tabular}{|l|r|r|}
\hline & Inhabitants & Share \\
\hline Asia & $1,277,445,083$ & $31.3 \%$ \\
\hline Central and South America & $326,513,406$ & $8.0 \%$ \\
\hline Africa & $72,605,112$ & $1.8 \%$ \\
\hline Middle East & $13,244,984$ & $0.3 \%$ \\
\hline TOTAL & $\mathbf{4 , 0 8 1 , 6 0 9 , 6 6 7}$ & $\mathbf{1 0 0} \%$ \\
\hline
\end{tabular}

Data source: International Data Base of the U.S. Census Bureau http://www.census.gov/ipc/www/idb/country.php

Middle East: $\quad$ Israel, Jordan

Africa: Namibia, South Africa, Tunisia, Zimbabwe

Central \& South America: Barbados, Brazil, Chile, Mexico, Uruguay

Asia: $\quad$ India, South Korea, Taiwan, Thailand

Europe: $\quad$ EU 27, Albania, Macedonia, Norway, Overseas Dep. of France, Switzerland, Turkey

Table 14: Inhabitants per economic region

\subsection{Market data of the previous years}

The data presented in Chapters 3 through 5 were originally collected in square meters. Through an agreement of international experts the collector areas of these solar thermal applications have been converted and are shown in installed capacity.

Making the installed capacity of solar thermal collectors comparable with that of other energy sources, solar thermal experts from seven countries agreed upon a methodology to convert installed collector area into solar thermal capacity.

The methodology was developed during a meeting with IEA SHC Programme and major solar thermal trade associations in Gleisdorf, Austria in September 2004. The represented associations from Austria, Canada, Germany, the Netherlands, Sweden and the United States as well as the European Solar Thermal Industry Federation (ESTIF) and the IEA SHC Programme agreed to use a factor of $0.7 \mathrm{~kW}$ th $/ \mathrm{m} 2$ to derive the nominal capacity from the area of installed collectors.

Nevertheless, solar thermal collectors are traditionally quoted in square meters and therefore Table 15 and Table 16 provide the 2006 and 2007 data in $\mathrm{m}^{2}$ as well as the total installed collector area in 2007 (Table 17). 
The following tables containing data for 2006 and 2007 may deviate from data provided in the previous reports. Due to more detailed investigations in several countries updated data were provided. The main differences to previous years result from either corrected country specific data (e.g. China, India) or from solar thermal collector replacements in the total number of systems installed (e.g. China, Israel, USA).

\begin{tabular}{|c|c|c|c|c|c|c|}
\hline \multirow{2}{*}{ Country } & \multicolumn{3}{|c|}{ Water Collectors } & \multicolumn{2}{|c|}{ Air Collectors } & \multirow{2}{*}{ TOTAL $\left[\mathrm{m}^{2}\right]$} \\
\hline & Unglazed* & Glazed* & evacuated tube* & Unglazed* & Glazed* & \\
\hline Albania & & 7,960 & 76 & & & 8,036 \\
\hline Australia & 550,000 & 156,000 & 15,000 & & & 721,000 \\
\hline tlparAustria & 6,935 & 289,745 & 2,924 & & & 299,604 \\
\hline Barbados & & 2,731 & & & & 2,731 \\
\hline Belgium & 8,828 & 31,267 & 4,369 & & & 44,464 \\
\hline Brazil & 57,873 & 434,331 & & & & 492,204 \\
\hline Bulgaria & & 2,200 & & & & 2,200 \\
\hline Canada & 36,292 & 1,312 & 712 & 23,441 & 38 & 61,795 \\
\hline Chile & & 7,043 & & & & 7,043 \\
\hline China & & 900,000 & $17,100,000$ & & & $18,000,000$ \\
\hline Cyprus & & 60,000 & & & & 60,000 \\
\hline Czech Republic & 6,000 & 18,490 & 3,540 & & & 28,030 \\
\hline Denmark & 1,600 & 28,500 & 1,000 & & 7,000 & 38,100 \\
\hline Estonia & & 300 & & & & 300 \\
\hline Finland & & 3,400 & & & & 3,400 \\
\hline France & 6,000 & 284,000 & 11,000 & & & 301,000 \\
\hline Germany & 30,000 & $1,350,000$ & 150,000 & & 5,400 & $1,535,400$ \\
\hline Greece & & 249,000 & & & & 249,000 \\
\hline Hungary & & 1,000 & & & & 1,000 \\
\hline India & & 340,410 & & & 5,000 & 345,410 \\
\hline Ireland & & 4,100 & 900 & & & 5,000 \\
\hline Israel & 3,800 & 222,000 & & & & 225,800 \\
\hline Italy & 3,650 & 155,798 & 26,552 & & & 186,000 \\
\hline Japan & & 262,665 & 1,382 & 17,436 & & 281,483 \\
\hline Jordan & & 7,666 & 3,600 & & & 11,266 \\
\hline Korea & & 29,043 & & & & 29,043 \\
\hline Latvia & & 1,200 & & & & 1,200 \\
\hline Lithuania & & 600 & & & & 600 \\
\hline Luxembourg & & 2,500 & & & & 2,500 \\
\hline Macedonia & & 2,118 & 36 & & & 2,154 \\
\hline Malta & & 4,500 & & & & 4,500 \\
\hline Mexico & 29,029 & 67,735 & & & & 96,764 \\
\hline Namibia & & 1,720 & & & & 1,720 \\
\hline Netherlands & 24,419 & 14,937 & & & & 39,356 \\
\hline New Zealand & 600 & 9,600 & 3,350 & & & 13,550 \\
\hline Norway & & 700 & 100 & & & 800 \\
\hline Poland & 150 & 35,150 & 6,250 & & & 41,550 \\
\hline Portugal & & 28,300 & & & & 28,300 \\
\hline Romania & & 5,500 & & & & 5,500 \\
\hline Slovak Republic & & 7,700 & 800 & & & 8,500 \\
\hline Slovenia & & 6,300 & 600 & & & 6,900 \\
\hline South Africa & 65,100 & 13,800 & & & & 78,900 \\
\hline Spain & & 161,875 & 13,125 & & & 175,000 \\
\hline Sweden & 13,416 & 19,825 & 8,713 & & & 41,954 \\
\hline Switzerland** & 8,953 & 50,355 & 1,508 & 1,000 & & 61,816 \\
\hline Taiwan & & 113,646 & 8,554 & & & 122,200 \\
\hline Thailand & & 6,800 & & & & 6,800 \\
\hline Tunisia & & 34,526 & 474 & & & 35,000 \\
\hline Turkey & & 700,000 & & & & 700,000 \\
\hline United Kingdom & & 14,000 & 14,000 & & & 28,000 \\
\hline United States & $1,335,656$ & 119,380 & 5,110 & 0 & 557 & $1,460,703$ \\
\hline Uruguay & & 1,429 & & & & 1,429 \\
\hline Zimbabwe & & 86 & & & & 86 \\
\hline TOTAL & $2,188,301$ & $6,273,241$ & $17,383,675$ & 41,877 & 17,995 & $25,905,090$ \\
\hline
\end{tabular}

* If no data is given: no reliable database for this collector type available

** Unglazed air collectors in Switzerland: this is a very simple site-built system for hay drying

Table 15: Collector area installed in 2006 [m²/a] 


\begin{tabular}{|c|c|c|c|c|c|c|}
\hline \multirow{2}{*}{ Country } & \multicolumn{3}{|c|}{ Water Collectors } & \multicolumn{2}{|c|}{ Air Collectors } & \multirow{2}{*}{ TOTAL $\left[\mathrm{m}^{2}\right]$} \\
\hline & Unglazed* & Glazed* & evacuated tube* & Unglazed* & Glazed* & \\
\hline Albania & & 9,290 & 88 & & & 9,378 \\
\hline Australia & 576,000 & 203,000 & 3,000 & & & 782,000 \\
\hline IparAustria & 8,662 & 277,620 & 3,399 & & & 289,681 \\
\hline Barbados & & 2,731 & & & & 2,731 \\
\hline Belgium & 8,828 & 37,000 & 5,000 & & & 50,828 \\
\hline Brazil & 97,442 & 475,394 & 350 & & & 573,186 \\
\hline Bulgaria & & 2,500 & & & & 2,500 \\
\hline Canada & 39,879 & 1,462 & 2,385 & 17,056 & 128 & 60,910 \\
\hline Chile & & 7,957 & & & & 7,957 \\
\hline China & & $1,150,000$ & $21,850,000$ & & & $23,000,000$ \\
\hline Cyprus & & 15,000 & 1,000 & & & 16,000 \\
\hline Czech Republic & 6,000 & 18,900 & 6,100 & & & 31,000 \\
\hline Denmark & 600 & 23,000 & 400 & 3,400 & 3,500 & 30,900 \\
\hline Estonia & & 350 & & & & 350 \\
\hline Finland & & 2,100 & 622 & & & 2,722 \\
\hline France & 5,300 & 305,000 & 12,700 & & & 323,000 \\
\hline Germany & 30,000 & 840,000 & 100,000 & & 5,000 & 975,000 \\
\hline Greece & & 279,000 & 4,000 & & & 283,000 \\
\hline Hungary & & 6,000 & 2,000 & & & 8,000 \\
\hline India & & 424,150 & & & 7,000 & 431,150 \\
\hline Ireland & & 14,872 & 4,799 & & & 19,671 \\
\hline Israel & 700 & 301,000 & & & & 301,700 \\
\hline $\begin{array}{l}\text { rarsid6095729 It- } \\
\text { aly }\end{array}$ & 3,650 & 210,000 & 35,000 & & & 248,650 \\
\hline Japan & & 166,223 & 4,051 & & 12,509 & 182,783 \\
\hline Jordan & & 7,666 & 3,600 & & & 11,266 \\
\hline Korea & & 38,700 & & & & 38,700 \\
\hline Lativa & & 1,500 & & & & 1,500 \\
\hline Lithuania & & 700 & & & & 700 \\
\hline Luxembourg & & 3,000 & & & & 3,000 \\
\hline Macedonia & & 1,952 & 200 & & & 2,152 \\
\hline Malta & & 5,500 & & & & 5,500 \\
\hline Mexico & 46,281 & 107,989 & & & & 154,270 \\
\hline Namibia & & 2,810 & 190 & & & 3,001 \\
\hline Netherlands & 27,722 & 19,920 & & & & 47,642 \\
\hline New Zealand & 600 & 11,800 & 5,150 & & & 17,550 \\
\hline Norway & 200 & 720 & 50 & & & 970 \\
\hline Poland & & 47,032 & 21,115 & & & 68,147 \\
\hline Portugal & 618 & 44,483 & 5,696 & & & 50,797 \\
\hline Romania & & 6,500 & & & & 6,500 \\
\hline Slovak Republic & & 15,554 & 9,911 & & & 25,465 \\
\hline Slovenia & & 6,515 & 1,150 & & & 7,665 \\
\hline South Africa & 67,300 & 14,000 & 0 & & & 81,300 \\
\hline Spain & 3,000 & 251,000 & 11,000 & & & 265,000 \\
\hline Sweden & 20,435 & 15,554 & 9,911 & & & 45,900 \\
\hline Switzerland** & 10,320 & 63,022 & 2,554 & 2,000 & & 77,896 \\
\hline Taiwan & & 125,000 & 9,900 & & & 134,900 \\
\hline Thailand & & 8,000 & & & & 8,000 \\
\hline Tunisia & & 39,000 & 1,000 & & & 40,000 \\
\hline Turkey & & 700,000 & & & & 700,000 \\
\hline United Kingdom & & 27,000 & 27,000 & & & 54,000 \\
\hline United States & $1,113,434$ & 142,597 & 22,574 & 0 & 1,393 & $1,279,998$ \\
\hline Uruguay & & 2,857 & & & & 2,857 \\
\hline Zimbabwe & & 171 & & & & 171 \\
\hline TOTAL & $2,066,971$ & $6,483,092$ & $22,165,895$ & 22,456 & 29,530 & $30,767,944$ \\
\hline
\end{tabular}

* If no data is given: no reliable database for this collector type available

** Unglazed air collectors in Switzerland: this is a very simple site-built system for hay drying

Table 16: Collector area installed in 2007 [m²/a] 


\begin{tabular}{|c|c|c|c|c|c|c|}
\hline \multirow{2}{*}{ Country } & \multicolumn{3}{|c|}{ Water Collectors } & \multicolumn{2}{|c|}{ Air Collectors } & \multirow{2}{*}{ TOTAL $\left[\mathrm{m}^{2}\right]$} \\
\hline & Unglazed* & Glazed* & evacuated tube* & Unglazed* & Glazed* & \\
\hline Albania & & 49,930 & 246 & & & 50,176 \\
\hline Australia & $4,070,000$ & $1,660,000$ & 23,000 & & & $5,753,000$ \\
\hline Austria & 608,890 & $2,949,558$ & 42,983 & & & $3,601,431$ \\
\hline Barbados & & 82,794 & & & & 82,794 \\
\hline Belgium & 48,828 & 133,750 & 12,368 & & & 194,946 \\
\hline Brazil & 97,442 & $3,587,499$ & 350 & & & $3,685,291$ \\
\hline Bulgaria & & 27,600 & & & & 27,600 \\
\hline Canada & 665,920 & 81,755 & 4,747 & 129,962 & 191 & $\mathbf{8 8 2}, \mathbf{5 7 5}$ \\
\hline Chile & 1,470 & 9,773 & & & & 11,243 \\
\hline China & & $9,840,547$ & $98,159,453$ & & & $108,000,000$ \\
\hline Cyprus & & 794,749 & 962 & & & 795,710 \\
\hline Czech Republic & 15,230 & 97,090 & 15,490 & & & 127,810 \\
\hline Denmark & 21,370 & 393,860 & 3,400 & 3,400 & 18,750 & 440,780 \\
\hline Estonia & & 1,470 & & & & 1,470 \\
\hline Finland & 500 & 15,583 & 1,302 & & & 17,385 \\
\hline France & 104,500 & $1,416,500$ & 33,000 & & & $1,554,000$ \\
\hline Germany & 750,000 & $7,784,095$ & 863,982 & & & $9,398,077$ \\
\hline Greece & & $3,566,200$ & 6,800 & & & $3,573,000$ \\
\hline Hungary & 2,800 & 41,340 & 2,560 & & & 46,700 \\
\hline India & & $2,150,000$ & & & 17,000 & $2,167,000$ \\
\hline Ireland & & 27,657 & 7,910 & & & 35,567 \\
\hline Israel & 24,200 & $3,734,878$ & & 422 & & $3,759,500$ \\
\hline Italy & 26,270 & 873,520 & 102,860 & & & $1,002,650$ \\
\hline Japan & & $6,824,569$ & 127,069 & 434,371 & 12,509 & $7,398,518$ \\
\hline Jordan & & 840,332 & 7,200 & & & 847,532 \\
\hline Korea & & $1,389,134$ & & & & $1,389,134$ \\
\hline Latvia & & 5,350 & & & & 5,350 \\
\hline Lithuania & & 3,450 & & & & 3,450 \\
\hline Luxembourg & & 18,900 & & & & 18,900 \\
\hline Macedonia & & 19,070 & 200 & & & 19,270 \\
\hline Malta & & 29,360 & & & & 29,360 \\
\hline Mexico & 467,592 & 443,880 & & & & 911,473 \\
\hline Namibia & & 5,979 & 190 & & & 6,169 \\
\hline Netherlands & 343,527 & 329,506 & & & & 673,033 \\
\hline New Zealand & 6,217 & 102,914 & 10,046 & & & 119,177 \\
\hline Norway & 1,600 & 11,220 & 150 & & 1,200 & 14,170 \\
\hline Poland & 1,300 & 197,874 & 36,723 & 3,000 & 2,500 & 241,397 \\
\hline Portugal & 594 & 276,038 & 5,477 & & & 282,109 \\
\hline Romania & & 69,600 & & & & 69,600 \\
\hline Slovak Republic & & 88,304 & 9,911 & & & 98,215 \\
\hline Slovenia & & 115,815 & 1,150 & & & 116,965 \\
\hline South Africa & 628,610 & 247,680 & & & & 876,290 \\
\hline Spain & 3,000 & $1,164,164$ & 45,600 & & & $1,212,764$ \\
\hline Sweden & 80,000 & 223,000 & 29,000 & & & 332,000 \\
\hline Switzerland** & 212,400 & 433,490 & 25,420 & 838,000 & & $1,509,310$ \\
\hline Taiwan & & $1,136,919$ & 118,421 & & & $1,255,340$ \\
\hline Thailand & & 70,000 & & & & 70,000 \\
\hline Tunisia & & 216,523 & 1,477 & & & 218,000 \\
\hline Turkey & & $10,150,000$ & & & & $10,150,000$ \\
\hline United Kingdom & & 277,920 & 27,000 & & & 304,920 \\
\hline United States & $17,072,278$ & $1,918,800$ & 580,729 & 93 & 215,169 & $19,787,070$ \\
\hline Uruguay & & 2,004 & & & & 2,004 \\
\hline Zimbabwe & & 17,121 & 24 & & & 17,145 \\
\hline TOTAL & $25,254,538$ & $65,949,061$ & $100,307,200$ & $1,409,249$ & 267,319 & $193,187,367$ \\
\hline
\end{tabular}

* If no data is given: no reliable database for this collector type available

** Unglazed air collectors in Switzerland: this is a very simple site-built system for hay drying

Table 17: Total collector area in operation at the end of 2007 [ $\left.\mathrm{m}^{2}\right]$ 


\subsection{References to reports and persons that have supplied the data}

The realization of the solar heat worldwide report 2008 was kindly supported by national representatives of the recorded countries.

\begin{tabular}{ll} 
Albania & Edmond M. Hido \\
Australia & Sonja Ott \\
Austria & $\begin{array}{l}\text { Werner Weiss and } \\
\text { Manuela Eberl }\end{array}$ \\
Barbados & \\
Belgium & Marcelo Mesquita \\
Brazil & \\
Bulgaria & Annie Dobrinova P. \\
Canada & Doug McClenahan \\
Chile & Cristian Yanez \\
& Carlos F. C. Faria \\
\hline Cyina & Hu Runqing \\
& Soteris Kalogirou
\end{tabular}

Czech Republic

Denmark

Estonia

Finland

France

Germany

\begin{tabular}{ll} 
& Harald Drück \\
\hline Greece & Vassiliki Drosou
\end{tabular}

Hungary
Albania - EU Energy Efficiency Centre

Renewable Energy |Sustainability Victoria

AEE INTEC

Statistical projection AEE INTEC based on previous data

ESTIF 2009

Gestor do DASOL - Depto. Nac. Aquecimento Solar da ABRAVA

Bulgarian National Section of ISES \& ESTIF 2009

CANMET - Natural Resources Canada

CDT Chile

Marcasolar

Center for Renewable Energy Development Energy Research Institute, NDRC

Cyprus University of Technology; Department of Mechanical Engineering and Materials Sciences and Engineering (personal guessing)

ESTIF 2009

ESTIF 2009

ESTIF 2009

Helsinki University of Technology, Espoo

Motiva Oy

ADEME - Centre de Sophia Antipolis

Fraunhofer ISE (sources: Marktanreizprogramm MAP, GroSolStudy)

ITW- University of Stuttgart (sources: GroSol-Study, dataanalysis from German market incentive programme )

CRES - Centre for Renewable Energy Sources

ESTIF 2009 
India

Ireland

Israel

Italy

Japan

Jordan

Korea

Lativa

Lithuania

Luxembourg

Macedonia

Malta

Mexico

Namibia

Netherlands

New Zealand

Norway

Poland

Portugal

Romania

Slovak Republic
Jaideep Malaviya

C. Palaniappan

Ministry of Non-

Conventional Energy

Sources, Goverment of India

Amanda Barriscale

Asher Vaturi

Valeria Verga

YAMASHITA Noriaki

Nidal Abdalla

Nam-choon Baek

Sanja Popovska-

Vasilevska

Wilfrido Rivera GomezFranco

Kudakwashe Ndhlukula

Reinoud Segers

Fritjof Salvesen

Grzegorz Wiśniewski; Aneta Wiecka

João Farinha Mendes
Jawaharlal Nehru National Solar Mission

Planters Energy Network - PEN

Download Market Assessment report: http://mnes.nic.in/pdf/ greentech-SWH-MarketAssessment-report.pdf

Sustainable Energy Ireland (Grant scheme data; GHS and REHEAT programmes)

ICTAF - Interdisciplinary Center for Technological Analysis and ForecastingTel Aviv University

Associazione Italiana Solare Termico (Assolterm market study [2009])

ISEP - Institute for Sustainable Energy Policies (ISEP, SSDA, METI)

National Energy Research Center (NERC)

Korea Institute of Energy Research (KIER) (source: 2008 statistics of New \& Renewable Energy Supply)

ESTIF 2009

ESTIF 2009

ESTIF 2009

Solar Macedonia, Company Information + Ministry of Economy of Republic of Macedonia

\section{ESTIF 2009}

Universidad Nacional Autonoma de Mexico -

Centro de Investigacion en Energia

Renewable Energy \& Energy Efficiency Institute (REEEI)

Statistics Netherlands

statistical projection AEE INTEC based on previous data

KanEnergi AS

EC BREC Institute for Renewable Energy Ltd.

Unidadede Energia Solar (sources: APISOLAR [Associação Portuguesa da Indústria Solar] and ADENE [Agência para a Energia])

ESTIF 2009

ESTIF 2009 
Slovenia

Tanja Mohorič

$\begin{array}{ll}\text { South Africa } & \text { Dieter Holm } \\ \text { Spain } & \text { Pascual Polo } \\ & \text { Esther Rojas } \\ \text { Sweden } & \text { Jan-Olof Dalenbäck }\end{array}$

Switzerland

Urs Wolfer

Taiwan

K.M. Chung

Thailand

Tunisia

Turkey

United Kingdom

United States

Uruguay

Zimbabwe
Les Nelson

\section{NJEIMI Moncef}

A. Kutay ULKE

Carlos F. C. Faria

Anton Schwarzlmüller
Tanja Mohorič (sources: SSTTP, Slovenian Solar Thermal Technology Platform; University of Ljubljana, Faculty of Mechanical Engineering; Eko fund, Slovenian Environmental Public Fund)

Soltrain, South Africa - country market report

ASIT, Asociación Solar de la Industria Térmica CIEMAT

Jan-Olof Dalenbäck, Svensk solenergi \& CHALMERS University of Technology

Bundesamt für Energie BFE (source: Markterhebung Sonnenergie 2008 SWISSOLAR, Urs Wolfer)

National Cheng Kung University [NCKU research \& development fundation]

statistical projection AEE INTEC

PROSOL - ANME

A. Kutay ULKE [EZINC Metal San. Tic. A.S.]

ESTIF 2009

Solar Energy Industries Association

Energy Information Administration (EIA) [http:// www.eia.doe.gov/cneaf/solar.renewables/page/solarreport/ solar.html]

Cabrera\&Associados/ Mesa Solar

DSH, Soltrain, Zimbabwe - country market report

\subsubsection{Additional literature used}

The following reports and statistics were used in this report.

- European Solar Thermal Industry Federation (ESTIF): Solar Thermal Markets in Europe, Trends and Market Statistics 2008; Belgium - Brussels; May 2009

- Bundesamt für Energie (BFE): Markterhebung Sonnenenergie 2008 - Teilstatistik der Schweizerischen Statistik der erneuerbaren Energien, Switzerland - Bern; August 2009

- Bundesministerium für Verkehr, Innovation und Technologie (BMVIT): Erneuerbare Energie in Österreich Marktentwicklung 2008; Wien; Mai 2009

- Solar Thermal Collector Manufacturing Activities 2008, U.S. Energy Information Administration DOE/EIA, Washington, January 2010; download: http://www.eia.doe.gov/fuelrenewable.html

- SARASIN, Sustainability Report, Solar Energy 2009, Bank Sarasin \& Co. Ltd ("BSC"), Switzerland - Basel, November 2009

- Market Assessment report - Ministry for New and Renewable Energy, Government of India, homepage: http:// mnes.nic.in/; download: http://mnes.nic.in/pdf/greentech-SWH-MarketAssessment-report.pdf

- REN 21: Renewables 2010 Global Status Report, 2010 


\subsection{List of Figures}

Figure 1: $\quad$ Countries represented in this report

Figure 2: Total capacity in operation $\left[\mathrm{GW}_{\mathrm{el}}\right],\left[\mathrm{GW}_{\mathrm{th}}\right] 2009$ and annually energy generated $\left[\mathrm{TWh}_{\mathrm{el}}\right],\left[\mathrm{TWh}_{\mathrm{th}}\right]$. Sources: EPIA, GWEC, EWEA, EGEC, REN21 and IEA SHC 2009

Figure 3: Share of the total collector installations (glazed and unglazed water and air collectors) by economic regions at the end of 2008

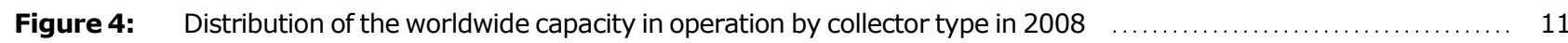

Figure 5: Total capacity of water collectors in operation in the 10 leading countries at the end of $2008 \quad \ldots \ldots \ldots \ldots \ldots \ldots$

Figure 6: Total capacity of glazed flat-plate and evacuated tube collectors in operation at the end of $2008 \quad \ldots \ldots \ldots \ldots \ldots 12$

Figure 7: Total capacity of glazed flat-plate and evacuated tube collectors in operation at the end of 2008 in $\mathrm{kW}_{\text {th }}$ per 1,000 inhabitants

Figure 8: Total capacity of glazed flat-plate and evacuated tube collectors in operation by economic region at the end of 2008

Figure 9: Total capacity of glazed flat-plate and evacuated tube collectors in operation by economic region at the end of 2008 in $\mathrm{kW}_{\text {th }}$ per 1,000 inhabitants

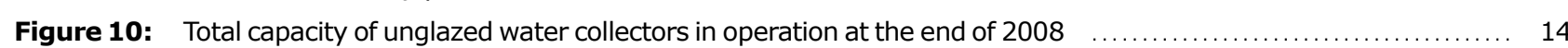

Figure 11: Total capacity of unglazed water collectors in operation at end of 2008 in $\mathrm{kW}_{\text {th }}$ per 1,000 inhabitants $\ldots \ldots \ldots 14$

Figure 12: Total capacity of unglazed collectors in operation by economic region at the end of $2008 \quad \ldots \ldots \ldots \ldots \ldots \ldots \ldots$

Figure 13: Total capacity of unglazed collectors in operation by economic region at the end of 2008 in $\mathrm{kW}_{\text {th }}$ per 1,000 inhabitants

Figure 14: Share of the newly installed capacity of glazed water collectors by economic region in $2008 \quad \ldots \ldots \ldots \ldots \ldots \ldots$

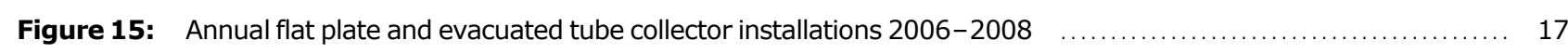

Figure 16: Share of the newly installed capacity of unglazed water collectors by economic region in $2008 \quad \ldots \ldots \ldots \ldots \ldots \ldots$

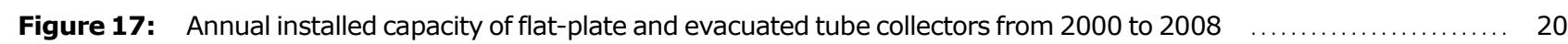

Figure 18: Annually installed capacity of flat-plate and evacuated tube collectors in $\mathrm{kW}_{\text {th }}$ per 1,000 inhabitants from 2000 to 2008

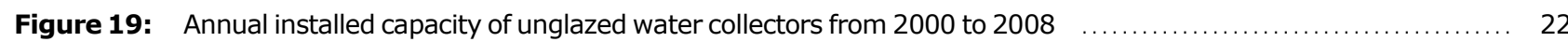

Figure 20: Annual collector yield of glazed flat-plate and evacuated tube collectors in operation by economic region in 2008

Figure 21: Annual collector yield of glazed flat-plate and evacuated tube collectors in operation by economic region at the end of 2008 in kWh per 1,000 inhabitants

Figure 22: Annual collector yield of unglazed collectors in operation by economic region at the end of 2008

Figure 23: Annual collector yield of unglazed collectors in operation by economic region at the end of $2008 \mathrm{in} \mathrm{kWh}$ per 1,000 inhabitants

Figure 24: Annual energy savings in oil equivalent by glazed flat-plate and evacuated tube collectors by economic region at the end of 2008

Figure 25: Annual energy savings in oil equivalent by glazed flat-plate and evacuated tube collectors in operation by economic region at the end of 2008 per 1,000 inhabitants

Figure 26: Annual energy savings in oil equivalent by unglazed collectors by economic region at the end of 2008

Figure 27: Annual energy savings in oil equivalent by unglazed collectors by economic region at the end of 2008 per 1,000 inhabitants

Figure 28: Contribution to $\mathrm{CO}_{2}$ reduction by flat-plate and evacuated tube collectors by economic region in 2008

Figure 29: Contribution to $\mathrm{CO}_{2}$ reduction by flat-plate and evacuated tube collectors by economic region in 2008 per 1,000 inhabitants

Figure 30: Contribution to $\mathrm{CO}_{2}$ reduction by unglazed collectors by economic region in 2008

Figure 31: Contribution to $\mathrm{CO}_{2}$ reduction by unglazed collectors by economic region in 2008 per 1,000 inhabitants 
Figure 32: Distribution of different solar thermal systems by economic region for the total capacity in operation of glazed and evacuated tube collectors in 2008

Figure 33: Distribution of different applications by economic region for the total capacity in operation of glazed and evacuated tube collectors in 2008

Figure 34: Distribution of different applications of the world's top-10-countries related to the total capacity in operation of glazed and evacuated tube collectors in 2008

Figure 35: Distribution of different applications in the European top-10-countries related to the total capacity in operation of glazed and evacuated tube collectors in 2008

Figure 36: Distribution of different applications newly installed in 2008 by economic region for glazed and evacuated tube collectors

Figure 37: Distribution of different applications of the world's top-8-countries related to the newly installed capacity of glazed and evacuated tube collectors in 2008

Figure 38: Hydraulic scheme of the swimming pool reference system

Figure 39: Hydraulic scheme of the DHW pumped reference system

Figure 40: Hydraulic scheme of the DHW thermosiphon reference system

Figure 41: Hydraulic scheme of the DHW system for multi family houses

Figure 42: Hydraulic scheme of the solar combi reference system

\subsection{List of Tables}

Table 1: Total capacity in operation at the end of 2008 [MW

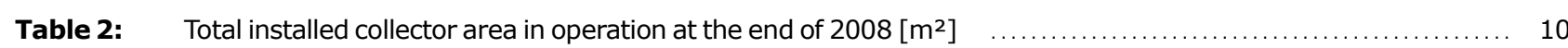

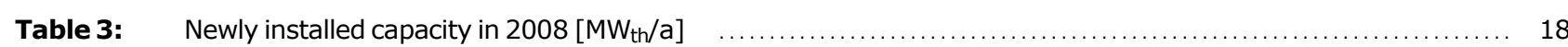

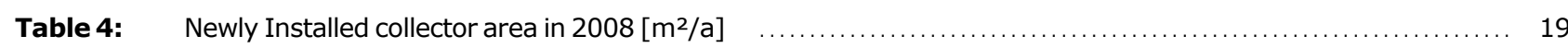

Table 5: Calculated annual collector yield and corresponding oil equivalent as $\mathrm{Wel}_{\mathrm{el}}$ as $\mathrm{CO}_{2}$ reduction of all solar thermal systems (systems for hot water, space heating and swimming pool heating) installed by the end of 2008

Table 6: Calculated annual collector yield and corresponding oil equivalent as $\mathrm{W}_{\mathrm{el}} \mathrm{l}$ as $\mathrm{CO}_{2}$ reduction of solar thermal systems using flat-plate and evacuated tube collectors (for example hot water preparation and space heating, low temperature industrial process heat) installed by the end of 2008

Table 7: Calculated annual collector yield and corresponding oil equivalent as $\mathrm{W}_{\mathrm{el}} \mathrm{l}$ as $\mathrm{CO}_{2}$ reduction of solar thermal systems for swimming pool heating with unglazed collectors installed by the end of 2008

Table 8: Solar thermal swimming pool heating reference systems* and the total collector area in operation in 2008 (unglazed water collectors)

Table 9: Domestic hot water reference systems for single family houses and the total collector area in operation in 2008 (flat-plate and evacuated tube collectors)

Table 10: Domestic hot water reference systems for multi-family houses, hotels and district heating and the total collector area in operation in 2008 (flat-plate and evacuated tube collectors)

Table 11: Reference systems for combi-systems for single-family houses and the percentage of the total collector area in operation (flat-plate and evacuated tube collectors)

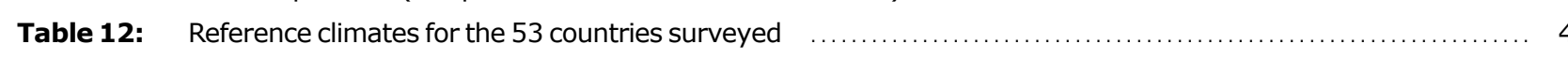

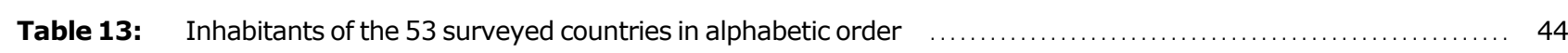

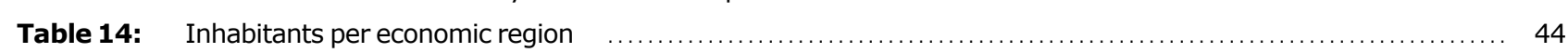

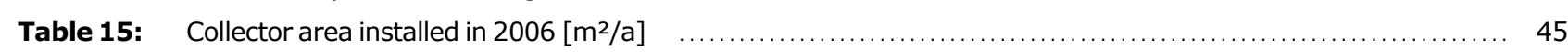

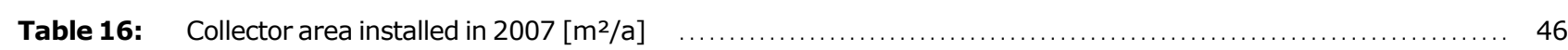

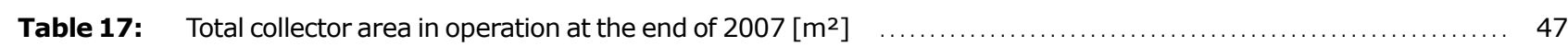

